\title{
Coal Resources
}

\section{of Oklahoma}

GEOLOGICAL SURVEY BULLETIN $1042-$ J

Prepared in cooperation with the

Oklahoma Geological Survey

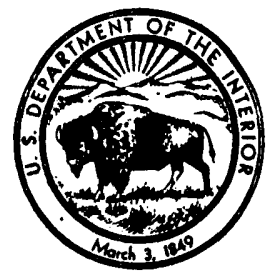




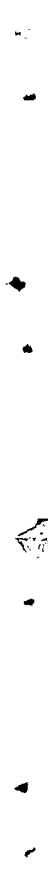

5

1 


\title{
CONTRIBUTIONS TO ECONOMIC GEOLOGY
}

\section{COAL RESOURGES OF OKLAHOMA}

\author{
By James V. A. Trumbull
}

\begin{abstract}
The original reserves of bituminous coal in Oklahoma are estimated at 3,673 million short tons, and the reserves remaining in the ground as of January 1 , 1953, are estimated at 3,245 million short tons. All a vailable information about the location, thickness, and extent of the coal beds of Oklahoma was used in the preparation of this estimate, which includes only coal in beds 14 inches or more thick and within 3,000 feet of the surface.

The Oklahoma coalfield is in the eastern third of the State, and is continuous with the Arkansas coalfield on the east and the southeastern Kansas coalfield on the north. The coal-bearing rocks are of Pennsylvanian (Des Moines and Missouri) age. They are strongly folded in the southern, or McAlester basin, part of the coalfield, where their overall thickness averages about 8,000 feet. The formations into which the rocks of the southern part of the coalfield have been divided are in large part traceable into the northeastern Oklahoma part of the coalfield, but there they are much thinner, are of different character, and have a relatively uniform low westward dip. The names applied to the formations in the two parts of the coalfield are the same, but little progress has been made in correlating the coal beds between the two areas.

Less than 10 coal beds in the southern part of the Oklahoma coalfield are known to be continuous over distances greater than about 15 miles. By far the most important of these are the Lower and Upper Hartshorne beds and the McAlester (Lehigh) bed, which average from 3 to 4 feet in thickness over large areas and together contain over 50 percent of the estimated remaining reserves of the State. Much of this coal, however, is in areas where steep dips have so far restricted or prevented mining.

The Henryetta coal bed in Okmulgee County is close to 3 feet in thickness over large.areas, and it has been extensively mined by both underground and stripping methods.

The coal beds of northeastern Oklahoma are for the most part less than $\mathbf{3 0}$ inches thick, and production from them has been almost entirely by strip mining. The more important and better known of the 14 named coal beds in this part of the State are the Croweburg (Broken Arrow) and the Dawson. Considerable mining has been done in several of the other beds, but because only widely scattered thickness measurements and little outcrop mapping are available, an estimate of the amount of reserves present in them was not attempted.

Sixty-five percent of the estimated remaining reserves of coal in Oklahoma is of high-volatile bituminous rank, 13 percent is of medium-volatile bituminous rank, and 22 percent is of low-volatile bituminous rank. Nearly all coal of medium-volatile and low-volatile bituminous ranks is in Haskell and Le Flore Counties.
\end{abstract}


Twenty-five percent of the estimated remaining reserve is in beds from 14 to 28 inches thick, 39 percent is in beds from 28 to 42 inches thick, and 36 percent is in beds over 42 inches thick. Coal under less than 1,000 feet of overburden makes up 58 percent of the estimate, coal in the 1,000- to 2,000-foot overburden category makes up 25 percent, and coal in the 2,000- to 3,000-foot overburden category makes up 17 percent. Because of the great amount of accurate information needed to delineate strippable coal deposits, no estimates of strippable coal reserves could be prepared. A breakdown of the remaining reserves based on the relative abundance of the information on which the estimates are based shows that 17 percent is classed as measured reserves, 49 percent is classed as indicated reserves, and 34 percent is classed as inferred reserves. The unusually low percentages of coal in thin beds and in the inferredreserve category is due to the frequent proximity of the 3,000-foot overburden cutoff line to the outcrop in the southern part of the field, to known variability in bed thickness in many of the thinner beds, and to inadequate information on which to base estimates of the amount of coal in the thinner beds of northeastern Oklahoma.

The total reported production of coal in Oklahoma from the beginning of mining in 1873 to the end of 1952 is about 166 million tons, of which slightly less than 17 percent was strip mined. The amount of coal produced by strip mining has increased from 13 percent of 1930 production to 60 percent of 1952 production. In 1952, 45 percent of Oklahoma's coal production was used in the manufacture of coke.

The amount of coal originally present in mined-out areas and rendered unminable because of the future need of barrier pillars around presently abandoned mines is estimated at 427 million tons. Comparison of this figure with the total recorded production of $\mathbf{1 6 6 . 4 5}$ million tons indicates that overall recoverability in mining in Oklahoma has been about 39 percent. This unusually low figure is in large part the result of the prevalent high dips of many of the more important coal beds and of the need of leaving unusually wide barrier pillars downdip below flooded mines.

One or more lignite beds of Cretaceous age occur in Cimarron County, at the extreme western end of the Oklahoma panhandle; coal of Pennsylvanian age is present south of the Arbuckle Mountains in Carter County in south-central Oklahoma. Little detailed information about these deposits is available; but it is thought that they are not extensive, and no estimates of the reserves have been made.

\section{INTRODUCTION}

The present report on the coal resources of Oklahoma has been prepared by the Geological Survey in cooperation with the Oklahoma Geological Survey as part of a program to reappraise the coal reserves of the United States. It is based on a study of all available information concerning the location, thickness, extent, and rank of the coal beds in the State. In addition to showing the quantity and distribution of coal in the State as now known, it is intended to provide a convenient summary of the sources of detailed information, and to point out areas where additional detailed information is needed.

As estimated by use of the definitions, procedures, and assumptions outlined in the next section of this report, the original reserves of 
coal in Oklahoma total 3,673 million short tons, and the reserves remaining in the ground as of January 1, 1953, total 3,245 million short tons: (See table 1.)

TABLE 1.-Summary of estimated reserves of coal in Oklahoma

[In millions of short tons]

\begin{tabular}{|c|c|c|c|}
\hline Rank of coal & $\begin{array}{l}\text { Original } \\
\text { reserves }\end{array}$ & $\begin{array}{c}\text { Mined and } \\
\text { lost in mining }\end{array}$ & $\begin{array}{l}\text { Remaining } \\
\text { reserves as of } \\
\text { Jan. 1, 1953 }\end{array}$ \\
\hline $\begin{array}{l}\text { High-volatile bituminous... } \\
\text { Medium-volatile bituminous } \\
\text { Low-volatile bituminous }\end{array}$ & $\begin{array}{r}2,466.27 \\
459.45 \\
747.10\end{array}$ & $\begin{array}{r}351.73 \\
29.37 \\
46.23\end{array}$ & $\begin{array}{r}2,114.54 \\
430.08 \\
700.87\end{array}$ \\
\hline Total & $3,672.82$ & 427. 33 & $3,245.49$ \\
\hline
\end{tabular}

Although this new estimate is markedly smaller than earlier estimates, it is based conservatively only on factual information now available, and thus should have immediate practical usefulness. The estimate will probably be increased in the future as additional mapping and exploratory work is done and the results used to prepare another estimate.

The Oklahoma coalfield (fig. 37) lies in the eastern part of the State at the intersection of several major north-south and east-west railroads. Although production of coal has declined in recent years, Oklahoma coal has qualities that are useful in making coke, and a continuing demand for coal for this purpose may be expected. In 1952 , about 45 percent of the total Oklahoma production was thus used in Texas, Utah, and California. Reserves of low- and mediumvolatile bituminous coal, which have particular usefulness in the manufacture of coke, are concentrated in Haskell and Le Flore Counties. The distribution of the estimated remaining reserves by rank, county, and coal bed is summarized in table 2 , and these and other relationships are shown graphically in figures 38 and 39.

The complete distribution of the estimated remaining reserves by county, bed, rank, overburden thickness, bed thickness, and reliability category is shown in table 8 (p. 372). Table 7 (p. 371) serves as an index to table 8 and shows the bed and rank of coal occurring in each county.

A small percentage of Oklahoma's coal reserves occurs in thick beds (fig. $38 B$ ), and a large percentage occurs under 1,000 to 3,000 feet of overburden (fig. $38 \mathrm{C}$ ). This is a direct result of the mode of occurrence of the coal beds of Oklahoma, but the unusually small percentage of coal in thin beds (fig. $38 B$ ) and in the inferred-reserves 


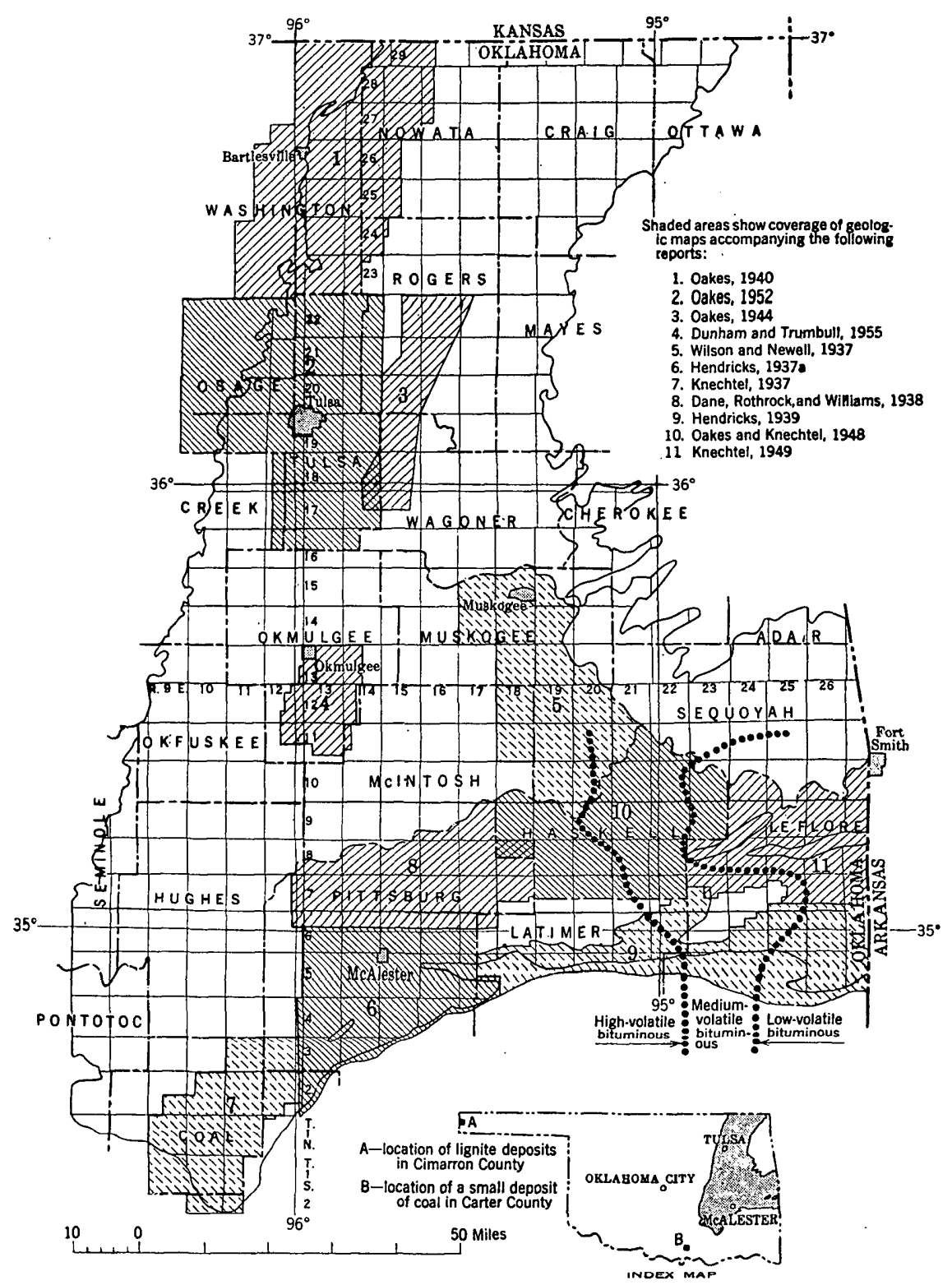

Figure 37.-Map of the coal-bearing parts of Oklahoma showing rank of ${ }_{n}$ coal ${ }_{\star}$ and areas covered by detalled geologic reports. 

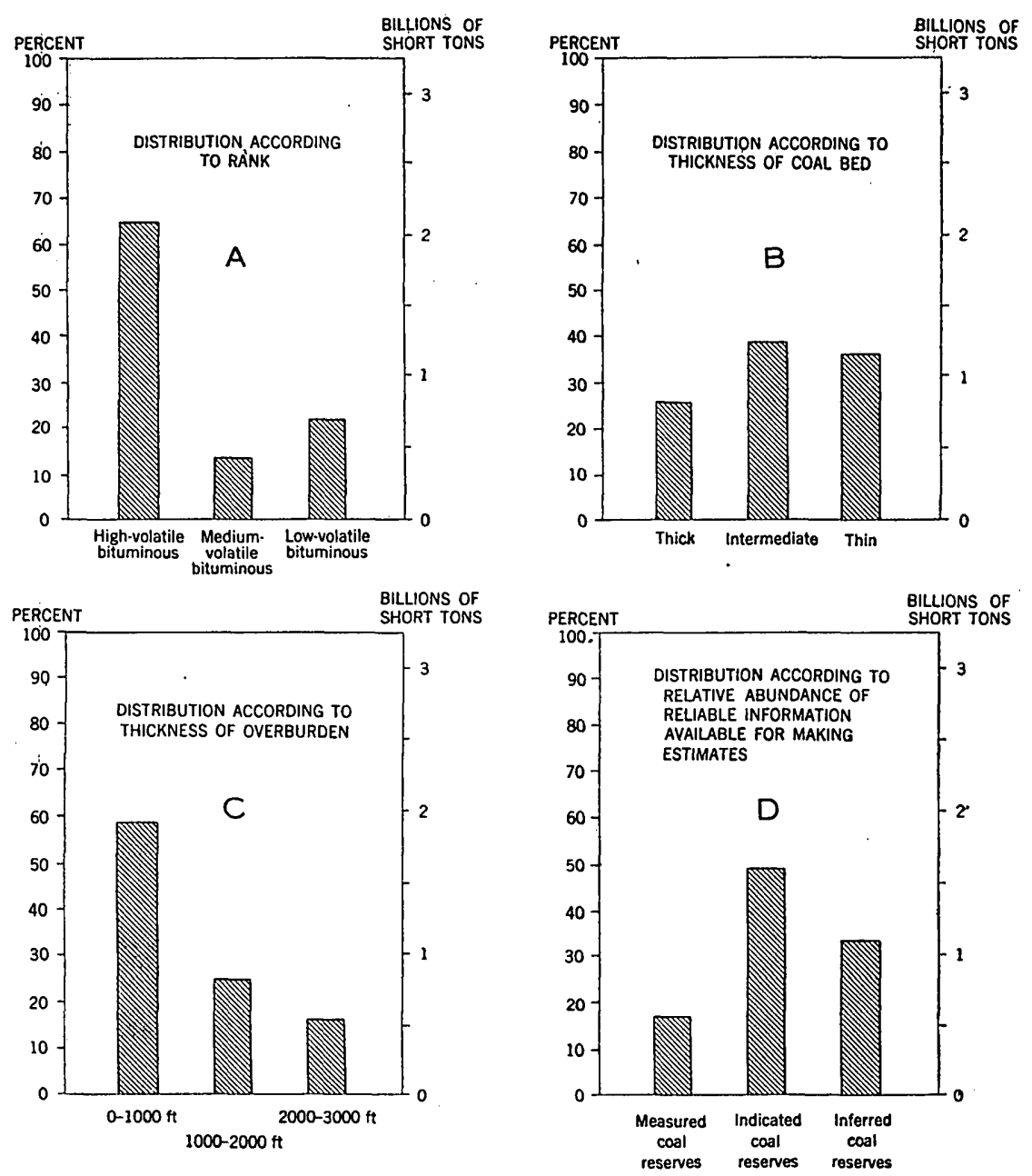

Figure 38.-Distribution of estimated remaining coal reserves of Oklahoma according to categories of $(A)$ rank, $(B)$ thickness of bed, $(C)$ thickness of overburden, and $(D)$ abundance of reliable data.

category (fig. $38 D$ ) are the result of a combination of the following factors:

1. Numerous thin coal beds are present throughout the Oklahoma coalfield, and they are especially numerous in northeastern Oklahoma. Because these thin beds are less inviting to mining operations, less prospecting, mapping, and exploratory work has been done on them than on the thicker beds. Because of insufficient data, reserve estimates for many of these beds over broad areas have not been prepared, even though some of them are known or thought to be more than 14 inches thick at some places. 


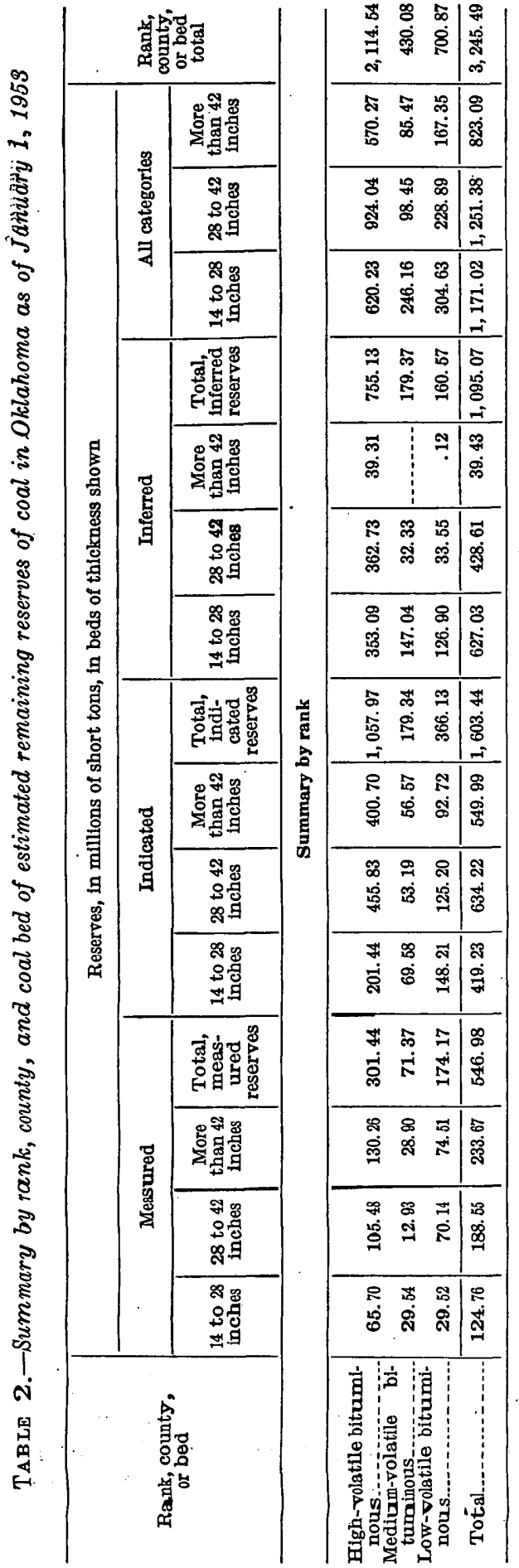

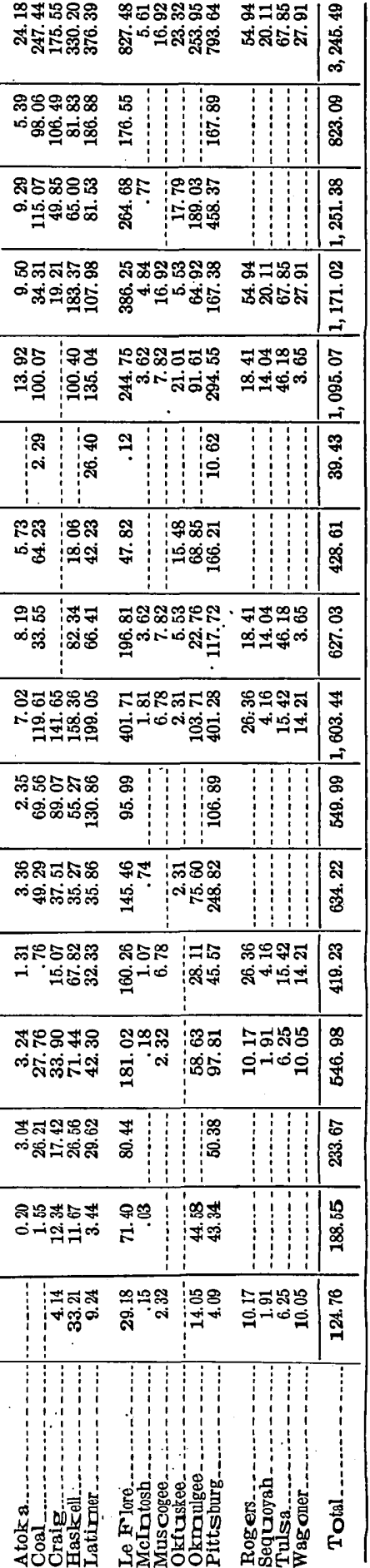




\begin{tabular}{|c|c|c|c|c|c|}
\hline 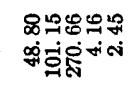 & 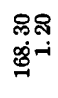 & 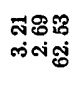 & 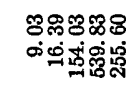 & 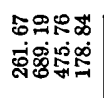 & \&্ষ \\
\hline & $\begin{array}{ll}\overrightarrow{0} \\
0 \\
\infty\end{array}$ & & 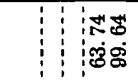 & 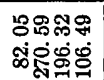 & $\mid \begin{array}{l}8 \\
\approx \\
\infty \\
\infty\end{array}$ \\
\hline 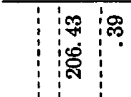 & $\begin{array}{l:}\text { Na } \\
\end{array}$ & & 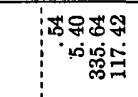 & 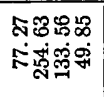 & 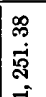 \\
\hline 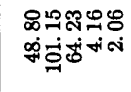 & 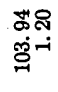 & 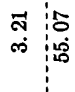 & 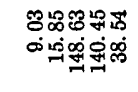 & 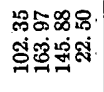 & 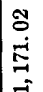 \\
\hline 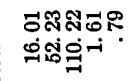 & $\mathbb{\infty}_{\infty}^{\infty}$ & 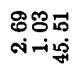 & 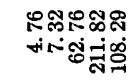 & 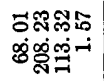 & $\begin{array}{l}5 \\
\text { s. } \\
0 \\
0\end{array}$ \\
\hline & & & & 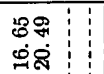 & $\begin{array}{l}\text { ma } \\
\dot{m}\end{array}$ \\
\hline & \begin{tabular}{l:l}
\multirow{\infty}{*}{} & \\
$\stackrel{\sim}{\sim}$ &
\end{tabular} & & స: & 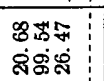 & $\begin{array}{l}\overrightarrow{6} \\
\dot{a}\end{array}$ \\
\hline 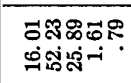 & कร. & & 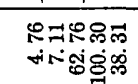 & 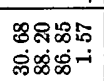 & ஜ \\
\hline 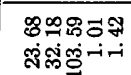 & 落品 & & 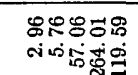 & 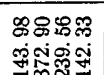 & \$ै \\
\hline & & & & 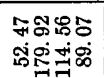 & 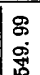 \\
\hline : & 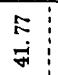 & : & : & 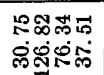 & สิ \\
\hline 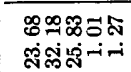 & $\begin{array}{l}\text { Fi } \\
\text { if }\end{array}$ & ชิ: & 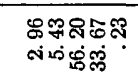 & $\begin{array}{l}908 \% \\
2981 \\
808021\end{array}$ & 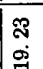 \\
\hline 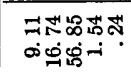 & 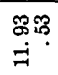 & $\begin{array}{l:l}\infty \\
\infty\end{array}$ & 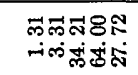 & 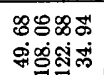 & $\begin{array}{l}\infty \\
0 \\
0\end{array}$ \\
\hline & 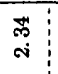 & & 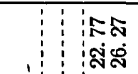 & 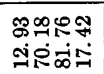 & . \\
\hline 峁 & 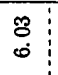 & & 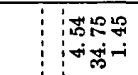 & 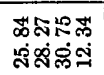 & $\begin{array}{l}\stackrel{\leftrightarrow}{2} \\
\stackrel{\infty}{\infty}\end{array}$ \\
\hline 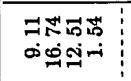 & 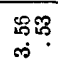 & $\begin{array}{l:l}\infty \\
\infty\end{array}$ & 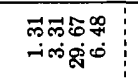 & 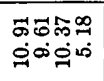 & $\begin{array}{l}8 \\
\text { i }\end{array}$ \\
\hline 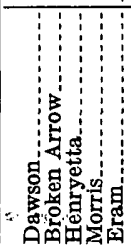 & 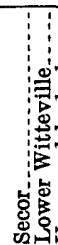 & 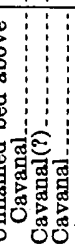 & 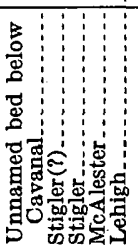 & 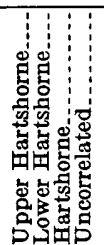 & : \\
\hline
\end{tabular}



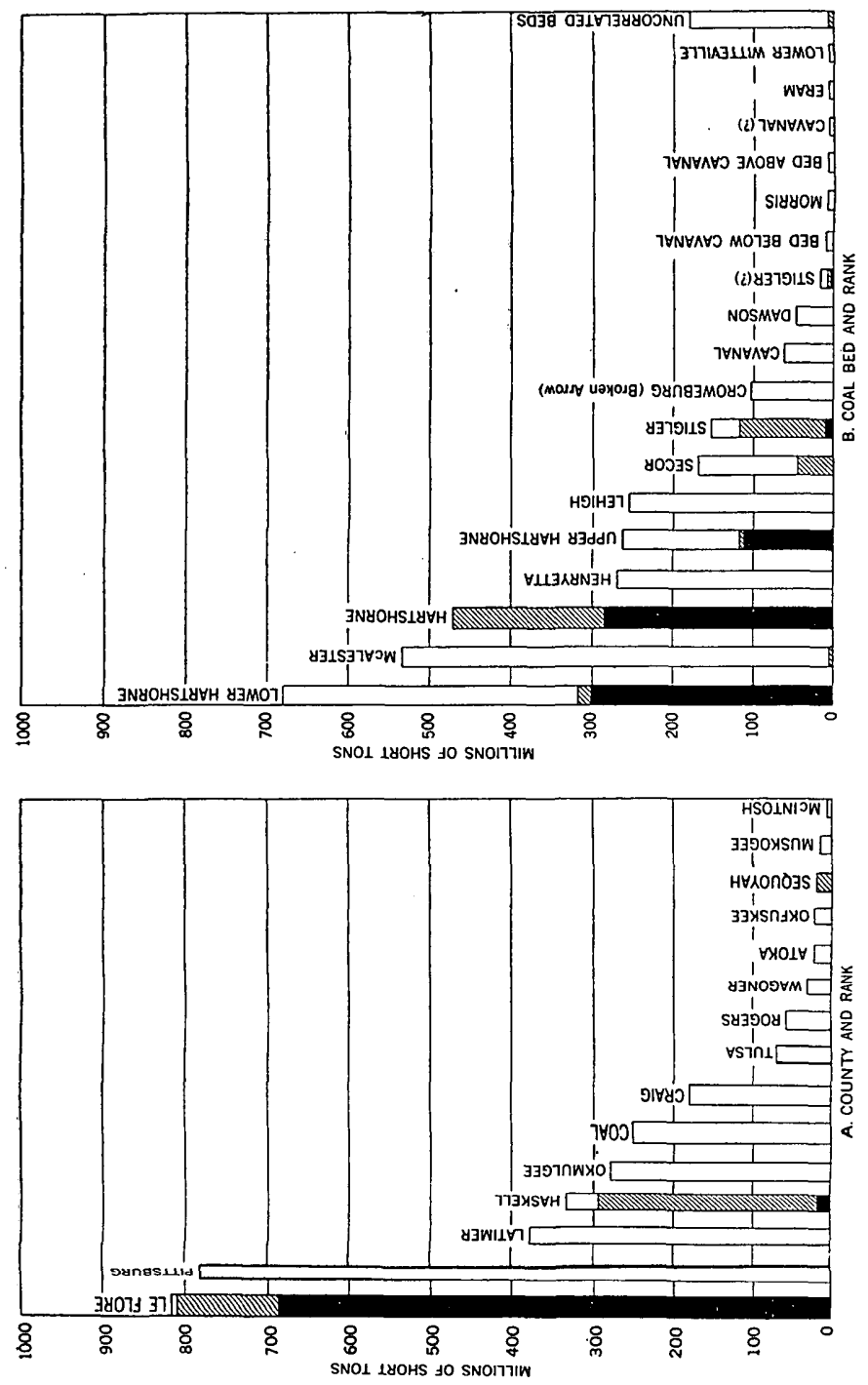
2. Furthermore, some of the coal beds for which it has been possible to calculate reserve estimates are known at many places to be thinner than the 14-inch minimum bed thickness established as a lower cutoff point for inclusion in this reserve estimate. This knowledge has in general prevented the construction of large semicircular areas of inferred reserves that might otherwise have been based on the observed thicknesses of more than 14 inches. Examples of this may be seen on the map of the Broken Arrow and Dawson beds, plate 17. Several of the areas of reserves shown there might have established the presence of much larger areas of inferred reserves had it not been known that the coal bed was thinner than 14 inches between them.

3 . In much of the southern part of the Oklahoma coalfield, welldeveloped large-scale folding (fig. 41) has resulted in large portions of the thicker coal beds being below the 3,000-foot overburden limit of this estimate. In addition to making the total reserve estimate low, that fact has acted differentially to reduce the amount of inferred reserves in the estimate, and also the amount of coal in the thin and intermediate thickness categories. This is because the known presence of thick coal along and behind the outcrop is usually the reason for including in a reserve estimate very large amounts of coal in the inferred-reserve category at some distance behind the outcrop. These inferred reserves of coal, usually judged in the absence of specific information to be thinner than that along the outcrop, have to some extent been omitted from this estimate because they are more than 3,000 feet below the surface.

The estimate of the coal reserves of Oklahoma presented in this report is much smaller than the previously accepted total figure. The reasons for this difference are discussed in detail under "Comparison with other estimates." In general, it may be said that much of the information about the location, thickness, and extent of coal beds in Oklahoma that was used in the preparation of this report was not available when the earlier estimate was prepared. Thus the previous estimate was necessarily based to a large extent on assumptions about the thickness and continuity of the coal beds. The present estimate has been based more directly and conservatively on known measurements, and no estimates have been included for several areas where information is still meager or lacking.

\section{SOURCE OF INFORMATION}

Most of the basic information used in the preparation of this summary report was taken from recent detailed publications of the U. S. Geological Survey and the Oklahoma Geological Survey. The titles and the areas covered by these detailed reports are shown in figure 37 . Additional information was obtained from many older published 
reports and from unpublished manuscript material, files, and openfile reports of the two organizations. The Henryetta mining district in southern Okmulgee County was mapped in detail in connection with this study. The present report includes data derived from that investigation, though the complete report on the Henryetta district is published separately (Dunham and Trumbull, 1955).

Much detailed information derived from measurements on the outcrop and in mines and drill holes was obtained from independent geologists, mining engineers, and officials of mining companies operating in the State. The work of Dr. Carl C. Branson, of the University of Oklahoma, and a number of graduate students working under his direction was the only source of information about the geology and coal beds of a major part of northeastern Oklahoma. In addition, some of the statistical and analytical material included is taken from publications of the U. S. Bureau of Mines and the Department of Chief Mine Inspector, State of Oklahoma.

\section{ACKNOWLEDGMENTS}

Many individuals and organizations contributed time, information, and advice during the preparation of this report. Independent mining engineers and representatives of nearly all the coal-mining companies operating in the State generously permitted the use of mine maps, drill-hole data, and other information. Their names are too numerous to list here, but their cooperation was invaluable. Particular thanks for information and cooperation are due to Dr. C. C. Branson, director, and Malcolm C. Oakes and John H. Warren, of the Oklahoma Geological Survey, at Norman; and to H. B. Lindeman and A. M. Dinsmore, of the U. S. Geological Survey, at McAlester.

Graduate students whose theses on file at the library of the University of Oklahoma have provided information on northeastern Oklahoma include R. B. Austin, L. P. Chrisman, C. D. Claxton, B. K. Crumpley, Clarence Lohman Jr., J. T. Lontos, F. R. Stewart, and J. L. Tillman.

\section{METHODS OF ESTIMATING RESERVES}

Any estimate of the coal reserves of a large area is necessarily based on many assumptions as to the thickness, extent, and correlation of the coal beds. Such an estimate is of value to the reader only to the extent that the definitions and procedures used are explained and understood, and it is of value for comparison with estimates for other areas only if these definitions and procedures are as similar to those used in other estimates as local conditions will permit. The criteria and methods used in preparing this report are briefly described below. They are similar to those used in other State summaries recently published by the Geological Survey. 


\section{CLASSIFICATION ACCORDING TO CHARACTERISTICS OF THE COAL}

Characteristics considered in calculating coal reserves are the rank of the coal, the weight of the coal, the thickness of the coal beds, and the thickness of the overburden.

Rank of coal.--In the United States the rank of coal is determined according to the standard classification of the American Society for Testing Materials, which is reproduced as table 3. Oklahoma coal, except for a small amount of lignite of Cretaceous age in Cimarron County, at the extreme west end of the panhandle of the State, ranges in rank from high-volatile $C$ bituminous to low-volatile bituminous. The amount and proportion of each rank of coal in the State are shown in figure $38 \mathrm{~A}$.

TABLE 3.-Classification of coals by rank ${ }^{1}$

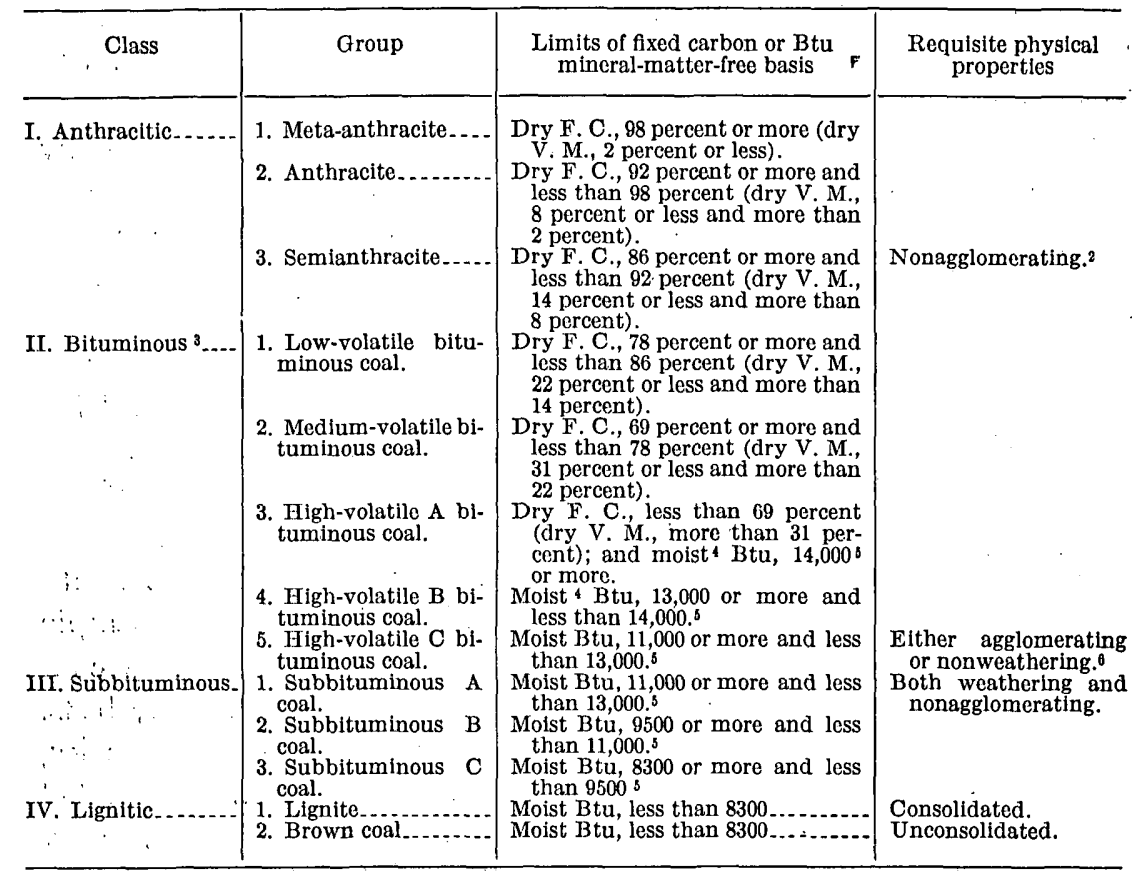

Legend: F. C. $=$ Fixed carbon. V. M. $=$ Volatile matter. Btu $=$ British thermal units.

1 This classiflcation does not include a few coals which have unusual physical and chemical properties and which come within the limits of fixed carbon or Btu. of the high-volatile bituminous and subbituminous ranks. All of these coals either contain less than 48 percent dry, mineral-matter-free fixed carbon or have more than 15,500 moist, mineral-matter-free Btu.

2 If agglomerating, classify in low-volatile group of the bituminous class.

8 It is recognized that there may be noncaking varieties in each group of the bituminous class.

- Moist Btu refers to coal containing its natural bed mojsture but not including visible water on the surface of the coal.

${ }_{3}$ Coals having 69 percent or more fixed carbon on the dry, mineral-matter-free basis shall be classifled according to fixed carbon, regardless of $\mathrm{Btu}$.

B.There are three varieties of coal in the high-volatile $\mathrm{C}$ bituminous coal group, namely, Variety 1 , agglomerating and nonweathering; Variety 2, agglomerating and weathering; Varlety 3, nonagglomerating and nonweathering.

$$
425537-57-3
$$


The reserve estimates contained in this report have been calculated separately for coals of high-volatile bituminous, medium-volatile bituminous, and low-volatile bituminous ranks. The approximate position of the lines dividing coal of these three ranks is shown in figure 37. These lines were located by first plotting the sources of all samples for which reliable analyses were available on a base map at a scale of 1 inch $=2$ miles. Next, the percentage of fixed carbon as determined by each of these analyses was converted from the asreceived basis to the dry, mineral-matter-free basis by the use of the approximation formula (American Society for Testing Materials, 1939, p. 5), and the resulting values were plotted at the proper points on the base map. Contouring of these numerical values, employing detailed mathematical interpolation, established the rank boundaries shown in this report. This determination, though by no means accurate in detail or final, and subject to revision as new analyses are made, is thought to be the best possible on the basis of analyses now available.

Most of the analyses used in the rank determination were made by the U. S. Bureau of Mines after February 1913, and bear sample numbers higher than 16,100; analyses made before that time and bearing lower sample numbers were not made under strictly uniform conditions. Some of the analyses made by the Oklahoma Geological Survey in cooperation with the School of Chemical Engineering of the University of Oklahoma (Moose and Searle, 1929) were used for mines or localities where no Bureau analyses were available. No analysis was used if there was doubt as to the exact location of the point sampled, and no attempt was made to determine the boundaries. of subranks within the high-volatile bituminous rank. Analytical data were used irrespective of the bed from which the analyzed sample was taken; beds for which no analyses were available were considered to be of the rank indicated by analyses of other nearby beds.

For purposes of dividing the reserve estimate into rank categories, the curved lines dividing the three ranks of coal were approximated by a series of straight lines, which often coincided with the nearest township boundary line. Little real inaccuracy is introduced by this approximation, for the points between which the exact position of the dividing lines was interpolated were usually several miles apart.

Weight of coal.-Coal in Oklahoma was assumed to have a specific gravity of 1,32 , which corresponds to a weight of 1,800 tons per acre foot. This figure accords closely with the average specific gravity of bituminous coal with low to moderate ash elsewhere in the United States.

Thickness of beds.-In order to present as much detailed information as possible, the estimates of coal reserves in this report follow 
Geological Survey practice in being separated into three bed-thickness groups, designated thin, intermediate, and thick. For bituminous coal, beds 14 to 28 inches thick are classed as thin, those from 28 to 42 inches are classed as intermediate, and those more than 42 inches are classed as thick. The amount and proportion of the coal resources of Oklahoma that falls within each of these bed thickness: categories are shown in figure $38 \mathrm{~B}$. Although coal beds less than 14 inches thick have been mined on a very small scale in Oklahoma, there are no data for estimating the minable reserves of this thin coal.

Thickness of overburden.-The coal reserve estimates in this report are further divided into 3 categories according to whether the thickness of the overburden on the coal is less than 1,000 feet, 1,000 to 2,000 feet, or 2,000 to 3,000 feet. Coal at depths greater than 3,000 feet is not included. The occurrence of known coal reserves at depths greater than 1,000 feet in Oklahoma is limited to the folded southern part of the Oklahoma coalfield. As several of the available detailed geologic reports on parts of this southern area include structure contour maps, the locations of the lines bounding coal in the three overburden categories were readily and accurately determined for much of the area by comparing these maps with topographic maps. The amount and proportion of Oklahoma coal that falls within each of the overburden-thickness categories are shown in figure $38 \mathrm{C}$.

Preparation of a separate estimate of strippable coal reserves of Oklahoma has not been attempted, because the detailed information that is required to determine whether or not a part of a coal bed can be mined economically by stripping methods is lacking. More than half of the coal produced in the State each year since 1942 has been mined by this method, however.

\section{CLASSIFICATION ACCORDING TO ABUNDANCE OF RELIABLE DATA}

Coal reserve estimates of the Geological Survey are divided into three categories termed "measured," "indicated," and "inferred," according to the abundance of reliable data on which they are based.

Measured reserves are those for which tonnage is computed from: measurement at outcrops and in mine workings and drill holes. The points of observation are so closely spaced and the thickness and extent of the coal so well defined that the computed tonnage may be considered to be within 20 percent or less of the true tonnage. Although the spacing of points of observation necessary to demonstrate continuity of coal varies in different-regions according to the character of the coal beds, structural conditions, and other factors, the points of observation are in general less than half a mile apart.

Indicated reserves are those for which tonnage is computed partly 
from specific measurements and partly from projections of visible data for a reasonable distance on geologic evidence. In general the points of observation are a maximum of about 1 mile apart, but they may be as much as $1 \frac{1}{2}$ miles apart for beds of known continuity.

Inferred reserves are those for which quantitative estimates are based largely on a broad knowledge of the coal bed or region and for which there are few, if any, measurements. The estimates are based on an assumed continuity of the coal bed for which there is good geologic evidence. In general, inferred coal lies more than 2 miles from the outcrop. The outer limit of a block of inferred coal was determined according to the assumptions outlined in a succeeding section entitled, "Methods of recording data and making calculations."

\section{DISTINCTION BETWEEN ORIGINAL, REMAINING, AND RECOVERABLE RESERVES}

The reserve estimates of coal in this report are given in terms of both original and remaining reserves as of January 1, 1953 (see table 1). Original reserves are reserves of coal in the ground before the beginning of mining operations; in their calculation no allowance need be made for production or for mining losses. Remaining reserves are those remaining in the ground available for mining, as of a certain date, and are obtained by subtracting from original reserves the production, losses, and coal rendered unminable up to that date.

The mined-out areas of each coal bed were plotted on the work maps used in preparing this estimate, as were the areas of coal that will probably be left.in barrier pillars around abandoned mines when mining is resumed in the future. By measuring separately the remaining coal and the amount of coal mined out and left in barrier pillars, an estimate of the total amount of coal originally present (original reserves) was prepared. This process also yielded estimates of coal in each bed remaining in the ground for future mining as of January 1, 1953 (remaining reserves). Although the mined-out areas in each coal bed are imperfectly known, just as the exact thickness and extent of each of the coal beds are imperfectly known, the tonnage figures for mined-out areas, including barrier pillars, are probably within 20 percent of the true figures, and the estimates may therefore be considered to be as accurate as the measured-reserve category.

Only a part of the remaining reserves can be recovered, owing to losses incident to future mining. These recoverable reserves cannot be calculated exactly, but they can be approximated by applying to remaining reserves an estimate of future recoverability percentage. For the United States as a whole, roughly 50 percent of the coal in 
the ground is recovered, and 50 percent is left underground in pillars, as layers in the floor and roof, and in flooded, caved, and abandoned areas (Averitt, Berryhill, and Taylor, 1953, p. 12). In the Henryetta mining district the recoverability in underground mining has been 50.5 percent (Dunham and Trumbull, 1955), but it has averaged only 39 percent in Oklahoma as a whole (p. 367). For convenience, the recoverable reserves of Oklahoma may be regarded as roughly 40 percent of remaining reserves, although it is apparent that this performance is exceeded in many individual operations, and that with widespread introduction of improved mining practices; a higher overall average recoverability could be obtained for the State.

\section{METHODS OF RECORDING DATA AND MAKING CALCULATIONS}

The tonnage estimates in this report were calculated and are presented by individual beds, using counties as areal units. Work maps on a scale of 2 inches $=1$ mile $(1: 31,680)$ were prepared from published topographic maps, and the outcrop of each coal bed was traced onto a separate set of these maps. All measured sections, drill-hole measurements, mine information, and other data pertaining to a coal bed were then plotted on the individual work maps. On the basis of. this information, isopach lines were drawn to divide the coal into three thickness ranges; the areas of measured-, indicated-, and inferredreserve categories were established on the basis of the spacing and reliability of the data; areas of coal under each of the three overburden ranges were delineated; and the lines bounding coal of different ranks were added.

The thickness of the coal in each area thus delineated was obtained by taking a weighted average of all thickness figures from mine and outcrop measurements and from drill-hole logs. The thicknesses used were the actual measured thicknesses of the coal bed excluding partings more than three-eighths inch thick, unless the partings exceed half the thickness of the coal bed, in which case the coal was not included in the estimate.

The lateral extent of the coal beds was determined by the extent of the known outcrop and by drill-hole and mine data. Each length of outcrop throughout which the coal was known to be thicker than 14 inches was considered to establish the presence of coal in a semicircular area back from the outcrop having a radius of one-half the length of the outcrop, unless drill-hole or mine data or known variability of the coal bed indicated that this semicircle should be extended or restricted.

Because of the scarcity or lack of information on bed thickness in areas where the coal is classed in the indicated- and inferred-reserve categories, the assumption was made that each coal bed decreases 
regularly in thickness in all directions from areas or points of known thickness and at a rate generally equal to the average amount of thickening or thinning of the bed demonstrated by thickness measurements nearby.

The conservative viewpoint of these assumptions of semicircular extent and decreasing thickness is a large factor in accounting for the difference between the total figure given in this report for the coal resources of the State, and the larger figure that has been accepted heretofore.

The areas outlined on the work maps by the procedures described above were measured with a planimeter to obtain the acreage underlain by coal in the different thickness, reserve, overburden, and rank categories within each township. In areas of steeply dipping coal in the folded southern part of the coalfield, the acreage as measured by the planimeter was increased by a small factor to take into account the presence of more than 1 acre of coal under one surface, or horizontal, acre. The tonnage was then calculated by multiplying together the number of acres, the weighted average thickness of the coal to the nearest whole inch, and the factor 150, which is considered to be the weight of an acre-inch of bituminous coal in the ground. This calculation was performed by electrically operated punched-card equipment, which was also used to sort and total the data according to various reserve categories.

The calculating machines were set to carry all figures to the nearest 10,000 tons, primarily to insure the preservation and incorporation of figures for the smaller areas. The detailed tables contained in this report thus give totals rounded to the nearest 10,000 tons, which unintentionally implies an order of accuracy that is not justified by the means used to obtain the figures.

\section{STATUS OF BASIC INFORMATION AND AREAS EXCLUDED FROM ESTIMATE}

In common with most of the large coalfield areas in the United States, the Oklahoma coalfield has been only partly explored and mapped. (See fig. 37.) The following is a general statement of the status of basic information on the occurrence of Oklahoma coal.

Through the work of the Oklahoma Geological Survey, both published (Oakes, M. C., 1940, 1944, 1952) and unpublished, detailed mapping and thickness measurements are available for much of the extent of the Dawson, Croweburg (Broken Arrow), and Iron Post coal beds in northeastern Oklahoma; but there are extensive areas to the east of the outcrop of the Croweburg bed, in Nowata, Craig, Ottawa, Rogers, Mayes, and Wagoner Counties, where coal that is known to occur in many relatively thin beds has been mined on a 
commercial scale, but where the outcrops of the coal beds have not been mapped, nor adequate thickness measurements been made. For these reasons it was concluded during the preparation of this report that no reasonably accurate estimate of the reserves in these thin beds was possible.

Large areas between the Arkansas and the Canadian Rivers are also as yet inadequately mapped. The Henryetta-Morris mining area in Okmulgee County has been mapped in detail, but the northward extent of the Henryetta and Morris coal beds into northeastern Okmulgee County is not well known. Western Muskogee County and nearly all of McIntosh County are not mapped in sufficient detail.

Detailed and recent surface geologic maps, and their accompanying geologic reports, in which are compiled much information from mining and drilling, cover most of the southern part of the Oklahoma coal field. They have contributed greatly to the accuracy and detail, as well as the amount, of the reserve estimates in this report. The coal deposits of Sequoyah County, however, from which there has been large production by strip-mining methods in recent years (see table 6 ), were not adequately mapped at the time this report was prepared.

Only the status of surface mapping and measurement is discussed above. Information about thickness and extent of beds underground away from the outcrop is limited, in northeastern Oklahoma and in the area between the Arkansas and Canadian Rivers, almost entirely to very shallow holes drilled near the outcrops of coal beds to delineate areas of coal that can be economically strip mined. Information on the occurrence of coal at depths greater than 100 feet is almost entirely lacking there. Two outstanding exceptions, and good examples of the effectiveness of deep exploratory drilling for coal, are the Henryetta coal field, where six diamond-drill holes about 600 feet deep have revealed that coal of minable thickness extends over many square miles; and an area in northern Craig County, where core drilling has disclosed the presence of minable coal at a depth of several hundred feet, though no indication of its presence can be gained from the surface outcrops of the same strata to the east. The drilling in both of the areas mentioned was done many years ago. The assumption is that further deep-test drilling for coal might very possibly bring to light further extensive deposits of minable coal in northeastern Oklahoma as well as in other parts of the coalfield.

A relatively large amount of deep drilling specifically for information on coal beds has been done in the southern part of the Oklahoma coalfield, and the results have materially increased the amount of coal known to be present there; but a vastly greater amount of such exploration is necessary for an adequate knowledge of the coal deposits. 
The areas on anticlines back from the outcrops where the McAlester and Hartshorne coal beds are brought near enough to the surface to be reached by shafts are of particular interest as mining possibilities, if the coal can be shown to be present in beds of adequate thickness.

Although many test wells have been drilled for oil and gas in the coal-bearing region of Oklahoma, the thickness of the coal beds is rarely stated in the drill logs, and where coal is noted, the recorded thickness is unreliable. Records of oil- and gas-drilling operations were not used as a basis for estimating coal reserves in this report.

\section{COMPARISON WITH OTHER ESTIMATES}

\section{CAMPBELI ESTIMATE}

'The only previous estimate of the coal resources of Oklahoma as a whole is that prepared under the direction of M. R. Campbell in the years before 1928, and recently reprinted by Averitt, Berryhill, and Taylor (1953, tables 1 and 2). Campbell estimated the original coal reserves of the State at 54,951 million tons, a figure far higher than the 3,673-million-ton estimate of this report. A detailed comparison of the two estimates is shown in table 4.

TABLE 4.-Comparison of past and present estimates of the original coal reserves of Oklahoma

\begin{tabular}{|c|c|c|c|c|c|c|}
\hline \multirow[b]{2}{*}{ Bed } & \multicolumn{4}{|c|}{ Campbell estimate } & \multicolumn{2}{|c|}{ Present report } \\
\hline & $\begin{array}{c}\text { Assumed } \\
\text { extent } \\
\text { (square } \\
\text { miles) }\end{array}$ & $\begin{array}{c}\text { Assumed } \\
\text { average } \\
\text { thickness } \\
\text { (inches) }\end{array}$ & $\begin{array}{c}\text { Tonnage (in } \\
\text { thousands } \\
\text { of short } \\
\text { tons) }\end{array}$ & $\begin{array}{l}\text { Percent } \\
\text { of total }\end{array}$ & $\begin{array}{c}\text { Tonnage (in } \\
\text { thousands } \\
\text { of short } \\
\text { tons) }\end{array}$ & $\begin{array}{l}\text { Percent } \\
\text { of total }\end{array}$ \\
\hline \multirow[b]{2}{*}{ All beds. ................. } & \multicolumn{6}{|c|}{ Area south of Sequoyah County and Canadian River } \\
\hline & & .....- & $14,817,041$ & 27 & $2,926,980$ & 80 \\
\hline & \multicolumn{6}{|c|}{ Area north of Canadian River, including Sequoyah County } \\
\hline $\begin{array}{l}\text { Dawson } \\
\text { Henryetta and croweburg } \\
\text { Lower beds... }\end{array}$ & \multirow[t]{2}{*}{$\begin{array}{l}1,692 \\
9,324 \\
5,148\end{array}$} & \multirow[t]{2}{*}{$\begin{array}{l}27 \\
30 \\
18\end{array}$} & $\begin{array}{r}4,385,664 \\
26,853,120 \\
8,895,744\end{array}$ & $\begin{array}{r}8 \\
49 \\
16\end{array}$ & $\begin{array}{r}81,080 \\
433,920 \\
230,840\end{array}$ & $\begin{array}{r}2 \\
12 \\
6\end{array}$ \\
\hline Total.... & & & $40,134,528$ & 73 & 1745,840 & 20 \\
\hline State total..... & 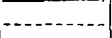 & & $54,951,569$ & 100 & $3,672,820$ & 100 \\
\hline
\end{tabular}

1 Estimate includes only a part of northeastern Oklahoma. See text.

The Campbell estimate was made with the same cutoff points as the present estimate, namely a minimum bed thickness of 14 inches and a maximum overburden thickness of 3,000 feet, and employed the same figure of 1,800 tons for the estimated weight of an acre-foot of bituminous corl in the ground, but none of the detailed geologic reports (see list, fig. 37) and only a part of the results of the exploratory drilling 
upon which the estimates in the present report are primarily based were in existence when the early estimate was prepared. The use of this wealth of information in the preparation of the present report has made possible an estimate based entirely and conservatively on known measurements and has resulted in a minimum rock-bottom estimate that includes no assumptions or tonnage figures for vast areas of coalbearing land in the State for which information is still inadequate or entirely lacking. When the earlier estimate was made it was necessary to make estimates and statistical allowance for the continuity in extent and thickness of the coal beds in order to produce a workable total figure.

In the preparation of the Campbell estimate, for instance, the Henryetta and Croweburg (Broken Arrow) beds were correlated (as they also are in the present report) and considered as one continuous bed, the outcrop of which, in the words of the original notes,

has been traced from the Kansas-Oklahoma State line southwest to beyond Henryetta. This bed has been considered as extending south to the Canadian River. The coal dips west at 50 feet per mile. It would therefore reach a depth of 3,000 feet at 60 miles from the outcrop.

On the map which accompanies the notes from which the above is quoted, the Canadian River has been used as the southern boundary of the area underlain by coal, and the line labeled "3,000-foot limit of Henryetta coal" includes all of Seminole, Creek, and Washington Counties, about nine-tenths of Pottawatomie County, more than half of Lincoln and Osage Counties, parts of Pawnee and Payne Counties, and very nearly all of Nowata, Tulsa, and Okfuskee Counties, in the 9,324-square-mile area which was considered to be underlain by coal in this bed. Over this entire area the bed thickness was considered to average 2 feet 6 inches. The area which in the present report is considered to have been originally underlain by all categories of reserves in the Henryetta bed is slightly less than 120 square miles, and in the Croweburg (Broken Arrow) bed is about 70 square miles. (See pl. 17.)

In the Campbell estimate the Dawson coal bed was considered to average 2 feet 3 inches in thickness over a 1,692-square-mile area bounded by the outcrop extending from a point in T. 15 N., R. 11 E., near Beggs, to a point in T. 25 N., R. 15 E., and by a semicircular arc . which included within the coal area more than one-third of both Creek and Osage Counties, a part of Pawnee County, and about half of Washington County. In the present report, the area underlain by all categories of original reserves in the Dawson coal bed is less than 50 square miles. (See pl. 17.)

Reserves of coal in northeastern Oklahoma in beds below the Broken Arrow coal bed were assumed in the Campbell estimate to be equivalent 
in amount to those in one bed having an overall average thickness of 18 inches and an extent of 5,148 square miles; but in the preparation of the present report the information available about these beds was considered too fragmentary for estimating anything but an extremely small amount of coal in uncorrelated beds in Craig and Rogers Counties.

Tonnage calculations based on the three assumptions just mentioned account for 73 percent of the total Campbell reserve estimate for the State.

The Campbell estimate of the coal reserves of the southern part of the Oklahoma coalfield was based on an estimate of the coal reserves of the segregated Indian lands (for a discussion of segregated lands, see Shannon and others, 1926, p. 102-105) prepared by G. H. Ashley before 1910. This estimate, which is printed on pages 91 to 115 of U. S. Senate Document 390, was recalculated from the basis of 1,000 tons per acre-foot on which it was made, to the basis of 1,800 tons per acre-foot which is common to both the Campbell estimate and the present report. To this figure of 3,573 million tons was then added an estimate of 11,244 million tons for coal thought to be preseńt under unsegregated land.

In preparing those estimates, a figure for average bed thickness was applied uniformly to areas which were often of township size or even hundreds of square miles in extent. For example, the area of about 720 square miles comprising Tps. 7-10 N., Rs. 15-19 E., was considered to contain coal equal in amount to that in a bed 2 feet thick over the entire area, which added $1,658,880,000$ tons to the Campbell total. In the present report, coal reserves in all beds in this area total only 107,410,000 tons, or 6.5 percent of the above figure.

The availability of structure contour maps has also made it possible, in preparing the present report, to locate the 3,000-foot overburden line on each coal bed with some degree of accuracy. In many areas this has eliminated from the present estimate large quantities of coal included in the earlier estimate.

\section{CORPS OF ENGINEERS ESTIMATE}

Another estimate of the coal resources of Oklahoma, recently prepared under the auspices of the Corps of Engineers, Department of the Army, shows 2,467,094,000 tons of coal in place, of which 1,251,588,000 tons was considered to be recoverable (Corps of Engineers, 1951). The Corps of Engineers report was prepared especially for determining areas suitable for the location of synthetic liquid fuel plants. It was based on different assumptions and thus is not closely comparable with either the Campbell estimate or the estimates in this report.

The object of the Corps of Engineers survey was to locate large 
blocks of coal in which large-scale mining could be started immediately to supply synthetic fuel plants that might be constructed. The Corps' estimate of coal reserves includes only coal thicker than 24 inches for underground mining and thicker than 12 inches for strip mining; and less than 1,500 feet below drainage level for underground mining and under less than 200 feet of overburden for strip mining, with additional restrictions as to the thickness ratio of coal bed and overburden. The Geological Survey coal reserve estimates are computed for bedthickness ranges of 14 to 28,28 to 42 , and more than 42 inches; and for overburden thickness ranges of less than $1,000,1,000$ to 2,000 , and 2,000 to 3,000 feet. The Corps of Engineers total figure is thus roughly comparable to this report's estimate of reserves in beds thicker than 28 inches and within 1,000 feet of the surface.

\section{ARRANSAS ESTIMATE}

The 14,550-square-mile Oklahoma coalfield is estimated to have contained original coal reserves of 3,673 million short tons, whereas a similar investigation (as yet unpublished) of the 1,700-square mile Arkansas coalfield resulted in an original reserve estimate of 2,265 million short tons. The contrast between a ratio of areas of 8.5 to 1 and a ratio of original reserves of 1.6 to 1 is in part due to the effect on the estimate of such factors as the geological mode of occurrence of the coal beds and the relative amount of available information about the coal beds.

The coal beds in Arkansas have gentle dips, are less than 3,200 feet deep, and can be correlated by surface mapping or stratigraphic similarity on opposite sides of synclines. These three factors plus abundant data on the thickness of the coal act to increase the total estimate of reserves there.

\section{THE OKLAHOMA COALFIELD}

\section{GENERAL INFORMATION}

The main coal-bearing area of Oklahoma is located in the northeastern and east-central parts of the State, and has a maximum northsouth extent of about 185 miles and a maximum east-west extent of about 110 miles. The total area underlain by coal-bearing rocks is about 14,550 square miles, or roughly 21 percent of the total area of the State; coal is present at the surface in more than 17 counties. The general location of the coal-bearing areas is shown on the index map, figure 37.

The coal-bearing rocks of eastern Oklahoma are continuous with those of Arkansas on the east and of Kansas on the north, and the coalfields of these three States, together with those of Missouri, Iowa, and Nebraska, form the Western region of the Interior province, one 
of the major areas of coal occurrence in the United States. Boundaries of the Oklahoma coalfield other than those formed by the Arkansas and Kansas State lines are the older rocks elevated by the Ozark uplift on the northeast, the faults and folds of the Ouachita Mountains on the south, and the younger, non-coal-bearing rocks on the west.

The coal-bearing area of eastern Oklahoma, commonly referred to as the Oklahoma coalfield, contains very nearly all the coal in the State, but a few relatively small deposits of coal are known in other parts of the State. One or more coal beds are known to occur in rocks of Pennsylvanian age in Carter County, just south of the Arbuckle Mountains in the south-central part of the State; and a thin impure bed of lignite is present in rocks of Cretaceous age in Cimarron County, at the extreme western end of the panhandle of the State, near the New Mexico border. These occurrences of coal outside the main Oklahoma coalfield are more fully discussed in a succeeding section of this report. Because they are extremely small in size and are inadequately known, no reserve estimates for these areas are given in this report.

The Oklahoma coalfield can be divided naturally into northern and southern parts which are of about equal extent, but which differ in structure and topography. The dividing line can be considered to be the Canadian River and the part of the Arkansas River below their confluence.

The northern part of the Oklahoma coalfield lies in the Osage Plains section of the Central Lowland physiographic province. The land surface there.is for the most part flat lying or gently rolling plains of low relief formed on the thick shale beds that predominate in the geologic section. Those low plains are interrupted by widely spaced low rounded eastward-facing cuestas which trend generally northeast-southwest, parallel to the regional strike, and are formed by resistant but relatively thin limestone and sandstone beds in the section. Elevations range from slightly less than 500 feet above sea level in the lower parts of the major river valleys to about 1,000 feet on the highest hills. Two hundred to 250 feet of relief in a short distance is common on the eastward side of the cuestas and on the outlier hills caused by the more resistant of the sandstone and limestone beds, and also where hills and cuestas are cut through by the major streams. Over most of the area the local relief is less than this. Near to and south of the Arkansas River there is a rather pronounced southward increase in the relative amount of sandstone in the coalbearing part of the geologic section, with the result that near the boundary between the two parts of the Oklahoma coalfield the land surface becomes in places hillier than it is farther north. Valleys of 
the major streams are generally wide, sand choked, and slightly entrenched.

The southern part of the Oklahoma coalfield for the most part coincides closely with the Oklahoma portion of the Arkansas Valley section of the Ouachita physiographic province. The structure of the southern part of the Oklahoma coalfield consists principally of a series of eastward- and northeastward-trending folds. Erosion of the folded rocks, which are for the most part a repetitive series of sandstone and shale beds, has produced a land surface of relatively strong relief, characterized by long curving subparallel hogbacks or sharp hills that coincide generally with the outcrop of the resistant sandstone beds. Between these hills are wide and extensive valleys of low relief, which are formed on the thick shale beds. Where the dips are low, the sandstone outcrops form extensive broad areas of relatively strong relief, but where the dips are high the sandstone outcrops form narrow closely spaced hogbacks. The highest land in the coalfield occurs along the axes of some of the synclines where the flat-lying sandstone beds are most resistant to erosion; in contrast, the anticlines often have very little topographic expression. Poteau Mountain, whose crest elevation of about 2,530 feet makes it the highest point in the Oklahoma coalfield, and Cavanal Mountain, with an elevation of more than 2,300 feet, are excellent examples of such synclinal erosional features. The lowest point in the Oklahoma coalfield is in the valley of the Arkansas River where it leaves the State near Fort Smith, Ark.; the' elevation there is less than 400 feet.

The Arkansas River and its tributaries drain all of the Oklahoma coalfield except the extreme southwestern part, in Coal, Atoka, and southwestern Pittsburg Counties. This small area is drained by Muddy Boggy Creek and its tributaries, which flow southward and southwestward to join the Red River at the Texas State line.

Nearly all the streams in the Oklahoma coalfield flow in broad meanders in wide valleys filled with loose sand and silt, and most of the smaller streams flow only intermittently.

Information about the location, adequacy, and quality of water supplies for industrial and other uses in Oklahoma is contained in a report entitled "Oklahoma water," prepared in 1945 for the Oklahoma Planning and Resources Board by the Water Resources Division of the U. S. Geological Survey.

Temperatures in the Oklahoma : coalfield range from an average maximum of $47^{\circ} \mathrm{F}$ and an average minimum of $28^{\circ} \mathrm{F}$ in January to an average maximum of $92^{\circ} \mathrm{F}$ and an average minimum of $70^{\circ} \mathrm{F}$ in August. The winters are mild; the summers are hot, with temperatures of more than $100^{\circ} \mathrm{F}$ occurring on many successive days in July. 
and August. The average annual relative humidity is 66 percent. The average annual precipitation in the Oklahoma coalfield ranges from 38 inches along the west side of the field to 42 inches in the southeastern part of the field.

The population density of the Oklahoma coalfield is about 30 persons per square mile, exclusive of metropolitan areas. Tulsa, 1950 population 182,740, and Muskogee, 1950 population 37,289, are located within the coalfield and are respectively the second and third largest cities in the State, but their growth is not to be attributed in great degree to the coal-mining industry. Smaller cities, such as McAlester (population 17,878), Henryetta (population 7,987), and Poteau (population 4,776), have long been important in the industry and owe much of their growth to it.

Many other smaller towns in the area have been important mining centers in the past, but the decline in underground mining activity in the last 25 years (fig. 43) has reduced their chief means of employment. The growth of strip mining in more recent years has tended to reverse this trend somewhat in some of these communities and has also increased employment in many small towns in the northern part of the Oklahoma coalfield, where there was little mining activity before the advent of large-scale strip mining.

Both the northern and southern parts of the Oklahoma coalfield are adequately served by a network of several railroad lines. Largescale mining in the southern part of the Oklahoma coalfield started immediately upon completion of the Missouri-Kansas-Texas Railroad through McAlester in 1872. Similarly, construction of railroad lines through Latimer and Le Flore Counties and other parts of the State in succeeding years was followed closely by mining development.

Very good highway access to all parts of the Oklahoma coalfield is provided by a network of State and Federal highways and by many unpaved county and State roads.

\section{STRATIGRAPHY OF THE SOUTHERN PART OF THE OKLAHOMA} COALFIELD

The coal-bearing rocks of eastern Oklahoma are of Pennsylvanian (Des Moines and Missouri) age, and correspond roughly in age to Upper Pottsville, Allegheny, and Conemaugh beds of the eastern United States. The names applied to the coal-bearing rocks of Oklahoma are shown on plate 16.

The coal-bearing rocks of the southern and northern parts of the Oklahoma coalfield have been for the most part subdivided differently, and different names have to some extent been given to the formations, oven though rocks of the same age occur in both areas. 
The southern part of the Oklahoma coalfield is continuous with the Arkansas coalfields on the east, and the two areas are known jointly as the Arkansas-Oklahoma coal basin. The rocks that crop out within this deep structural and depositional coal basin, the western part of which is often referred to as the McAlester basin, are of Atoka and Des Moines age, and constitute a thick sequence of alternating sandstones and shales and numerous coal beds. The formations into which these rocks have been divided are, in ascending order, the Atoka formation, the Hartshorne sandstone, the McAlester formation, the Savanna formation, and the Boggy formation. These formations, excluding the Atoka, constitute in this area the newly established (Oakes, 1953) Krebs group; and the Cabaniss group here consists of the still higher Thurman sandstone, Stuart shale, and Senora formation, which crop out northwest of the McAlester basin proper and extend for some distance north of the Canadian River. Except for the Atoka, Thurman, and Stuart formations, all of these units contain coal beds that have been extensively mined.

\section{ATOKA FORMATION}

The Atoka formation underlies the Hartshorne sandstone throughout its extent in Oklahoma. It is exposed south of the long narrow continuous outcrop of the Hartshorne sandstone that extends along the entire southern boundary of the Oklahoma coalfield, from the Lehigh-A toka area in Coal and Atoka Counties eastward to Arkansas.

The Atoka is also exposed inside the long U-shaped outcrops of the Hartshorne sandstone in the Backbone anticline in Le Flore County and the Milton anticline in Haskell and Le Flore Counties; along parts of the Lone Star anticline in northern Haskell County; and east of the outcrop of the Hartshorne sandstone in eastern Muskogee County, between the Canadian and the Arkansas Rivers. (The location of the major faults and the traces of the axes of the major anticlines and synclines in the southern part of the Oklahoma coalfield are shown in fig. 41.) The Atoka formation or its correlatives extend northward into northeastern Oklahoma at least as far as T. 24 N., and until recently they were considered the basal part of the Cherokee formation there.

The Atoka formation is about 9,000 feet thick in central Le Flore County; in the southeastern corner of the Oklahoma coalfield, and it thins rapidly northward and westward, being about 600 feet thick in the Muskogee area. It consists almost entirely of alternating beds of sandstone and shale: Coal-forming conditions do not seem to have developed until near the end of the time during which the Atoka formation was deposited, for only a few thin beds of coal have been 
found in the Atoka, and these are concentrated near the top of the formation.

The oldest coal bed known in Oklahoma is the topmost bed of the Bloyd shale, just below the base of the Atoka formation. Maximum observed thickness of this bed is 0.8 feet in the NE $1 / 4$ sec. 20, T. $15 \mathrm{~N}$, R. 20 E., Muskogee County, a locality described by C. A. Moore (1947, p. 40-42, pl. 7A).

\section{HARTSHORNE SANDSTONE}

The Hartshorne sandstone is a unit 10 to 300 feet thick, composed in some places of nearly pure massive to very irregularly bedded quartzose sandstone, and in other places of impure shaly sandstone and shale. It is persistent throughout the southern part of the Oklahoma coalfield, and the similar persistence over this large area of the Lower Hartshorne coal bed that occurs in it marks the first prolonged period of coal-forming conditions in the area. The Hartshorne sandstone has been mapped northward almost to the latitude of Muskogee, where it has thinned to only 10 feet, and its correlatives may or may not extend on northward from there.

Detailed mapping has revealed that the Lower and Upper :Hartshorne coal beds, which are separated by 20 to 70 feet of sandstone and shale throughout most of the southern part of the Oklahoma coalfield, converge northward in the vicinity of Bokoshe, Le Flore County, and McCurtain, Haskell County, where the two coal beds join or are separated by only a few inches to a few feet of impurities. Where the two coal beds have joined or are very close together, they are jointly referred to as the Hartshorne coal. As the boundary between the Hartshorne sandstone and the overlying McAlester formation is placed, in Oklahoma usage, within the strata that disappear with the coalescence of the two coal beds, the top of the Hartshorne sandstone in Haskell County and northern Le Flore County is placed at the top of the Upper Hartstone coal bed. As a result, the Upper Hartshorne coal is included with the Lower Hartshorne coal in the Hartshorne sandstone in this area but remains in the overlying McAlester formation elsewhere in the State. (See fig. 40.)

\section{MCALESTER FORMATION}

The McAlester formation is exposed in a continuous belt on the north side of the outcrop of the underlying Hartshorne sandstone along the entire southern margin of the Oklahoma coalfield, from Atoka and Lehigh on the west to the Arkansas State line on the east, and it is exposed at the surface in extensive areas in the Brazil anticline in northeastern Latimer County and the Bokoshe syncline and a large area east of Poteau in northern Le Flore County. It is also exposed 
S.

$$
\begin{gathered}
\text { Hughes, } \\
\text { Latimer County } \\
\downarrow
\end{gathered}
$$

McCurtain, Haskell County

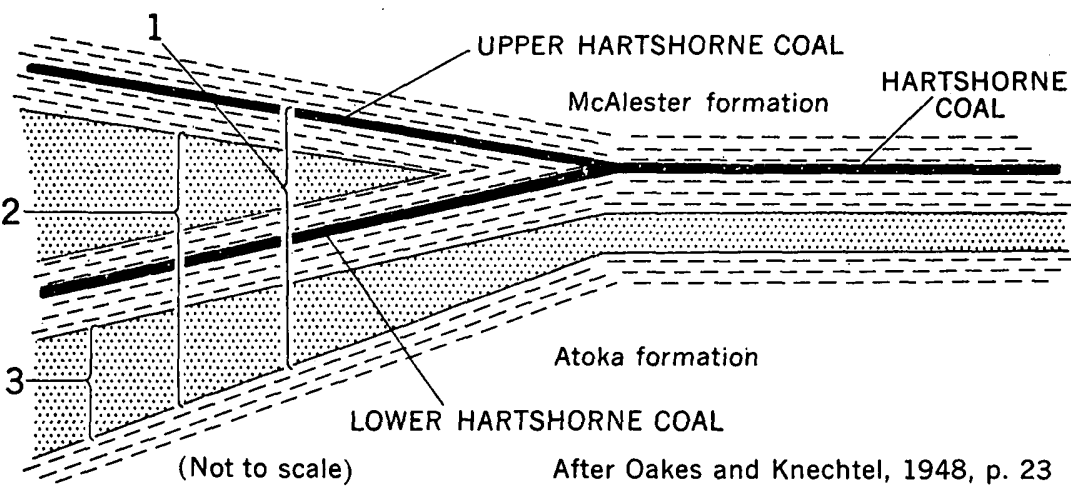

Fiaure 40.-The Hartshorne sandstone (1) as defined in Haskell County and northern Le Flore County, Okla., (2) of general Oklahoma usage, and (3) of Arkansas usage.

over much of Haskell County, and in large but not accurately known areas in southern Sequoyah County, north of the Arkansas River. It has been mapped in detail in Muskogee County from the Canadian River northward to the Arkansas River near Muskogee, and the recent application of the formation names of the Krebs group to the rocks of northeastern Oklahoma has resulted in the extension of the McAlester formation to the Kansas line.

The McAlester formation is from 1,750 feet to 2,500 feet thick along the southern margin of the Oklahoma coalfield, and, like other coalbearing formations in the area, it thins northward and westward, being 500 to 700 feet thick. in northern Haskell County and southern Muskogee County, and about 200 feet thick at the latitude of Muskogee. The formation continues to thin northward from Muskogee, and in northeastern Oklahoma it is represented in the lower part of the Cherokee formation as defined in the older geologic literature. The lowest named sandstone unit in the McAlester formation is the Warner sandstone member, and this name has recently been applied to what was previously called the Little Cabin sandstone member in northeastern Oklahoma.

Shale makes up most of the McAlester formation, but several named sandstone beds and a number of coal beds occur within the formation. The shale between the base of the McAlester formation and the Warner sandstone member of the McAlester is known as the McCurtain shale member, and throughout much of the southern part of the Oklahoma. 
coalfield it contains the thick, extensive, and valuable Upper Hartshorne coal bed. Next above the Warner sandstone member, and separated from it and from each other by shale, are the Lequire and Cameron sandstone members. The shale above the Cameron sandstone contains the important McAlester (Lehigh) and Stigler coal beds. The two next succeeding sandstone beds are the Tamaha and Keota sandstone members. Until recently they were in the Savanna formation, but they are now in the McAlester formation as defined by the Oklahoma and U. S. Geological Surveys.

\section{SAVANNA FORMATION}

The Savanna formation crops out over extensive areas in Coal, Atoka, Pittsburg, and northern Latimer Counties, the southern part of Haskell County, and northern Le Flore County. It attains a maximum thickness of about 1,750 feet in Le Flore and Atoka Counties, but it thins rapidly underground to the west and northwest. Northward where it has been mapped as a narrow outcrop through Muskogee County it is only 25 to 80 feet thick.

The base of the Savanna formation is now considered by the Oklahoma and U. S. Geological Surveys to be at the base of the Spaniard limestone member of the Savanna (pl. 16). The base of the Bluejacket sandstone member of the overlying Boggy formation marks the top of the Savanna formation. The Savanna, in common with the McAlester, Boggy, and Senora formations, has recently been mapped northward to Kansas (Miser, 1954).

For the most part the Savanna formation is composed of alternating beds of shale and sandstone. A subordinate amount of limestone is present, especially in the more northerly outcrops, and numerous thin coal beds, of which the Cavanal is the most important, occur in the shale parts of the formation.

\section{BOGGY FORMATION}

The outcrop area of the Boggy formation, including the Blnejacket sandstone member at the base, is more extensive than that of any other in the southern part of the Oklahoma coalfield. It is exposed in a wide arcuate belt from southeastern Pontotoc County and central and northern Coal County through Pittsburg, western Haskell, and McIntosh Counties to northwestern Muskogee County. From here it has been mapped northward to the Kansas line. Large outliers of the Boggy formation remain in the Sansbois syncline in Haskell and northern Latimer Counties, where more than 2,000 feet of the formation is present, and in the Cavanal syncline in Le Flore County, where more than 3,000 feet of rocks in the Boggy formation make up much of the mass of Cavanal Mountain. 
A complete continuous section of the Boggy in Pittsburg County is about 2,850 feet thick, and to the west in Coal County it is 1,250 to 1,500 feet thick. The formation is also known to become thinner northward from Pittsburg County, but its thickness there has not been measured.

Much of the formation is composed of a thick sequence of shale beds that are separated by varying numbers of sandstone beds of irregular thickness and lithologic character. The Lower Witteville and several other thinner coal beds occur near the bottom of the formation at some places, and the higher Secor (Upper Witteville) coal bed is present over large areas. The formation also includes a limestone unit, the Inola limestone member, which is traceable into northeastern Oklahoma.

\section{THURMAN, STUART, AND SENORA FORMATIONS}

The formations next above the Boggy are the Thurman sandstone, the Stuart shale, and the Senora formation, which in this area constitute the Cabaniss group. Neither the Thurman nor the Stuart formation has been reported to contain coal, but the coal beds in the Senora formation have been mined extensively near Henryetta and Morris in Okmulgee County.

The Thurman sandstone crops out in a strip a few miles wide extending through northern Coal, western and northwestern Pittsburg, and western McIntosh Counties. In northwest Pittsburg County, the only place in which recent detailed investigations of this formation and the overlying Stuart shale have been conducted and published, the Thurman is from 290 to 350 feet thick and consists of alternating beds of sandstone and shale, with a basal bed of conglomerate or coarse sandstone in many places.

The Stuart shale, which crops out parallel to the Thurman on its northwest side, is 315 feet thick in northern Pittsburg County, and consists mainly of dark shales and a subordinate amount of sandstone in the middle portion. The Thurman sandstone is currently considered not to extend north of the Canadian River; the Stuart shale does not extend northward beyond T. 13 N., Rs. 15 and 16 E.

The Senora formation crops out from northeastern Pontotoc County northeastward to the Kansas State line. North of T. 13 N. it is the only formation in the Cabaniss group. South of the Arkansas River the Senora formation, like most of those in the southern part of the Oklahoma coalfield, consists of alternate beds of sandstone and shale, with a very few thin beds of impure limestone in places. In southern Okmulgee County the number and thickness of the sandstone beds decrease markedly in a northward direction (Dunham and Trumbull, 1955, pl. 22). In the Coalgate quadrangle, Hughes and Pontotoc Counties, the Senora thins southwestward from nearly 
500 feet to less than 150 feet; and in southern Okmulgee County, measurements indicate that the upper part of the formation thins northward from more than 700 feet to about 400 feet.

Minable coal beds have not been found in the Senora formation south of Okmulgee County, nor have they been found in higher strata in that area. The Henryetta coal bed has been extensively mined in the southern and central parts of Okmulgee County, and the lower Morris and Eram coals are present in the Senora formation in the east-central part of that county.

\section{STRATIGRAPHY OF THE NORTHERN PART OF THE OKLAHOMA COALFIELD}

From the coalfields of Kansas on the north to their gradual transition into the much thicker section in the coal basin south of the Canadian and Arkansas Rivers, the coal-bearing rocks of northeastern Oklahoma crop out in a belt roughly 30 miles wide, strike between north and N. $30^{\circ}, \mathrm{E}$., and have a low westward dip of $1^{\circ}$ to $3^{\circ}$ that is little interrupted by structural features.

The part of these coal-bearing rocks below the base of the Fort Scott limestone corresponds in age to all the formations that were described for the southern part of the coalfield. (See pl. 16, which shows the relative stratigraphic positions of the coal beds and coalbearing rocks of the Oklahoma coalfield.) Until recently this uniform sequence of thick shale beds and thin sandstone, limestone, and coal beds was known in Oklahoma simply as the Cherokee formation, or Cherokee shale; but recent field work has increased our knowledge of correlations between the southern and northern parts of the Oklahoma coalfield, and on the new edition of the State geologic map (Miser, 1954) the terms Krebs group and Cabaniss group are applied throughout the coalfield. Formational names from the southern part of the coalfield have also been extended through northeastern Oklahoma, with the exception of the Atoka, Hartshorne, Thurman, and Stuart formations, which do not extend as far as Kansas. In the following paragraphs, the rocks of the Krebs and Cabaniss groups and the underlying northerly tongue of the Atoka formation are discussed first.

The rocks above the Fort Scott limestone have been divided into many formations, and four named coal beds are present, one of them in rocks of Des Moines age, and three of them in higher rocks of Missouri age, an age not known to be represented by coal beds anywhere else in the State. Of these four coal beds only one, the Dawson, is thick enough or well-enough known so that estimates of reserves could be prepared for it. 
STRATA BELOW THE FORT SCOTT LIMESTONE

At the base of the coal-bearing section of northeastern Oklahoma, a thin northerly extension of the Atoka formation is present between the bottom of the Krebs group and the top of the Morrow group. This wedge of the Atoka formation is about 600 feet thick in the Muskogee area, but probably neither it nor the underlying rocks of Morrow age extend as far north as Kansas. The Krebs group therefore lies unconformably on rocks of Mississippian age at the Kansas State line.

The Krebs and Cabaniss groups in northeastern Oklahoma are about 500 feet thick near the Kansas State line and slightly more than 1,000 feet thick at the latitude of Tulsa. Thick shale beds predominate in the section, but several relatively thin units of sandstone and limestone have been named and mapped across all or much of the area. Several of these units have been correlated with known units in Kansas and in the area south of the Arkansas River. The better known of these named units, none of which is considered as of formational rank, are, from oldest to youngest, the Warner sandstone member of the McAlester formation (until recently known as the Little Cabin sandstone); the Spaniard limestone member of the Savanna formation; the Bluejacket sandstone member of the Boggy formation, which has been traced from Kansas through northeastern Oklahoma into the McAlester basin; the Chelsea sandstone member of the Senora formation, which has been mapped by Oakes $(1952$, p. 102) southward across the Arkansas River; and the Verdigris limestone member of the Senora formation, which is correlated with the Ardmore limestone member of the Cherokee shale of Kansas.

Numerous thin and to some extent discontinuous coal beds are present in this sequence. The most economically important of these is the Croweburg coal bed; but several other beds have been stripped at a number of localities throughout the area.

\section{HIGHER ROCKS OF DES MOINES AGE}

Rocks of Des Moines age above the top of the Cabaniss group constitute the Marmaton group. They are divided north of the Arkansas River into the Fort Scott limestone at the base; the Labette shale; the Oologah limestone, which is made up, in ascending order, of the Pawnee limestone, Bandera shale, and Altamont limestone members; the Nowata shale; the Lenapah limestone; and at the top, the Holdenville shale. Correlative strata south of the Arkansas River are not known to contain coal except in lenses and streaks; they are divided in ascending order into the Calvin sandstone, the Wetumka shale, the Wewoka formation, and the Holdenville shale. Shale and limestone predominate north of the Arkansas River; shale and sandstone predominate south of the Arkansas River. Rocks of the Marmaton group are about 370 


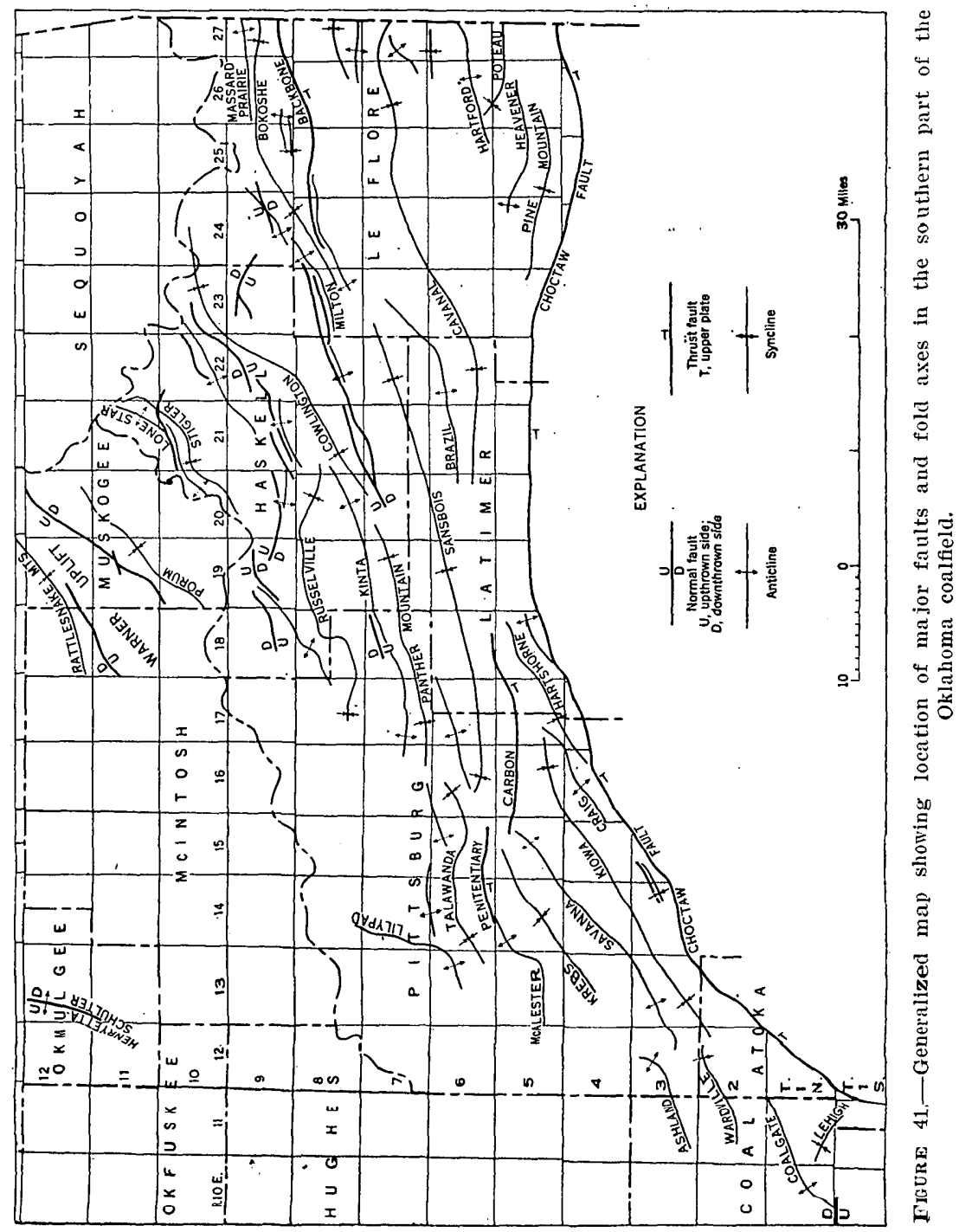


feet thick at the Kansas State line and about 560 feet thick at the latitude of Tulsa. They crop out in a continuous belt, 10 to 20 miles wide, on the west side of the outcrops of the Cabaniss group. The only coal bed known to occur in these rocks in Oklahoma is a thin southward extension of the Lexington coal of Kansas (Cade, 1953, p. 138).

\section{ROCKS OF MISSOURI AGE}

The other coal beds in northeastern Oklahoma occur in rocks of Missouri age, which lie unconformably on the Holdenville shale of Des Moines age. These rocks have been divided into many formations, beginning at the base with the Seminole formation, which contains the important Dawson coal in its lower part. The Seminole formation is composed largely of shale, sandy shale, and sandstone, and is more than 200 feet thick slightly north of Tulsa, but only 10 to 20 feet thick near Kansas. It crops out in a narrow belt south of Tulsa and northward through Tulsa, Washington, Rogers, and Nowata Counties (Oakes, 1940, p. 23-26).

The Seminole formation is overlain by the Checkerboard limestone, and this in turn by the relatively thick Coffeyville formation, which in its upper part includes the thin Cedar Bluff coal, and in its upper few feet includes one or more discontinuous coal stringers. Next above the Coffeyville are in ascending order the non-coal-bearing Hogshooter limestone, Nellie Bly formation, and Dewey formation. These are succeeded by the Chanute formation, near the middle of which is a coal bed correlated with the Thayer coal of Kansas.

The only coal known to occur in stratigraphically higher rocks of Pennsylvanian age in the Oklahoma coalfield, or in rocks of Missouri age south of the Arkansas River, is in thin lenses and streaks.

\section{STRUCTURE OF THE SOUTHERN PART OF THE OKLAHOMA COALFIELD}

Strong compression from a generally southerly direction was exerted upon the southern part of the Oklahoma coalfield at some time after the deposition of the coal-bearing sediments, with the result that throughout that area the beds have been folded into many long, narrow anticlines and synclines whose axes tend generally between east and northeast. The location of the axes of the more prominent of these folds and of traces of the larger faults is shown in figure 41.

The amplitude of the major folding decreases northward. Thus the strata in northern Pittsburg and southern Muskogee Counties lie in a series of gentle folds, whereas the coal beds and other rocks of the southern border of the coalfield have in many places a much higher 
dip, and are vertical or overturned in some localities in Coal, Atoka, and Pittsburg Counties near the Choctaw thrust fault.

The Choctaw fault, a northward-thrust fault at the south edge of the McAlester basin, extends from Atoka County near the southwestern corner of the coalfield northeastward and eastward into the State of Arkansas. Its trace at the surface is commonly considered to mark the southern limit of the Oklahoma coalfield, although a narrow band of the Atoka formation, which here is not known to contain coal beds, is present between the trace of the fault and the outcrop of the Hartshorne sandstone. Thrusting from the south has also been observed in conjunction with the Backbone anticline in northern Le Flore County and in the Penitentiary and Carbon faults north and east of McAlester in Pittsburg County.

After the anticlines and synclines of the southern part of the Oklahoma coalfield were formed, the rocks were greatly eroded, with the result that a large part of the remaining coal beds is preserved only in the synclines. Erosion on anticlines has progressed so far that on three, the Savanna anticline in Tps. 3 and 4 N., Rs. 13 and 14 E., Pittsburg County; the Backbone anticline in northern Le Flore County; and the Milton anticline in eastern Haskell and northern Le Flore Counties, the entire section of coal-bearing rocks has been removed.

The rocks in the synclines are in general more resistant to erosion than those in the anticlines when both are at approximately the same altitude. Thus the higher and more conspicuous mountains, notably Poteau, Cavanal, and Sans Bois in the southeastern part of the coalfield, owe their prominence to the synclinal structure of the rocks that form them.

Many small normal faults are also present throughout much of the southern part of the coalfield, and they are especially numerous in Haskell County. Although these faults are locally of great importance in determining the position of coal bed outcrops, they are too limited in extent to show in figure 41.

Several large subparallel northeastward-trending faults have caused the Atoka formation and the lower part of the Krebs group to be exposed in an irregular pattern of fault blocks on the southwest flank of a lobe of the Ozark uplift, at the eastern edge of the coalfield in western and southern Cherokee County and northwestern Sequoyah County. In the southern half of Sequoyah County, where coal beds of the Krebs group have been extensively strip mined in recent years, the rocks are known to be faulted and folded, but detailed geologic maps of that area have not yet been published. 
The overall structural configuration of the northern part of the Oklahoma coalfield is far simpler than that of the southern part. The coal-bearing rocks throughout this large area have a remarkably uniform gentle westward dip; which is interrupted in only a relatively few localities by faults and gentle folds. The strike of the beds ranges from north to $\mathrm{N} .30^{\circ} \mathrm{E}$., and the dip to the west rarely exceeds 300 feet per mile, or about $3^{\circ}$. It is this very low dip which has made widespread strip mining feasible throughout much of northeastern Oklahoma.

The Henryetta mining district in. southern Okmulgee County is in an area of gentle westward homoclinal dips. The HenryettaSchulter faulted anticline is about 4 miles long and occurs in an area that was extensively mined by underground methods in the past: This structural feature disturbed only an area of a few square miles, and mining is being carried out in a large relatively undisturbed area to the west.

\section{COAL BEDS IN THE SOUTHERN PART OF THE OKLAHOMA COALFIELD}

The thickest, most widespread, and most mined coal beds in Oklahoma are in the southern part of the field. Production figures for individual beds are not available; but the Lower Hartshorne bed (including the Upper Hartshorne where the two are mined as one in eastern Haskell County and parts of northern Le Flore County) and the McAlester bed have alone accounted for perhaps half of the total State production. These and several other named coal beds in the southern part of the coalfield are shown in the stratigraphic diagrams, plate 16 and figure 42, which also indicate their relations with the coal beds of northeastern Oklahoma and the Arkansas coalfield, respectively. Further information concerning the names, occurrence, equivalence, and workable areas of coal beds in Oklahoma, including a complete list of all local names, will be found in a publication of the Oklahoma Geological Survey (The Hopper, 1954).

The named coal beds and the more important unnamed or uncorrelated coal beds in the southern part of the Oklahoma coalfield are discussed briefly below. Averages of the available reliable analyses of the beds in each county are shown in table 5 .

\section{LOWER HARTSHORNE COAL BED}

The Lower Hartshorne coal bed, the oldest important coal bed in Oklahoma and one of the most valuable, lies in the upper part of the $425537-57-6$ 


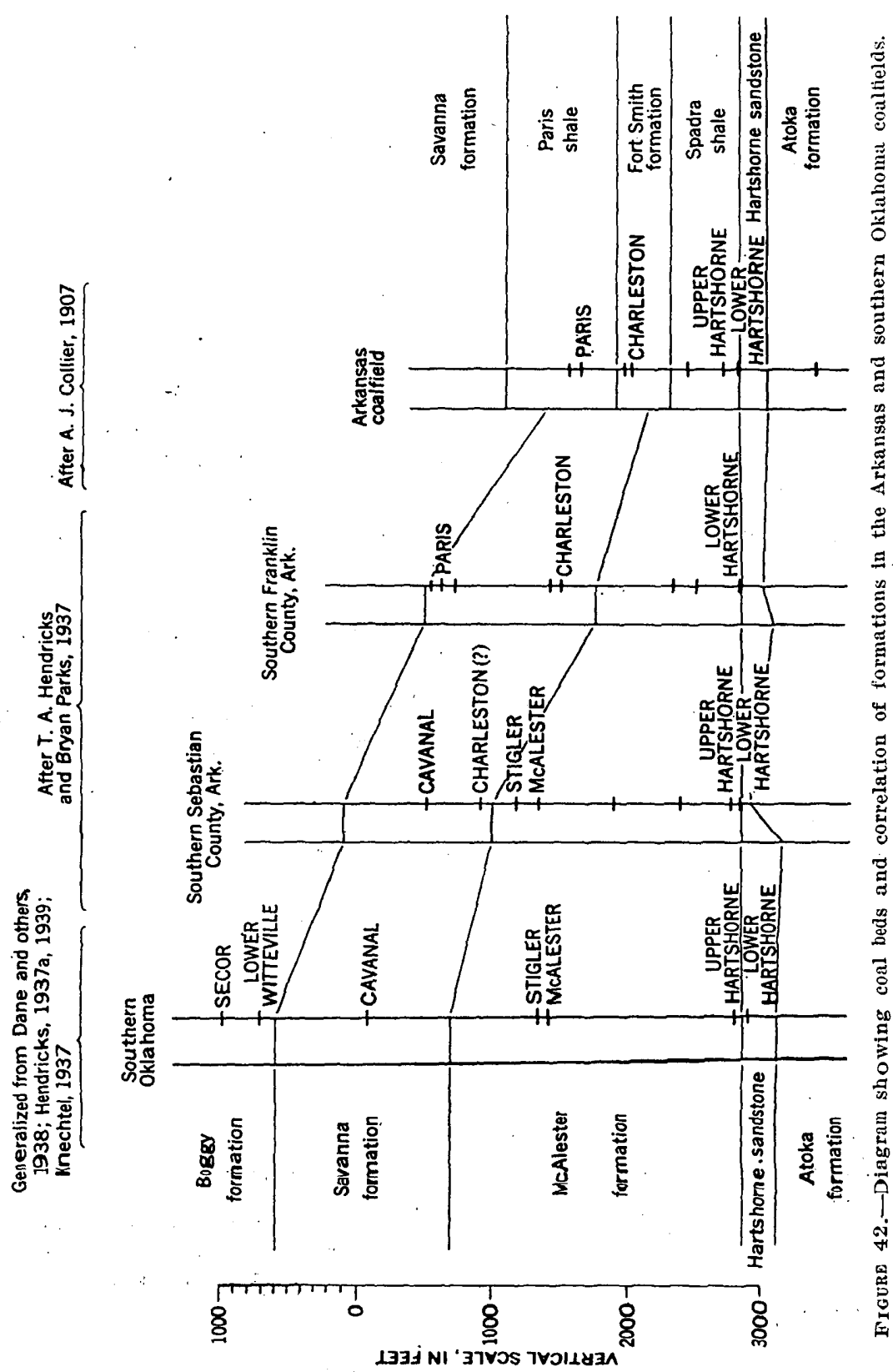


Hartshorne sandstone. It crops out the length of the southern boundary of the coalfield, and the horizon at which it occurs is present below the surface everywhere in the southern part of the field, except for the areas in Pittsburg, Haskell, northern Le Flore, and Sequoyah Counties where the coal bed and the overlying sediments have been uplifted by faults or anticlines and removed by erosion. Throughout much of this area the coal horizon is more than 3,000 feet below the surface. The location and classification of the reserves considered to be present in the Lower Hartshorne coal bed are shown on the generalized bed map, plate 17 .

TABLE 5.-Averages of analyses of Oklahoma coal by county and bed 1

[All analyses averaged are on the as-received basis]

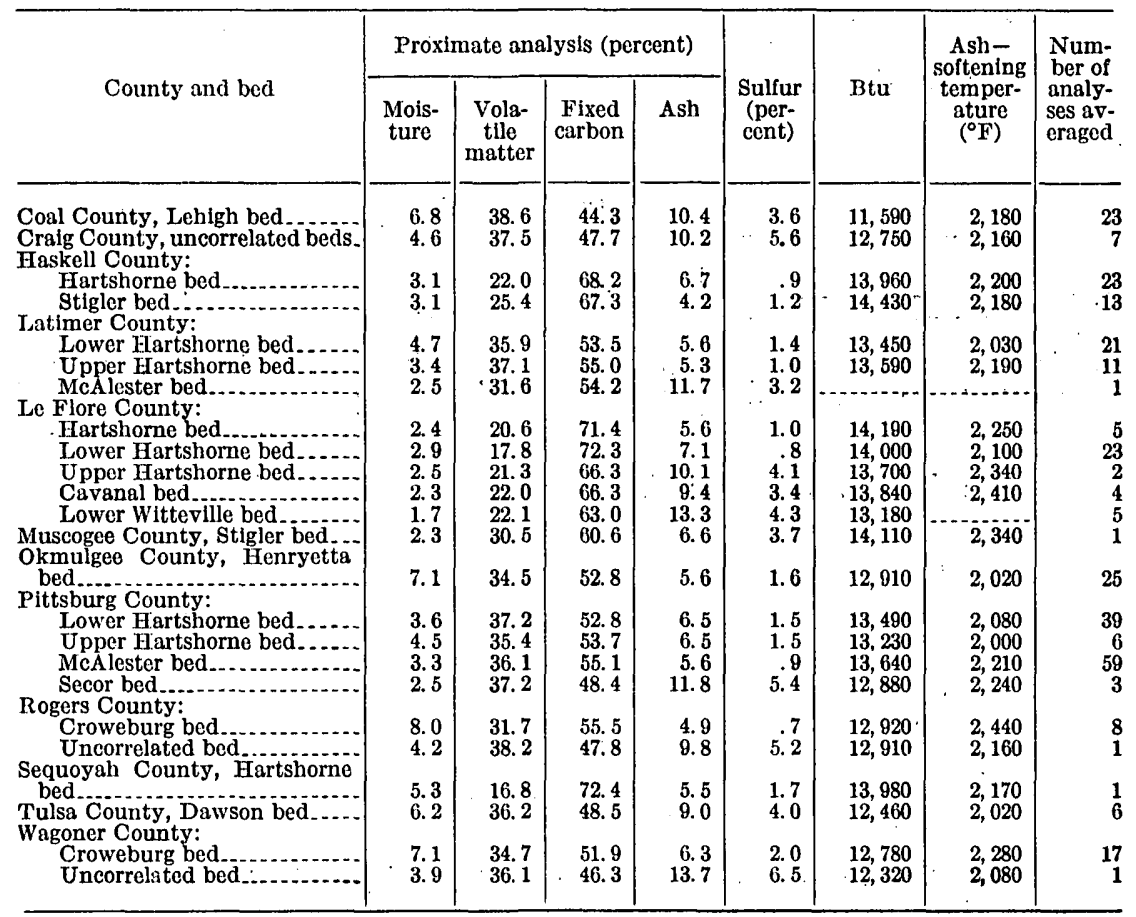

1 Figures given are simple averages of analyses of mine samples performed by the $U$. $S$. Bureau of Mines. Analyses of composite samples were not used. Many of the analyses averaged here appear in U. $\mathrm{S}$. Bur. of Mines Tech. Paper 411; others have been published by Dane and others (1938), Hendricks (1937a, 1939), Oakes (1944, 1952), Knechtel (1937, 1949), Oakes and Knechtel (1948), and Dunham and Trumbull (1955); others are unpublished. Many other analyses of Oklahoma coal made by the Oklahoma Geological Survey in cooperation with the Department of Chemical Engineering of the University of Oklahoma, none of which were used in the preparation of this table, will be found in Oklahoma Geol. Survey Bull. 51.

Because these are averages, the proximate analysis figures do not necessarily total 100 percent.

The number of ash-softening temperature determinations averaged is usually less than the number of analyses averaged, because this temperature determination was not performed for all samples.

Data for samples of beds, the names and correlations of which were stated by the sample collector to be unknown and which could not be established, are averaged together for Craig County. Devolatilization of the coal in different beds in northeastern Oklahoma can be expected to have progressed roughly the same amount, though ash and sulfur contents may of course vary widely between beds and the figures in those columns therefore may mean little. Unnamed and uncorrelated beds in the southern part of the coalfield were correlated where possible; but where the sampling location description did not permit certain correlation the analysis was disregarded. The samples of uncorrelated beds in Rogers and Wagoner Counties were collected in sec. 14, T. 24 N., R. 18 E. and the northeastern part of T. 16 N., R. 16 E., respectively. "Hartshorne bed" refers to both the Lower and Upper Hartshorne beds where they are mined as one bed in Haskell, Sequoyah, and a part of northern Le Flore Counties. 
The usual range in composition of mine, tipple, and delivered samples of the Lower Hartshorne and Hartshorne beds in several counties, on the dry-coal or moisture-free basis, is given in the table below.

In the Lehigh mining district in Coal and Atoka Counties, the Lower Hartshorne coal bed was formerly known as the Atoka coal. Its thickness on the west side of the Lehigh syncline reportedly averages 48 inches in the small area where it has been strip mined in T. 2. S., R. 10 E. Between this area and the mining district near the towns of McAlester and Hartshorne the rocks dip very steeply and are highly distorted, and there is little information on the coal bed through this distance.

Usual range in composition of Lower Hartshorne and Hartshorne coal

[Dry-coal or moisture-free basis. Data from U. 8. Bur. Mines, 1946, p. 42, 68]

\begin{tabular}{|c|c|c|c|c|}
\hline \multirow[t]{2}{*}{ : } & \multicolumn{4}{|c|}{ Counties } \\
\hline & Pittsburg & Latimer & Haskell & Le Flore \\
\hline $\begin{array}{l}\text { Moisture. } \\
\text { Volatile matter } \\
\text { Fixed carbon } \\
\text { Ash } \\
\text { Bulfur } \\
\text { Btu } \\
\text { Ash-softening temperature, }{ }^{\circ} \text { F }\end{array}$ & 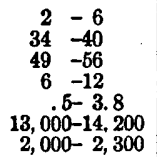 & $\begin{array}{r}2-5 \\
33-38 \\
53-61 \\
3-9 \\
1.0-1.9 \\
13,700-14,700\end{array}$ & $\begin{array}{r}2-6 \\
19-24 \\
69-75 \\
5-9 \\
\cdot 6-2.0 \\
14,000-14,800 \\
2,100-2,400\end{array}$ & $\begin{array}{rr}1 & -5 \\
16 & -21 \\
63 & -79 \\
4 & -15 \\
.6-4.2 \\
13,000-15,000 \\
1,900-2,400\end{array}$ \\
\hline
\end{tabular}

In the mining areas near the towns of Hartshorne, Wilburton, and Howe, and along much of the outcrop from Hartshorne eastward into Arkansas, the Lower Hartshorne bed ranges in general from $2 \frac{1 / 2}{2}$ to 6 feet in thickness. The dip is the main controlling factor in mining in this bed, because in many places where the coal is of minable thickness and purity, the dip is too high for economic mining by present methods. The bed has been mined intensively in places where the dip is low, as along the centers of anticlines and synclines. The most notable place is the wide bottom of the Hartshorne syncline in Tps. 4 and 5 N., Rs. 16 and 17 E., where the dip is less than $10^{\circ}$ over an area of about 10 square miles.

The Lower Hartshorne bed has been extensively prospected and mined by both underground and strip (Coal Age, 1953a) methods on the sides of the Milton and Backbone anticlines in northern Le Flore and eastern Haskell Counties. The thickness of coal in most of these mines is from 2 to 5 feet. In the part of this area north of the hervy dotted line on the bed map, plate 17, the Lower Hartshorne and Upper Hartshorne beds are so close together that they are generally mined as one bed. In the reserve estimates for that area they have also been considered as one bed, called for convenience the Hart- 
shorne coal bed. Parts of the Hartshorne bed were formerly known as the McCurtain and Panama beds.

The coal of the Lower Hartshorne and Hartshorne beds, in common with the other coal beds of the southern part of the Oklahoma coalfield, increases progressively in rank from west to east (fig. 37). In general, it is of high-volatile bituminous rank in Latimer County and westward, of medium-volatile bituminous rank in Haskell County and west of Wister in Le Flore County, and of low-volatile bituminous rank in the remainder of Le Flore County.

Carbonization studies by the U. S. Bureau of Mines in cooperation with the Oklahoma Geological Survey (Davis and Reynolds, 1941, 1942; Davis and others, 1944) have demonstrated that blends of low-volatile bituminous coal from the Hartshorne bed in northern Le Flore County with high-volatile bituminous coal from the McAlester and Henryetta beds can be coked in byproduct ovens to produce satisfactory blast-furnace coke. Large amounts of mediumvolatile bituminous coal mined from the Hartshorne bed near McCurtain, Haskell County, and low-volatile bituminous coal from the same bed in Le Flore County have been shipped to Texas, Utah, and California for blending with high-volatile bituminous coal to make metallurgical coke.

The detailed reserve estimates presented in table 8 show that 69 percent of Oklahoma's medium- and low-volatile bituminous coal reserves are present in the Lower Hartshorne and Hartshorne beds in Haskell and Le Flore Counties. Use of this coal for coking blends and the demand for it as a "smokeless" heating fuel make these reserves of great value.

\section{UPPER HARTSHORNE COAL BED}

The Upper Hartshorne coal bed occurs from a few feet to 50 feet above the base of the McAlester formation everywhere in the Okla;homa coalfield except in Haskell and northern Le Flore Counties, in part of which the Upper and Lower Hartshorne beds coalesce or are separated by only a few inches to a few feet of bony coal or coaly shale. Where this junction occurs, the top of the Upper Hartshorne coal bed has by redefinition been made the boundary between the Hartshorne sandstone and the McAlester formation (Oakes and Knechtel, 1948, p. 25), as previously discussed. In other areas the interval between the Upper and Lower Hartshorne coal beds is as much as 180 feet.

The Upper Hartshorne coal bed is very nearly coextensive with the Lower Hartshorne, but it is of minable thickness over a smaller area. In addition, high dips have so far prevented mining in both beds in 
some areas; and in other areas the Lower Hartshorne coal has been mined in preference, thus making mining in the Upper Hartshorne impractical. In the Lehigh mining district in Coal and Atoka Counties, the Upper Hartshorne coal is thin and of little or no value, and no reserves have been calculated for it in that area. Some mining in the bed has been done in Pittsburg County along the sinuous outcrop between the towns of Hartshorne and McAlester; near the Penitentiary fault northwest of McAlester; and near Blanco in T. 3 N., Rs. 14 and $15 \mathrm{E}$. The coal in these mines, in general, is from $2 \frac{1}{2}$ to $41 / 2$ feet thick and has a variable number of thin partings. Most of the mining in the Upper Hartshorne coal has been done in the vicinity of Wilburton, Latimer County, where the coal is from 3 to 5 feet thick and generally free from partings; and in T. 8 N., Rs. 24 , 25, and 26 E., on the south flank of the Backbone anticline in Le Flore County. Very small-scale strip mining of an 18- to 22 -inch coal bed that is thought to be the Upper Hartshorne has been reported in secs. 35 and 36, T. 18 N., R. 20 E., Cherokee County. No estimate of reserves has been made for this coal bed.

As shown in figure 39, the remaining reserves of coal estimated to be present in the Upper Hartshorne bed, exclusive of the area where it is considered jointly with the Lower Hartshorne bed, total 262 million tons, of which 147 million tons is of high-volatile bituminous rank, 5 milliọ tons is of medium-volatile bituminous rank, and 110 million tons is of low-volatile bituminous rank.

\section{MCALESTER (LEHIGH) COAL BED}

The McAlester coal bed occurs in the upper part of the McAlester formation, 1,400 to 1,600 feet above the Upper Hartshorne bed. Only a few thin coal beds of no value are present in the intervening strata. The location and classification of the reserves in the McAlester coal bed are shown on plate 17 .

The Lehigh coal bed in Coal County is about 1,200 feet above the Upper Hartshorne bed and generally ranges in thickness from $31 / 2$. to 5 feet. It crops out and has been mined on the flanks of the Coalgate anticline northeast and southwest of the town of Coalgate, and on the west side of the Lehigh syncline north and south of the town of Lehigh. The Lehigh bed occurs at about the horizon of the McAlester bed, and is generally considered to correlate with it, but because the coal beds have not yet been traced between the two areas and because both names are still in common use, the reserve estimates in this report are given separately. The Stigler coal bed of Haskell County may also correlate with the McAlester coal bed. This point is discussed in the next section of this report. Results of an investigation of the correlation of the McAlester coal bed by study of the 
preserved spores of the plants that formed the bed are contained in a recent report by Morgan (1955).

The McAlester coal bed has a combined length of outcrop in Pittsburg County of more than 60 miles, and its thickness there ranges, where known, from slightly less than 2 feet to about 5 feet. It has been mined on a very extensive scale in Pittsburg County and the mined thickness of coal is in most places from 3 to 4 feet. High dips. have in several places prevented mining or have restricted it to a zone close to the outcrop, especially on the northeastern end of the Savanna anticline in T. 4 N., R. 14 E. The McAlester bed commonly contains a number of partings or bands of impurities, most of which are thin and easily separable bands of pyrite. This is also characteristic of the Lehigh bed in Coal County.

The outcrop of the McAlester bed has been traced eastward from Pittsburg County across Latimer and Le Flore Counties to Arkansas. In the few places throughout that distance where the thickness of the bed is known it ranges from $11 / 2$ to 3 feet, and because of the scarcity of information only small reserves are thought to be present. What is believed to be the McAlester coal bed has been extensively drilled and strip mined on the southwest end of the Brazil anticline, in T. $6 \mathrm{~N}$., Rs. 21 and 22 E., Latimer County, where the thickness ranges from 20 to 26 inches:

The McAlester coal is of high-volatile bituminous rank, except for an extremely small tonnage of reserves near the outcrop in T. $6 \mathrm{~N}$, Rs. 23 and 24 E., Le Flore County. The coal there is considered to be of medium-volatile bituminous rank because it occurs east of the line established for use in this report to divide the two ranks. That line, however, is located largely on the basis of analyses of samples of other coal beds from localities several miles apart.

Many thin coal beds are present a short distance above the McAlester bed in Pittsburg County, but it has not been found possible to correlate these beds or to estimate reserves in them. An unnamed thin coal bed of no known value also occurs about 30 feet above the Lehigh bed.

\section{SṬIGLẸR COẠL BẸD}

The Stigler coal bed is present over broad areas in Haskell County, where it occurs a few feet above the Cameron sandstone member of the McAlester formation. The McAlester coal bed occurs at about the same horizon, and the possible correlation of these two coal beds: has been mentioned in several reports (Wilson and Newell, 1937, p. 85: “* * * The Stigler-McAlester coal ***"; Oakes and Knechtel, 1948, p. 27: "The well known Stigler (McAlester?) coal ***"; Knechtel, 1949, p. 48: "The Stigler coal bed *** [in northern Le Flore County] is tentatively correlated with the McAlester coal 
bed $* * * ")$. This correlation has not yet been definitely established, however, and in this report the two beds are treated separately.

Faulting and erosion on numerous folds have resulted in many separate outcrops of the Stigler coal bed. The bed appears at the surface in all parts of Haskell County except the western part, where the coal bed is at depth beneath the surface and its thickness is unknown. Nearly all the outcrops have been strip mined or drilled to determine the feasibility of strip mining. The thickness of the Stigler bed in Haskell County ranges from less than 14 inches to about 32 inches, and averages 16 to 20 inches where mined, except in the northern part of the county where over large areas its thickness ranges from 20 to 32 inches. In much of eastern Haskell County a thin coal bed from 2 to 6 inches thick occurs from about 25 to 44 feet above the Stigler bed, and is locally referred to as the rider vein.

In Le Flore County the Stigler bed crops out on the north side of the Milton anticline, and another outcrop of the bed between the Cavanal syncline and the Backbone anticline has been mapped eastward nearly to Arkansas. On a part of the latter outcrop thicknesses of from 15 to 23 inches have been measured. The Stigler coal is also present in T. 11 N., R. 23 E., Sequoyah County, where drilling and strip mining have shown that the bed averages from 18 to 22 inches in thickness. In strip mines in Tps. 10 and 11 N., Rs. 19 and 20 E., in the southern part of Muskogee County, the bed averages about 20 inches in thickness; but further north in that county, in Tps. 13 and 14 N., Rs. 18 and $19 \mathrm{E}$., its thickness is less than 14 inches.

Estimated remaining reserves in the Stigler bed total 154 million tons, of which 39 million tons is of high-volatile bituminous rank, 106 million tons is of medium-volatile bituminous rank, and 9 million tons is of low-volatile bituminous rank. About 75 percent of the total estimated remaining reserves is located in Haskell County.

Part of the production from this bed has been used in blends with coal from other beds in the manufacture of metallurgical coke. A representative analysis of coal from the Stigler bed in Haskell County is given in table 5 .

STIGUER(?) COAL BED

Hendricks (1939, p. 269), in discussing the geology of the McAlester formation in the Howe-Wilburton district in Latimer and Le Flore Counties, mentions a continuous coal bed "About 58 feet above the McAlester coal * * * that is probably the equivalent of the Stigler coal," and refers to this as the Stigler(?) coal.

What has been considered as the same bed crops out and has been drilled on the southwestern end of the Brazil anticline, in the central part of T. 6 N., R. 21 E., Latimer County, where it ranges in thickness from 16 to 20 inches. The bed has also been penetrated and reported 
to be 26 to 30 inches thick in a few drill holes near its outcrop in the southern parts of T. 6 N., Rs. 21 and 22 E. A coal bed that Knechtel (1949, p. 49) thought might correlate with this bed and also with the so-called rider vein a short distance above the Stigler bed in eastern Haskell County, is 15 to 16 inches in thickness and occurs about 80 feet above the Stigler bed in the northern part of T. 7 N., R. 26 E., the southern part of T. 8 N., R. 26 E., and the northwestern part of T. 7 N., R. 27 E., Le Flore County. In the present report the very small amount of reserves in this bed has been combined with the small reserves in the Stigler(?) bed.

Four thin coal beds are at least locally present between the Stigler(?) coal and the top of the McAlester formation, but it has not been possible to correlate these beds, and because their thickness is not known to exceed 14 inches, no further mention is made of them in this report.

\section{CAVANAL AND RELATED COAL BEDS}

The Cavanal coal bed occurs at about the middle of the Savanna formation, and is mined only in northern Le Flore County. It has been mapped on the south and east sides of Cavanal Mountain and on the north side as far west as T. 8 N., R. 24 E. In several small mines along this outcrop the bed averages 24 to 26 inches in thickness, although in a drill hole in sec. 23, T. 6 N., R. 24 E., the bed was 38 inches thick. Small reserves of coal are present in the Cavanal bed in the northwestern corner of T. 7 N., R. 23 E. What is thought to be the Cavanal bed also is exposed in extremely small areas in sec. 22, T. 10 N., R. 24 E., and in sec. 33, T. 10 N., R. 26 E. and sec. 4, T. 9 N., R. 26 'E., in extreme northern Le Flore County. No reserves were calculated for the latter two areas. The Cavanal bed is less than 14 inches thick in Haskell County.

The Cavanal coal is of medium-volatile bituminous rank. The composition of the bed, as shown by an average of the 4 available analyses, is shown in table 5 .

A thin bed slightly higher than the Cavanal has been mapped on the north side of Cavanal Mountain for a distance of about 9 miles southwestward from sec. 35, T. 8 N., R. 24 E.; and a thin bed slightly lower than the Cavanal is present from sec. 3 to sec. 12, T. 7 N., R. $25 \mathrm{E}$., and in the northeastern part of the town of Poteau. Both beds are about 26 inches in thickness where mined, and the very small amount of reserves in each of them is listed in table 8 (p. 372) as "unnamed bed above Cavanal" and "unnamed bed below Cavanal.". A still higher thin bed in which no reserves were calculated crops out in secs. 11, 14, 15, and 22, T. 7.N., R. 23 E., Le Flore County. 
A coal bed in Pittsburg County which Hendricks (1939, p. 61) tentatively referred to as the Cavanal(?) coal, and correlated with the Cavanal coal bed of Le Flore County, occurs in the southern part of T. 6 N., R. 15 E. This bed is reported to be 4 feet thick where it has been mined in secs. 28, 29, and 30 of that township, but it thins rapidly eastward and is only 1 foot thick at the east side of the township. Although the bed is vertical or nearly so, small reserves are thought to be present. Its thickness in the remainder of Pittsburg County is unknown.

Another coal bed in the Savanna formation which is reported to be about 2 feet thick and is considered to be younger than the Cavanal(?) bed has been mined in secs. 9,27 , and 28, T. 5 N., R. 15 E., west and south of the town of Krebs, Pittsburg County. What has been mapped as the same bed has also been mined to the south in sec. 18, T. $4 \mathrm{~N}$., R. 16. E. Lack of information has prevented the calculation of reserves in this bed.

A thin but persistent coal bed slightly younger than the Cavanal bed is present and has been mined on a small scale at several places in Muskogee County. The bed there is 120 to 200 feet below the Bluejacket sandstone member of the Boggy formation, and although Newell (Wilson and Newell, 1937, p. 53) called it the Lower Boggy coal, it is in the upper part of the Savanna formation as since redefined, and is probably the Rowe coal bed. Its thickness averages only 9 to 10 inches.

\section{LÖWER WITTÉVILLE COAL BED}

The Lower Witteville coal bed occurs in the upper part of the Bluejacket sandstone. It crops out and has been mined to a small extent high on the northeastern side of Cavanal Mountain, in T. 7 N., R. 25 E., northwest of the town of Poteau, Le Flore County. The coal bed is not present where the same horizon is exposed in the northeasten part of T. 7 N., R. 24 E., a few miles to the west, or in the extreme northwestern corner of Le Flore County. In a mine in sec. 15, T. 7 N., R. $25 \mathrm{E}$., the bed is more than 4 feet thick, but this thickness includes shale partings; the small amount of reserves in the bed has been calculated on the basis of a 22 -inch thickness of clean coal. The bed appears to contain much sulfur, but no analyses are available.

A coal bed of unknown thickness which may correlate with the Lower Witteville bed occurs near the base of the Boggy formation and has been mined north of the town of Savanna, in sec. 3, T. 4 N., R. 14 E., Pittsburg County.

\section{SECOÖ CÓAL BED}

The Secor coal bed occurs about 400 to 500 feet above the base of the Boggy formation, a short distance above the Bluejacket sand- 
stone member. The Boggy formation is widely exposed over the coalfield, and outcrops of the Secor coal bed are thus widely distributed. Local names by which the Secor bed has been known include Upper Witteville, Jones Creek, Massey, Blocker, Quinton, and Crowder.

The Secor bed crops out at numerous places in northeastern Pittsburg County and extreme western Haskell County. Its thickness there ranges from $131 / 2$ inches to slightly more than 3 feet, and averages approximately 2 feet in many small mines in T. 6 N., Rs. 15 and 16 E.; T. 8 N., R. 18 E.; and nearby areas. The bed also crops out and has been mined to a small extent at the northeastern ends of the Krebs and Kiowa synclines, respectively southwest and southeast of the town of McAlester, where its thickness is reported to be about 3 feet and the dips less than $25^{\circ}$. The Secor also occurs on both sides of the Sansbois syncline in southern Haskell County, where it is not known to exceed 14 inches in thickness, and high on the north, east, and south sides of Cavanal Mountain in northern Le Flore County, where past mining near the towns of Calhoun and Witteville found the coal to be from 2 feet to slightly more than 4 feet thick, but reportedly rather high in ash and sulfur. The Secor bed is about 28 inches thick where it has been strip mined on a small scale in Tps. 11 and 12 N., R. 18 E., McIntosh County. Where it has been mapped in central and northern Muskogee County it is more than 14 inches thick in only a small area.

On the basis of present information, estimated reserves remaining in the Secor bed as of January 1, 1953, total 168 million tons, most of which is located in the northeastern Pittsburg County-extreme western Haskell County area, and in Cavanal Mountain in northern Le Flore County. 'The Secor coal is of high-volatile bituminous rank except in the Cavanal Mountain area, where it is of medium-volatile bituminous rank. The average conposition, heating value, and ashsoftening temperature of the coal are shown in table 5 .

In northern Pittsburg County, an unknown number of coal beds are present within a few hundred feet both above and below the Secor, but they are apparently of minable thickness over only short distances. No reserve estimates were prepared for these beds.

Only a few thin and discontinuous coal beds are known to be present in the upper part of the Boggy formation. Coal is unknown in the Thurman sandstone and Stuart shale, which occur between the Boggy and the overlying Senora formation.

\section{COAL BEDS IN THE HENRYETTA MINING DISTRICT}

Three coal beds, all within the Senora formation, are present in the Henryetta-Morris mining district in Okmulgee County. The lowest of these, the Eram bed, has had no recorded production, and 
only about 120,000 tons of coal has been mined from the 5 small strip pits in the Morris bed. The higher Henryetta coal, however, has been mined intensively since 1902 and has been the source of approximately 17 percent of the total recorded coal production of the State.

\section{ERAM AND MORRIS COAL BEDS}

The Eram bed lies an undetermined distance above the base of the Senora formation. Drilling records show bed thicknesses ranging from 15 to 39 inches and averaging $271 / 2$ inches in 19 drill holes, but it is very probable that large amounts of parting and impure coal are included in these figures, and in the calculation leading to the estimate of 2.45 million tons of reserves of all categories in this bed, generally much smaller bed thickness figures were used. Several small team pits have been mapped along the outcrop, but no commercial production has been reported; nor has the outcrop area or the extension of the coal horizon northward and southward along the strike been mapped in detail. No analyses of this coal are available.

The Morris coal bed is 125 to 140 feet stratigraphically below the Henryetta bed and slightly less than 350 below the top of the Senora formation, and as far as is now known it is present only in a small part of Okmulgee County (pl. 17). In the area where it has been strip mined in the northwestern part of T. 13 N., R. 14 E., the bed ranges in thickness from 12 to 22 inches and averages 16 inches, and is without partings. Southward from that area the bed is variable in thickness and at most places is too thin to mine, except for a stripped area a few hundred feet in diameter in the NW1/4 sec. 6, T. 12 N., R. 14 E., where the exceptional thickness of 36 inches may be due to downhill slumping; and a small area in secs. 12 and 13 of T. 12 N., R. 13 E., where an abandoned drift mine, the only known attempt to mine this bed by underground methods, is located. Where observed near the dam impounding Lake Henryetta, about 7 miles south of the latter locality, the Morris coal bed is represented only by a coal zone a few inches thick. The extent and thickness of the bed northward from T. $13 \mathrm{~N}$. are completely unknown.

The estimate of 4 million tons of remaining reserves in all categories in this bed does not include coal present under the townsite of Morris. Two analyses on the as-received basis of samples of this bed from the strip mines near the town of Morris, made by a commercial laboratory, are as follows:

\begin{tabular}{|c|c|c|}
\hline Moisture - & $\begin{array}{r}\text { Percent } \\
4.46\end{array}$ & $\begin{array}{c}\text { Percent } \\
6.49\end{array}$ \\
\hline Volatile matter & 35.15 & 35.41 \\
\hline Fixed carbon & 54. 75 & 53. 70 \\
\hline Ash & 5.64 & 4.40 \\
\hline Sulfur & 1. 41 & 2. 40 \\
\hline
\end{tabular}




\section{HENRYETTA COAL BED}

The Henryetta coal bed occurs about 200 feet stratigraphically below the top of the Senora formation in southern Okmulgee County. Although the bed is of minable thickness over a relatively small area, it has been the source of approximately 17 percent of the total recorded: coal production of the State.

The thickness of clean coai in the Henryetta bed ranges from about 29 to $411 / 2$ inches and averages nearly 36 inches in the part of Tps. 11 and $12 \mathrm{~N}$. where it has been intensively mined by underground methods. Throughout much of the mining area a medial parting is present, and the southward thickening of this parting has prevented mining in and south of the southern part of T. 11 N., R. 13 E. In T. 12 N., R. 12 E., where three large highly mechanized (Coal Age, 1953b) drift mines were operating in 1953, this parting is absent or inconsequential. Except for the area disturbed by the Henryetta-Schulter faulted anticline, the location of which can be seen on the generalized coal-bed map, plate 17, as a long, narrow, light-colored projection into the mined area, mining conditions in this field are usually good: the roof and floor are excellent, the dip is low and uniform, and little gas is present. Six diamond-drill holes located on the west, or downdip, side of the mining area found coal thicknesses of from 35 to 39 inches at depths of 365 to 630 feet, indicating that large reserves are available for future mining.

The Henryetta coal is of high-volatile $A$ and $B$ bituminous rank. The minimum, maximum, and average composition of the bed shown by analyses of 46 samples from this mining area are as follows (U. S. Bureau of Mines, 1928; p. 20-21; Moose and Searle, 1929, p. 26-30; Dunham and Trumbull, 1955, table 1):

\begin{tabular}{|c|c|c|c|}
\hline & $\begin{array}{l}\text { Minimum } \\
\text { (percent) }\end{array}$ & $\begin{array}{c}\text { Average } \\
\text { (percent) }\end{array}$ & $\begin{array}{l}\text { Maximumum } \\
\text { (percent) }\end{array}$ \\
\hline Moisture & 4.9 & 7.2 & 8.9 \\
\hline Volatile matter & 31.9 & 34.4 & 36.8 \\
\hline Fixed carbon & 49.4 & 52.8 & 55.4 \\
\hline Ash & 3.9 & 5.5 & 9.5 \\
\hline Sulfur _ & .7 & 1.8 & 3. 7 \\
\hline Btu_... & 12,350 & 12,860 & 13,450 \\
\hline
\end{tabular}

Twenty determinations made by the U. S. Bureau of Mines of the ash-softening temperature of this coal average $2,120^{\circ} \mathrm{F}$ and range from $1,950^{\circ} \mathrm{F}$ to $2,420^{\circ} \mathrm{F}$. Estimated remaining reserves in the Henryetta bed in this mining area total about 243 million tons.

North across the Deep Fork of the Canadian River from the mining area described above, the Henryetta coal bed is extremely impure, and near the southern boundary of. T. $13 \mathrm{~N}$. it can only be described as a carbonaceous shale or carbonaceous sandstone. Farther north the coal again becomes of minable thickness and purity. Its thickness averages 
nearly 25 inches where it has been strip mined in the area between the towns of Morris and Okmulgee and nearly 17 inches for a distance of $21 / 2$ miles along the outcrop in a part of T. 14 N., R. 14 E. Estimated remaining reserves in these two areas total over 27 million tons, nearly all of which is in the 14- to 28 -inch thickness category.

The Henryetta bed has recently been proved to be the same bed as the Croweburg (Broken Arrow) bed of northeastern Oklahoma and southeastern Kansas.

\section{COAL BEDS IN NORTHEASTERN OKLAHOMA}

As shown by the column of plate 16 headed "Northeastern Oklahoma," a rather large number of named coal beds occur in that part of the State. A few of these beds, notably the Croweburg (Broken Arrow) and the Dawson, are relatively thick for long distances and have been well known and extensively mined for many years. Most of the remaining beds are on the average much thinner, and are so variable in thickness at the outcrop as to be in some places discontinuous or nearly so. Nevertheless some of them have been mined at a great number of small operation. Nearly all the beds recur persistently over long disstances. No detailed map has been made of the outcrops of many of these thinner beds, nor are there many closely spaced thickness measurements available for them. Because of this no meaningful estimates of reserves in these beds could be made, even though some thousands of tons of coal are mined from them each year.

Of the 14 named coal beds or beds at the same horizon as named beds of southern Kansas, reserve estimates have been made only for the Croweburg (Broken Arrow) bed, for the Dawson bed, for uncorrelated beds in very small areas near the surface in northeastern Rogers County, and in a rather large area of relatively thick coal which closely spaced drilling has indicated is present at depth in Craig County.

In the following discussion, the coal beds of northeastern Oklahoma are described in order from oldest to youngest, and for convenience are divided into two groups: Those that occur below the well-known Fort Scott limestone and are therefore of Krebs and Cabaniss (that is, Cherokee) age, and those that occur above the Fort Scott and are of Marmaton and Missouri age.

\section{COAL BEDS BELOW THE FORT SCOTT LIMESTONE}

Recent field investigations have resulted in the correlation of coal beds between the numerous large and small strip mines scattered through northeastern Oklahoma, and have established the equivalence of these coal beds with the generally thicker and better known beds of the Cherokee group in the southeastern Kansas coalfield. Much of this work has been done by C. C. Branson, director of the Oklahoma 
Geological Survey, and a number of graduate students at the University of Oklahoma working under his direction. The information in the following discussion, except where stated otherwise, is derived from the work of this group.

The correlation diagram, plate 16, shows that the Krebs and Cabaniss groups, which in northeastern Oklahoma contain all the coal beds below the Fort Scott limestone, also contain all the coal beds in the southern part of the Oklahoma coalfield. Though several of the northeastern Oklahoma coal beds have been traced as far south as the Arkansas River, correlation of them with the coal beds in the southern part of the field has not yet been established.

The lowest coal bed of northeastern Oklahoma, the Riverton, lies between the Warner (Little Cabin) sandstone member and the base of the Krebs group, and is named from the Riverton coal of Kansas, which occurs in the same sequence. It has been found at several localities in Craig County, but is not known to exceed 14 inches in thickness.

Higher in the section, between the Spaniard limestone member of the Savanna and the Bluejacket sandstone member of the Boggy formation, the Rowe and Drywood (Bellamy) coal beds persist for long distances southward into Oklahoma. The Rowe bed has been stripped at a number of localities as far south as Muskogee County, and its thickness is at most places less than 14 inches, though it is a maximum of 18 inches thick in northwestern Mayes County and is reported to be 26 inches thick in T. 17 N., R. 18 E., Wagoner County. The Drywood coal is discontinuous but persistent in Oklahoma, and though it is thin it has been mined west of the town of Bluejacket in northeastern Craig County and for local use at several other places.

A coal bed that averages 20 inches in thickness where mined in the southern part of T. 28 N., R. 20 E., Craig County, has been correlated by Howe (1951, p. 2091) with the well-known Weir-Pittsburg coal of southeastern Kansas. This is probably the coal bed long known as the Cherokee (Shannon and others, 1926, p. 39, pl. 23). It is now referred to in Oklahoma as the Pawpaw bed. Much strip mining and some underground mining have been done in this bed at many places from the vicinity of the Kansas State line south to T. 16 N., R. 17 E., in southern Wagoner County. The thickness of the bed is 18 to 23 inches in most places, and is reported to range from 10 to 48 inches. Thus it is a relatively thick bed compared with others above and below it; but not enough detailed outcrop mapping and closely-spaced thickness 'measurements are available to calculate a meaningful estimate of reserves.

Three coal beds occurring in northeastern Oklahoma between the Pawpaw (Weir-Pittsburg) bed and the Croweburg (Broken Arrow) 
bed have been given the names of their Kansas correlatives. From oldest to youngest these are the Pilot, which is known to be present as far south as T. 18 N., R. 16 E., but is not known to be more than 6 inches thick; the Mineral, which occurs and is mined in Tps. 28 and 29 N., R. 20 E. (Howe, 1951, p. 2091), where it is from 14 to 22 inches thick; and the Fleming, which is mined in Oklahoma only in an area west of the town of Welch, in northeastern Craig County.

Above these beds and a short distance beneath the Verdigris limestone member of the Senora formation lies the well-known Croweburg (Broken Arrow) coal bed, the occurrence of which has been described in detail by Oakes (1944). The recent division of the rocks of Cherokee age into the Krebs and Cabaniss groups places the Croweburg bed at about the middle of the Cabaniss group in Oklahoma. It has been mapped from the northern edge of the terrace and alluvial deposits of the Arkansas River in sec. 36, T. 18 N., R. 14 E., northeastward through the northwestern corner of Wagoner County, past Claremore in Rogers County, to the top of T. $22 \mathrm{~N}$. The Broken Arrow bed, as it was formerly referred to, has been definitely correlated with the Croweburg coal bed of Kansas and with the Henryetta bed of Okmulgee County. The outcrop, mined areas, and areas where reserves are thought to be present are shown on plate 17 .

The Croweburg bed has been strip mined to an overburden thickness of about 35 feet almost continuously through Tps. 18 and $19 \mathrm{~N}$., where its thickness ranges from 18 to 30 inches. In general the bed in this area becomes thinner toward the north, averaging about 24 inches in thickness in T. 18 N., about 20 inches in T. 19 N., and about 18 inches in the southern part of T. 20 N., R. 15 E. The outcrop of the bed is hidden in the central part of the latter township by alluvium in the valley of Verdigris River. The exact thickness of the bed is not known for the next 9 miles northward along the outcrop, and little mining has been done there. In T. $22 \mathrm{~N}$. the uniformly low dip of the coal bed and the gently rolling topography have combined to give the outcrop of the Croweburg bed a somewhat intricate pattern; this increase in the length of the outcrop has resulted in widespread strip mining in this township. A small amount of mining has been done in the bed in T. 23 N., R. 17 E., but it is only 12 inches thick in one place in that township, and no reserves are considered to be present in the bed there.

Northward from T. $23 \mathrm{~N}$. the Croweburg bed is reported to be as thin as half an inch, and to be mined where it is as thick as 19 inches. $A_{S}$ is true of most of the coal beds in northeastern Oklahoma, not enough detailed information about thickness, purity, and extent is available to make possible an evaluation of reserves, even though large tonnages of coal of minable thickness may eventually be proved to be present. 
The Croweburg coal is high-volatile bituminous in rank. The average composition on the as-received basis of the Croweburg coal in Oklahoma, based on 25 analyses made by the U. S. Bureau of Mines, is shown in table 5. On the basis of present thickness information, all of which is restricted to a zone within about one-eighth of a mile of the outcrop or mined areas, remaining reserves in the bed are estimated to total about 101 million tons.

The Bevier coal bed of southern Kansas becomes thin within a short distance southward into Oklahoma, and it is not known to be mined there. The next higher coal bed lies: only a few feet below the Breezy Hill limestone member, and has been named the Iron Post coal by Howe (1951, p. 2092). In Oklahoma it has often been referred to as the Fort Seott coal, and it is not to be correlated with the Mulky coal of Kansas, which lies above the Breezy Hill and does not extend into Oklahoma.

The horizon of the Iron Post coal has been mapped by J. H. Warren, of the Oklahoma Geological Survey, from the southwestern corner of T. 19 N., R. 15 E., northwestern Wagoner County, to the Kansas State line. Observed thicknesses of the bed in this distance range from 2 inches in sec. 36, T. 19 N., R. 14 E., to 14 to 16 inches in T. 22 N., R. 15 E.; T. 24 N., R. 17 E.; and T. 26 N., R. 18 E. The bed may be more than 14 inches thick for a distance of about 20 miles northward from the Catoosa area, but not enough detailed thickness information is available for making reliable reserve estimates. Undoubtedly a modest amount of remaining reserves is present in the bed. The Iron Post coal is mined at a number of places between T. 23 N., R. 17 E., and Kansas, but it is less than 14 inches thick at several of these operations.

Core drilling done during 1917-22 disclosed the presence in Tps. 28 and 29 N., Rs. 18 and 19 E., northwestern Craig County, of a coal bed at depths ranging from about 250 feet at the east side of R. 19 E. to about 550 feet at the west side of R. 18 E. Its maximum thickness is slightly over 4 feet. No coal beds of this thickness have been seen at the surface to the east of this area, and the correlation of this thick bed is unknown.

The Fort Scott. limestone crops out on the eastern side of R. 19 E. at this latitude, and the combined thickness of the Krebs and Cabaniss (Cherokee) groups thereabouts is 400 to 500 feet. It can therefore be surmised that this coal bed must be somewhere near the middle of the rocks of Cherokee age. Inasmuch as the Weir-Pittsburg coal of Kansas is fairly near the middle of the Cherokee group of Kansas, and is about 44 inches thick in the southern part of the southeastern Kansas coalfield (Pierce and Courtier, 1937, p. 66 and fig. 2), it may be that the thick coal bed of Craig County will in 
the future be shown to be a thick local development of the WeirPittsburg bed.

\section{COAL BEDS ABOVE THE FORT SCOTT LIMESTONE}

Four named coal beds, 1 of Marmaton and 3 of Missouri age, are present in northeastern Oklahoma, but of these only the Dawson is of more than stratigraphic or local economic value. Except for the southward extension of the outcrop of the Dawson bed, no coal beds of Marmaton or younger age are known to be present in rocks of Pennsylvanian age south of the Arkansas River. More detailed information about these coal beds is contained in recent reports of M. C. Oakes $(1940,1952)$ and C. M. Cade (1953).

The Lexington coal bed occurs in Oklahoma at the top of the Labette shale, and is only 1 or 2 inches thick where it has been found in Tps. 28 and 29 N., R. 18 E., northwestern Craig County. It is therefore only of stratigraphic interest.

The Dawson coal bed, also known as the Tulsa bed, occurs in the Seminole formation, which is of lowermost Missouri age. It has been mapped from the Okmulgee-Tulsa County line near the center of T. 16 N., R. 12 E., northward through Tulsa and Collinsville to the north line of T. 22 N., R. 14 E., and extends north to the Kansas State line. The outcrop of the bed is straight in overall configuration, and the westward dip is consistently low. The outcrop, mined areas, and areas where reserves are present in the Dawson bed are shown on plate 17.

The Dawson bed is fairly uniform in thickness and averages about 20 inches through much of Tps. 22 and $23 \mathrm{~N}$., and it ranges from 18 to 30 inches in thickness in the N1/2 T. 19 N. and the S1/2 T. 20 N., near and within the limits of the city of Tulsa. In these two areas it has been extensively mined, mostly by stripping but also, in the Tulsa area, by slope and drift mines. Between these two areas and farther north and south along the outcrop the bed is irregular in thickness and generally thinner, being at many places less than 14 inches in thickness, and it has been mined there in only a few small and isolated areas. Just south of the mining area in and near Tulsa the bed is hidden by alluvial and terrace deposits of the Arkansas River valley, and to the north it is also masked for shorter distances by the alluvium in the valleys of Bird Creek and Caney River. Near the Kansas State line, in Tps. 27, 28, and 29 N., the Dawson coal is less than 1 foot thick. Although logs of wells drilled for oil and gas indicate the presence underground of the Dawson bed at many places, they do not give reliable information as to its thickness.

The Dawson coal, in common with the other coal beds of northeastern Oklahoma, is of high-volatile bituminous rank. The average 
composition, heating value, and ash-softening temperature of the bed are shown in table 5. On the basis of present information, all of which is restricted to a zone very close to the outcrop and mined areas, it is estimated that the remaining reserves in the Dawson bed as of January 1, 1953, total about 49 million tons.

A coal bed that at most places is less than 1 or 2 inches thick and is at about the horizon of the Cedar Bluff coal of Kansas occurs about 40 feet below the top of the Coffeyville formation in the northwestern. Nowata-southeastern Washington County area in Oklahoma. One or more thin coal beds from 1 to $31 / 2$ inches thick are also common in the topmost 10 feet of that formation. 'The thickest reported' ocurrence of any of these coal beds is in sec. 30, T. 27 N., R. 15 E., Nowata County, where one of the upper coal beds is 1 foot thick. The Cedar Bluff coal is not known as far south as Tulsa County, but one or more thin streaks of coal are present in the upper 3 feet of the. Coffeyville formation there.

The still higher Thayer coal bed in the lower part of the Chanuteformation extends entirely across the northern part of Washington: County and has been seen in place as far south as sec. 12, T. 21 N., R. 11 E., southeastern Osage County. It takes its name from the Thayer coal bed of Kansas, with which it is correlated.

The Thayer bed is about 6 inches thick and relatively free of impurities in sec. 12, T. 25 N., R. 12 E., and reaches a maximum observed' thickness of 18 inches but has several shale partings in sec 1 of that township. The bed is commonly less than 1 or 2 inches thick, however, and though its persistence makes it stratigraphically important, it is not considered to contain any reserves.

\section{COAL IN CARTER COUNTY}

One bed of coal of Pennsylvanian age is present in T. 5 S., R. 2 E., Carter County, on the southwestern side of the Arbuckle Mountains, an area distinctly separated both geologically and geographically from the main coalfield of eastern Oklahoma. Tomlinson (1929, p. 45) states that it occurs just below his Daube limestone memberof the Hoxbar formation, and that this is the only bed of coal known in the Ardmore basin; but more recent information indicates that more than one coal bed is present.

The outcrop of a coal bed, as shown in U. S. Senate Document 390 (pl. 11), extends for $4 \frac{1}{2}$ miles southeastward from a point slightly south of the center of sec. 8, T. 5 N., R. 2 E., to a point near the centerof $\mathrm{N}_{1} / 2$ sec. 35 in the same township. That report also states (p. 360) that where mining has been carried on near the southeastern corner of sec. 8 , the bed- 
is 3 feet 4 inches thick, and separated by a variable parting of shale 3 to 5 inches thick. The coal has been prospected at a number of places along the outcrop and its thickness reported to be practically as found in the mine.

The Ardmore coal has not been analyzed. In physical character it is closely related to that of the Lehigh coal, except that it is probably a little softer. "In the folding of the strata the coal in the mine above referred to has been fractured and in places small fissures formed.

According to Tomlinson (1929, p. 45), an attempt made in 1890 to mine the coal at this locality was unsuccessful. Tomlinson's map (pl. 20) shows northeast dips ranging from $35^{\circ}$ to $42^{\circ}$ in the area where the coal bed outcrops. Shannon and others (1926, p. 59) state that the coal is not generally found under favorable conditions for mining, but production of 828 tons in the year ending June 30, 1904, is recorded from a mine with a slope length of 1,000 feet (Taff, 1905, p. 399).

No estimate of reserves has been made for this coal bed because more detailed information is lacking.

\section{LIGNITE IN CIMARRON COUNTY}

Impure lignite from 12 to 18 inches thick has been observed at several localities in Tps. 3 and 4 N. of parallel $36^{\circ} 30^{\prime}$, R. 1 E., Cimarron meridian, Cimarron County, at the extreme western end of the Oklahoma panhandle. The lignite is of Cretaceous age and is reported by Rothrock $(1925$, p. 45,86$)$ to be near the top of the Purgatoire formation and by Schoff and Stovall $(1943$, p. 38, 89) to be in the overlying Dakota sandstone. The information given here is taken from those two reports.

Two drifts which have never been worked expose the lignite in secs. 19 and 20, T. 4 N., R. 1 E. At the larger of these two drifts, near the center of sec. 19, the lignite is 18 inches thick. An analysis made by A. C. Shead in the laboratories of the Oklahoma Geological Survey of a sample of the lignite from this locality is as follows:

Moisture 12. 64

Volatile matter 31.25

Fixed carbon. 35.34

Ash 20. 77

Sulfur .55

Btu: 7,550

Lignite 12 inches thick has been stripped in sec. 32, T. 4 N., R. 1 E.; and in sec. 33 of the same township a bed of about the same thickness but containing a large amount of shale and thin sandstone lenses is exposed. In the NW1/4 sec. 5, T. 3 N., R. 1 E., a bed of lignite is 18 inches thick, and can be traced for more than a quarter of a mile along the bed of South Carrizo Creek, a tributary of the Cimarron River. An analysis made by A. C. Shead in the laboratories of the Oklahoma 
Geological Survey of a sample of the lignite from this: area, where it was being mined for local use in 1943 , is as follows:

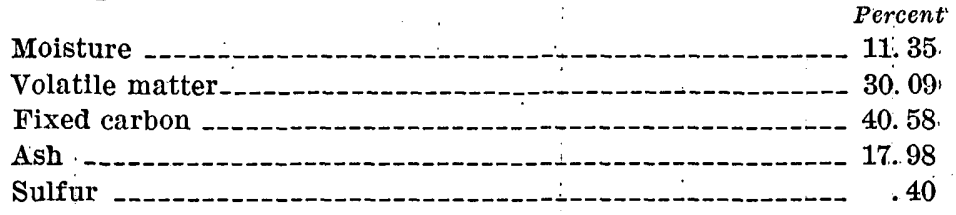

Btu: 8,500

Though the lignite occurs at about the same horizon in each of thesefive exposures, it has not been traced from one to another, and may be present only in small lenses. The high ash content and the thinness: and apparently small extent of this material indicate that it is most likely not worthy of commercial exploitation at present. Because of this thinness where it has been observed and the lack of detailed information on its occurrence and extent, no estimate of reserves has: been prepared for it.

\section{COAL MINING IN OKLAHOMA PRODUCTION}

The presence of coal in what is now Oklahoma has been known since at least 1821, when Thomas Nuttall's journal of several excursions: across the coalfield was published (Nuttall, 1821, p. 146-177; Drake, 1898 , p. 327), but mining on a commercial scale did not begin until the Missouri-Kansas-Texas Railroad was built through McAlester in 1872 (Taff, 1902 , p. 386-7; 1905, p. 397-8). In the following year branch lines were built to haul coal from nearby mines to the main line at McAlester, and the beginning of commercial-scale mining in each succeeding part of the coalfield was similarly made possible by the arrival of railroad lines.

The Choctaw, Oklahoma, and Gulf Railroad was built eastward from South McAlester along the southern limit of the coalfield soon after 1872, as a consequence of which mines were opened at Hartshorne, Wilburton, Howe, and other points; and the later extension of this line eastward to Memphis, Tenn., and westward across Okla-homa widely increased the market for the coal. The St. Louis-San Francisco Railway was built across the east side of Indian Territory about 1885, followed by the building there of the Kansas City Southern Railway, which gave transportation north to Kansas and Missouri and south to the Gulf of Mexico at Port Arthur, Tex. In 1891 the steadily rising production first reached a million tons a year. (Seefig. 43 and table 6 .) These 4 railroad lines were the only ones operating in the coalfield in 1897, at which time 18 companies and individuals were mining coal on a commercial scale, but soon after the turn of the century many main and branch lines were built through much. 


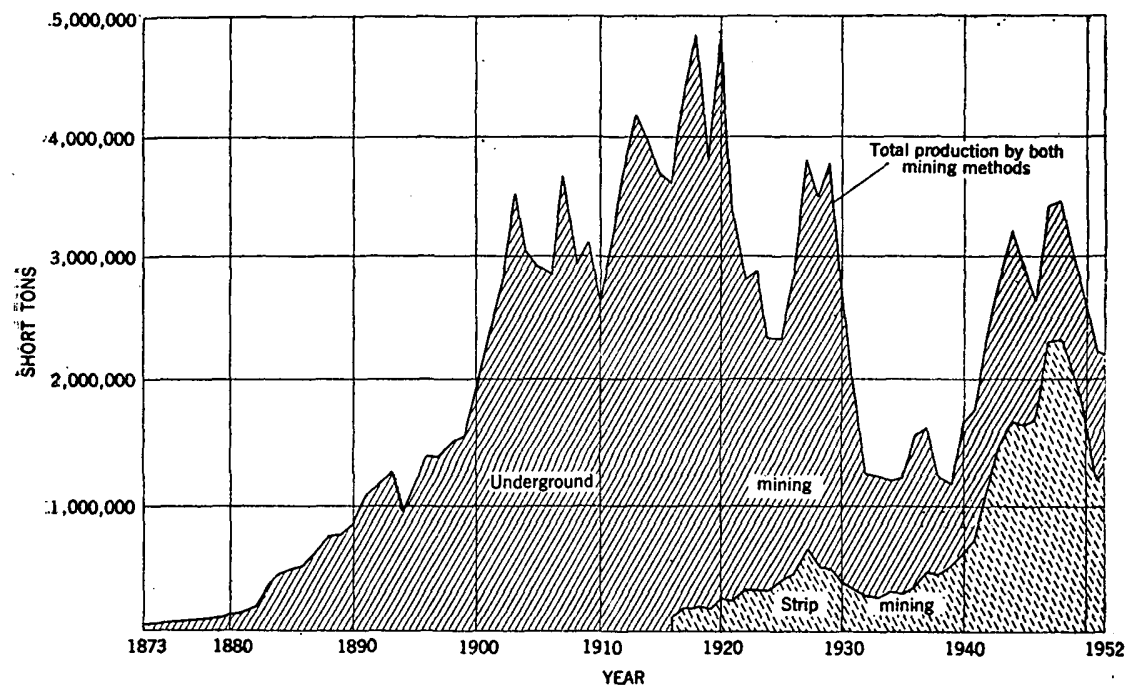

Figurb 43.-Coal production in Oklahoma, 1873-1952.

of the remainder of the coalfield, including the Henryetta mining district, in which production began in 1902. By 1903, production from the 117 mines throughout the coalfield exceeded $31 / 2$ million tons.

Production of coal by strip mining was not important in Oklahoma before 1920, when only 5 percent of the record State total production of 4.85 million tons was mined by that method. Nearly every year since, however, and especially in the period 1940-49, this method of mining has contributed a larger share of the State's production: in 1930, 13 percent; in 1940, 38 percent; in 1943, 51 percent; and in 1949, a peak of 68 percent (fig. 43 ). This relatively recent quantity production of coal by strip-mining methods has come mostly from the counties north of the Canadian River, from Sequoyah County, and from much of Haskell County. (See production figures for individual counties, table 6 .)

The cumulative reported production of coal in Oklahoma through 1952 is about 166.45 million tons, of which nearly 28 million tons, or 16.8 percent, has been strip mined. In $1952,1.31$ million tons, or about 60 percent of the total State production of 2.19 million tons in that year, was produced from 19 strip mines, and the remainder from 28 underground operations. In 1952 Oklahoma ranked fifteenth among coal-producing States, after Missouri and before Montana. Production of coal from nearby States in that year was as follows:

\section{Tons}

Missouri $2,954,450$

Oklahoma $2,193,409$

Kansas $2 ; 028,601$

Iowa $1,380,733$

Arkansas 
Much of the coal mined in Oklahoma in recent years has been blended with other coal and used in the manufacture of metallurgical coke. In 1950, 1,021,540 tons, or 38 percent of the total State production for that year, was used in high-temperature coke ovens: 796,359 tons in Texas, 207,795 tons in Utah, and 17,386 tons in other States. In 1952, 987,739 tons, or 45 percent of total Oklahoma production for that year, was used in coke ovens: 792,425 tons in Texas, 122,930 tons in Utah, and 72,384 tons in California (U. S. Bureau of Mines, 1954, p. 208-209).

\section{MINING METHODS}

The trend toward strip mining is more pronounced in Oklahoma than in the United States as a whole. The 19 strip mines operating in 1952 were equipped with 23 shovels and 11 draglines, and produced 59.9 percent of the State's total output, which was far above the 23.3 percent of national output produced by stripping in that year (U. S. Bureau of Mines, 1954). Average production of each strip pit in Oklahoma in 1952 was 69,165 tons; for each strip pit in the entire nation, it was 66,287 tons. The productivity of the average number of 503 men working in the strip mines in the State averaged 13.09 tons per man-day during that year; the national average was 16.77 tons per man-day.

Notwithstanding the importance of strip mining in recent years, 83.2 percent of the State's cumulative production has been mined by underground methods. Most of the underground operations have been slope mines, partly because in much of the large and intensively mined southern part of the coalfield the coal occurs on the flanks of folds, so that the coal beds at the outcrop have relatively high dips. In most of the slope mines the main entry is driven directly down the dip, generally paralleled by one or more air courses, and a number of horizontal cross entries are driven on each side, from which rooms or panels are driven up or down dip. Many shaft mines have also been operated, mainly where the coal is at depth in the more level central part of synclines, but also in areas such as the vicinity of Henryetta and in the Dawson bed near Tulsa, where a uniformly low dip has resulted in the coal being only a few hundred feet underground at a great distance from the outcrop. 'The far smaller number of drift mines have been located mainly where gently dipping coal beds are exposed in hillsides, such as in the hilly country in Le Flore County in the southeastern corner of the coalfield and in the Henryetta mining district. In the Henryetta district, of the 57 underground mines known to have been operated, 21 were opened by shafts, 21 by drifts, and 15 by slopes. 


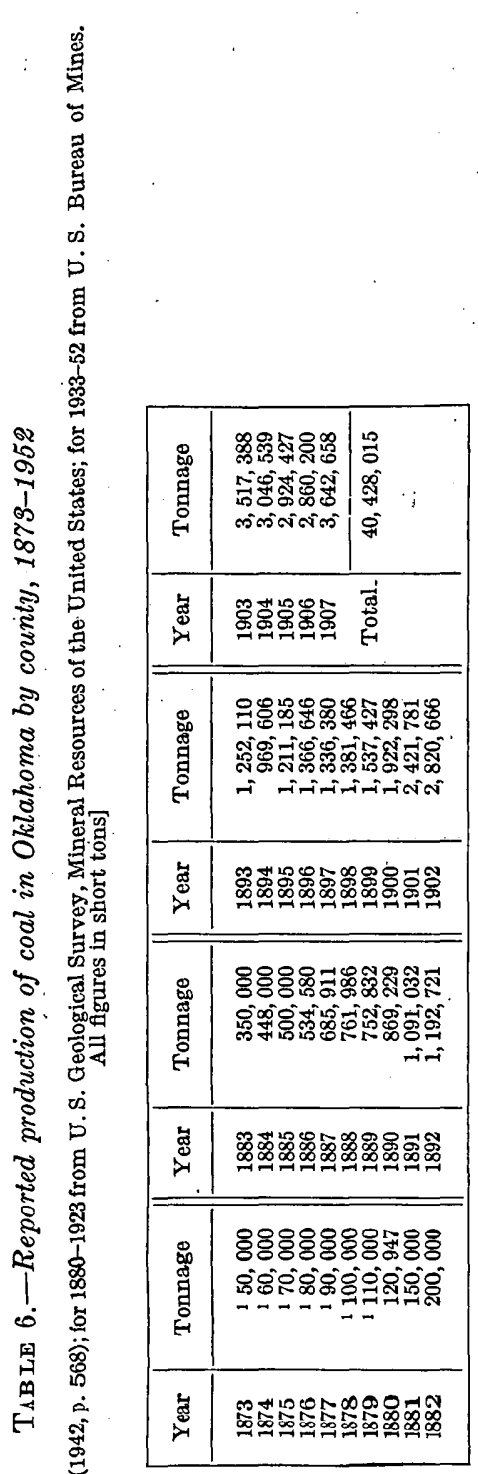

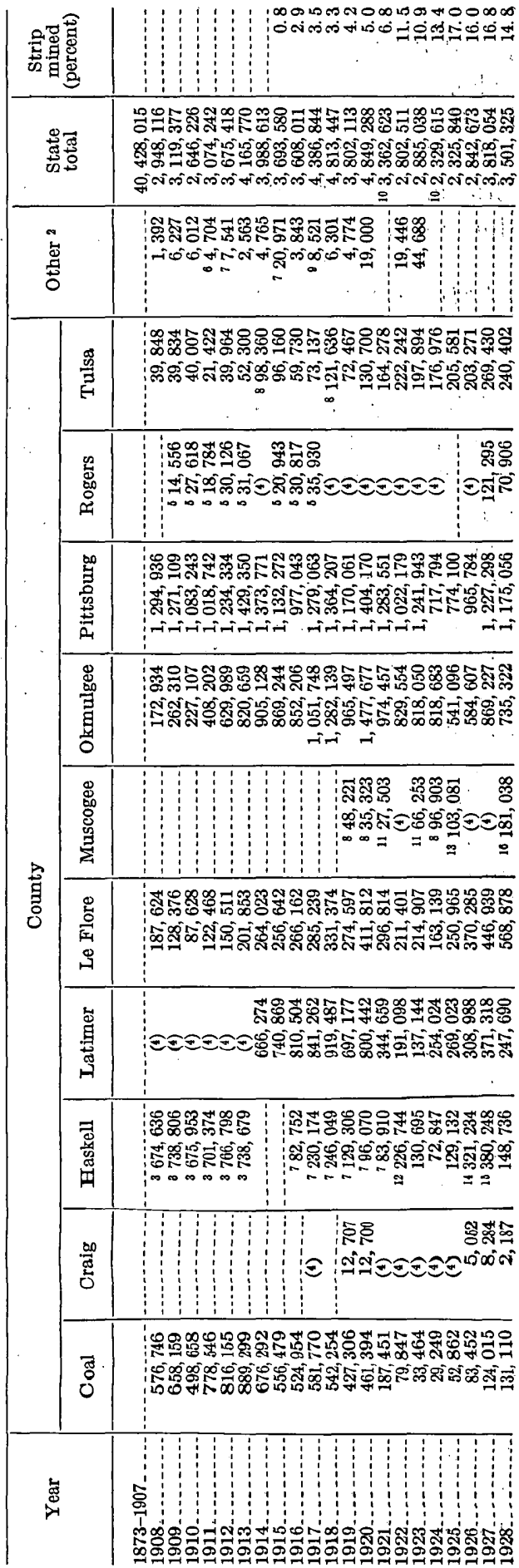




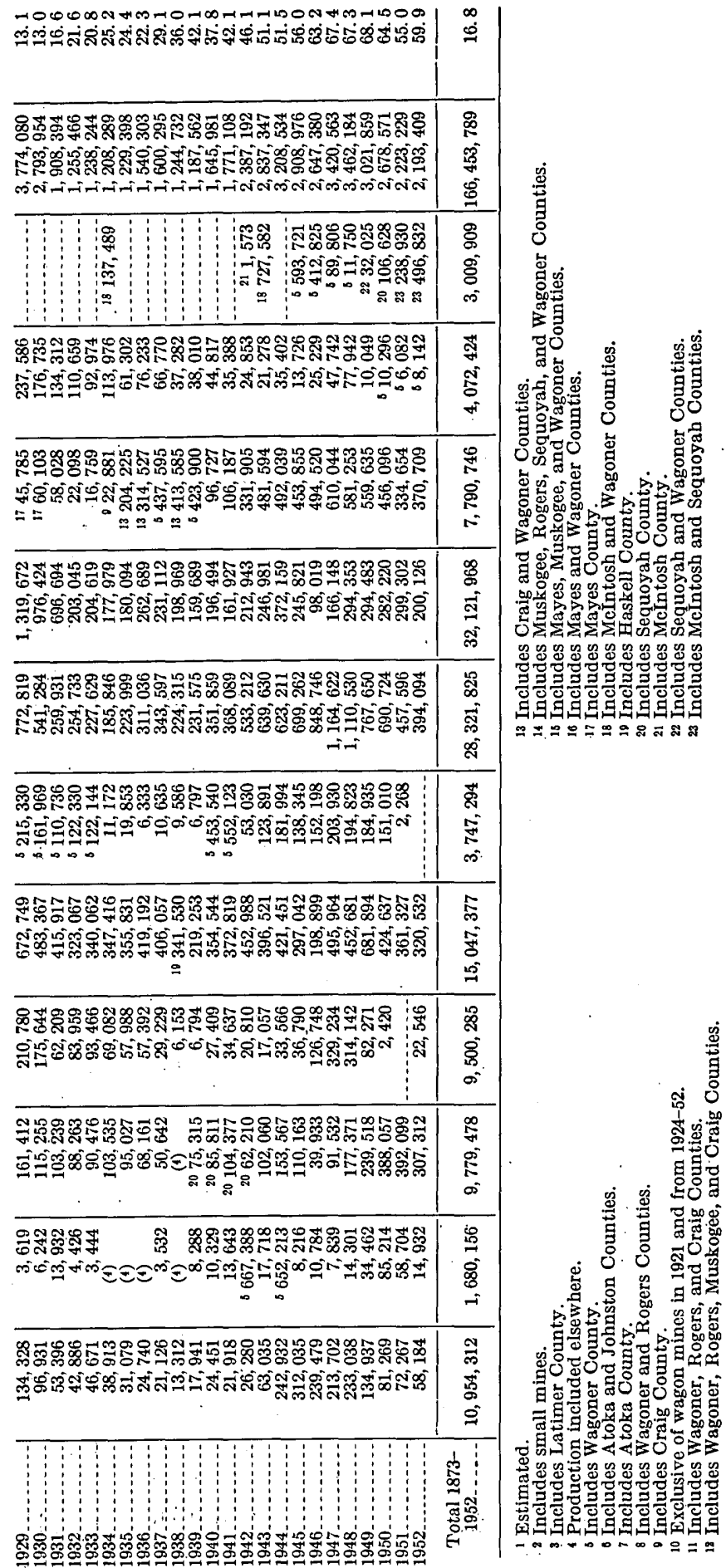


The predominant plan of underground mining in the State has been the room-and-pillar system, but numerous mines are now being operated on the panel system. Longwall mining was experimented with in various parts of the field in the early years, and has long been used in mining the relatively thin Cavanal bed on Poteau Mountain near Poteau, Le Flore County. An interesting system has been used for extracting the coal from one longwall mine in the Cavanal bed in this area. After undercutting, the coal is hauled out of the mine in large blocks, some weighing as much as 3 tons, by scow-pan and low flat mine cars. These blocks are broken into lump size with air hammers at the tipple, resulting in nearly 100 percent production of lump coal.

The average production of each of the 28 underground mines operating in Oklahoma in 1952 was 31,402 tons; the national average was 63,553 tons. Average production per man-day for the average number of 1,164 men employed at Oklahoma underground mines in 1952: was 4.03 tons; the national average was 6.39 tons. In the same year, 95.9 percent of the recorded underground production of coal in Oklahoma was mechanically cut, and 90.6 percent was mechanically loaded; in the entire nation, 95.1 percent was mechanically cut, and 75.6 percent was mechanically loaded.

Of the coal mined by both strip and underground methods in Oklahoma in 1952, 28.6 percent was mechanically cleaned in 5 operating plants; in the same year, 48.7 percent of total national production was mechanically cleaned.

\section{RECOVERABILITY IN MINING}

Only a part of the coal originally in place in a block of coal being mined can be delivered to the railroad car because of the normal losses: in mining and preparation: coal is lost in cutting, blasting, and handling; additional large quantities are left in pillars, roof, and floor; and more is lost in cleaning. Additional losses are apparent. when large areas of mining, including many individual mining operations, are considered: coal is left in barrier pillars between mines: and in beds unmined because of mining in other beds close above or below, and coal is lost in rolls, pinches, faults, and at shallow depth under streams, towns, and the like.

Losses such as these, considered over large areas of mining, are very highly variable, but the commonly used approximation of 50 percent loss, or 50 percent recoverability, mentioned by Averitt, Berryhill, and Taylor (1953, p. 12) seems to be a good average for the country as a whole. A detailed study of the Henryetta mining district in Okmulgee County, Okla. (Dunham and Trumbull, 1955), found that overall recoverability there for underground mining has been 50.5 percent. 
The geologic setting in which the coal beds of the southern part of the Oklahoma coalfield occur, however, is not so favorable for recovery as are conditions in the Henryetta district. Reporting on an examination made in 1915 of 59 mines in the southern part of the Oklahoma. coalfield, where most of the remaining reserves of coal in the State are located, Rutledge and Harrington (1918, p. 8) state: "In a few mines the recovery of the coal in the bed may be as much as 60 percent, although the usual proportion is about 50 , and in many mines is: as low as 45 per cent." Again, on page 9, they state that "Practically one ton of coal is left unmined, with great probability that it will never be recovered, for every ton mined." This recoverability applies to individual mining operations and does not take into account the additional losses between operations. Mining methods have, of course, been improved greatly since 1915 , notably by the trend toward substituting the panel system of mining for the room-and-pillar system: and by widespread mechanization, and therefore a greater recoverability than that mentioned above might be expected now and in the future.

Measurement and estimation of the areas which have been mined out and the areas of barrier pillars which have been left and will probably be left in future operations in Oklahoma, assuming an average barrier width between presently abandoned and commonly flooded: old mines and future new operations of 400 to 500 feet, reveal that about 427 million tons have been mined and lost in mining. Comparison of this figure with the total recorded production of 166.45 million tons leads to an overall recoverability figure of 39 percent for mining in Oklahoma to January 1, 1953.

The main factor which will undoubtedly cause difficulty in future mining in the southern part of the coalfield, in addition to the high dips in many places, is the flooding of many shallow mines around the edges of synclinal basins. In discussing the problem of recoverability, Rutledge and Harrington (1918, p. 8) state:

Many of the crop workings from which had been mined all the coal that could profitably be extracted *** have been abandoned and allowed to fill with water and gas, thus becoming a menace to adjoining mines and an almost insurmountable obstacle to mining below on the dip. The small mine has been the rule rather than the exception, and on some leases it was formerly customary to open one mine on each 40 -acre tract, and abandon the mine when the workings reached the boundary.

Exactly how much the presence of these abandioned and flooded or gas-filled mines up the dip of the coal beds from the great store of coal reserves lower in the synclinal basins will decrease recoverability there, because of the possibility of flooding an the consequent need. for extra-wide barrier pillars, remains to be seen.-. 
Although recoverability in strip mining is commonly far higher than that in underground mining, averaging perhaps 80 or 90 percent compared with 40 or 50 percent for underground mining, the part of the remaining coal reserves of Oklahoma which lies near enough to the surface to be stripped is extremely small. Consequently the higher recovery associated with strip mining cannot be expected materially to increase overall recoverability of the remaining coal reserves of the State.

\section{REFERENCES}

American Society for Testing Materials, 1939, Standard specifications for classification of coals by rank (A. S. T. M. Designation: D 388-38), in 1939 Book of A. S. T. M. Standards, pt. 3, p. 1-6: Philadelphia, Pa.

Averitt, Paul, Berryhill, L. R., and Taylor, D. A., 1953, Coal resources of the United States (a progress report, October 1, 1953) : U. S. Geol. Survey Circ. 293,49 p. [1954].

Berryhill, L. R., and Averitt, Paul, 1951, Coking-coal deposits of the western United States: U. S. Geol. Survey Circ. 90, 20 p.

Cade, C. M., 1953, The geology of the Marmaton group of northeastern Nowata and northwestern Craig Counties, Okla.: Tulsa Geol. Soc. Digest, v. 21, p. 130-148.

Chance, H. M., 1890, Geology of the Choctaw coal field: Am. Inst. Min. Eng. Trans. v. 18, p. 653-661.

Coal Age, 1953a, Stripping low-sulfur coal: Coal Age, v. 58, no. 4, p. 92-96. 1953b, Machine loading on long faces: Coal Age, v. 58, no. 6, p. 84-88.

Collier, A. J., 1907, The Arkansas coal field : U. S. Geol. Survey Bull. 326, 158 p.

Corps of Engineers, Department of the Army, 1951, The synthetic liquid fuel potential of Oklahoma, $231 \mathrm{p}$.

Dane, C. H., Rothrock, H. E., and Williams, J. E., 1938, Geology and fuel resources of the southern part of the Oklahoma coal field; part 3, The QuintonScipio district, Pittsburg, Haskell, and Latimer Counties : U. S. Geol. Survey. Bull. 874-C, p. 151-253.

Davis, J. D., and others, 1944, Carbonizing properties of Western region Interior province coals and certain blends of these coals: U. S. Bur. Mines Tech. Paper 667, $138 \mathrm{p}$.

Davis, J. D., and Reynolds, D. A., 1941, Carbonizing properties of McAlester bed coal from Atlas No. 2 mine, Henryetta, Okmulgee County, Okla.: Okla. Geol. Survey Mineral Rept. 12, 8 p.

- 1942, Carbonizing properties of McAlester bed coal from Dow No. 10 mine, Dow, Pittsburg County, Okla.: Okla. Geol. Survey Mineral Rept. 15, $10 \mathrm{p}$.

Drake, N. F., 1897, A geological reconnaissance of the coal fields of the Indian Territory : Am. Phiớs. Soc. Proc. v. 36, p. 326-419.

Dunham, R. J., and Trumbull, J. V. A., 1955, Geology and coal resources of the Henryetta mining diftrict, Okmulgee County, Okla. : U. S. Geol. Survey Bull. 1015-F, p. 183-223,

Eavenson, H. N., 1942, 'The first century and a quarter of American coal industry : Koppers Blidg., Pittsburgh, Pa., privately printed, $701 \mathrm{p}$.

Fitts, K. W. Jr., 1950, Dö Moines and older Pennsylvanian rocks of northeastern Oklahoma: Abuteng Sol. Soc., 1950 Field trip guidebook, 44 p. 
Fuller, M. L., 1920, Carbon ratios in Carboniferous coals of Oklahoma, and their relation to petroleum: Am. Assoc. Petroleum Geologists Bull., v. 15, p. 225-235.

Hendricks, T. A., 1935, Carbon ratios in part of the Arkansas-Oklahoma coal field: Am. Assoc. Petroleum Geologists Bull., v. 19, p. 937-947.

- 1937a, Geology and fuel resources of the southern part of the Oklahoma coal field, part 1, The McAlester district, Pittsburg, Atoka, and Latimer Counties: U., S. Geol. Survey Bull. 874-A, p. 1-90.

1937b, Pennsylvanian sedimentation in Arkansas coal field: Am. Assoc. Petroleum Geologists Bull., v. 21, p. 1403-1421.

- 1939, Geology and fuel resources of the southern part of the Oklahoma coal field, part 4, The Howe-Wilburton district, Latimer and Le Flore Counties: U. S. Geol. Survey Bull. 874-D, p. 255-300.

Hendricks, T. A., Dane, C. H., and Knechtel, M. M., 1936, Stratigraphy of Arkansas-Oklahoma coal basin: Am. Assoc. Petroleum Geologists Bull., v. 20 , p. $1342-1356$.

Hendricks, T. A., and Parks, Bryan, 1937, Geology and mineral resources of the western part of the Arkansas coal field: U. S. Geol. Survey Bull. 847-E, p. 189-224.

1950, Geology of the Fort Smith district, Arkansas: U: S. Geol. Survey Prof. Paper 221-E, p. 67-94.

Hendricks, T. A., and Read, C. B., 1934, Correlations of Pennsylvanian strata in Arkansas and Oklahoma coal fields: Am. Assoc. Petroleum Geologists Bull., v. 18, p. 1050-1058.

Hopper, The, 1954, Names of Oklahoma coal beds: v. 14, no. 8, p. 120-132, Norman, Okla.

Howe, W. B., 1951, Bluejacket sandstone of Kansas and Oklahoma: Am Assoc. Petroleum Geologists Bull., v. 35, p. 2087-2093.

Jewett, J. M., 1941, Classification of the Marmaton group, Pennsylvanian, in Kansas: Kans. State Geol. Survey Bull. 38, p. 285-344.

Kansas Geological Society, 1937, Guidebook 11th annual field conference, southeastern Kansas, northeastern Oklahoma, September 3-6, 108 p.

Knechtel, M. M., 1937, Geology and fuel resources of the southern part of the Oklahoma coal field, part 2, The Lehigh district, Coal, Atoka; and Pittsburg Counties: U. S. Geol. Survey Bull. 874-B, p. 91-149.

- 1949, Geology and coal and natural gas resources of northern Le Flore County, Okla.: Okla. Geol. Survey Bull. 68, 76 p.

Miser, H. D., 1954, Geologic map of Oklahoma: U. S. Geological Survey.

Moore, C. A., 1947, The Morrow series of northeastern Oklahoma: Okla. Geol. Survey Bull. 66, $151 \mathrm{p}$.

Moore, R. C., 1948, Classification of Pennsylvanian rocks in Iowa, Kansas, Missouri, Nebraska, and northern Oklahoma: Am. Assoc. Petroleum Geologists Bull., v. 32, p. 2011-2040.

1949, Divisions of the Pennsylvanian System in Kansas: Kans. State Geol. Survey Bull. 83, 204 p.

Moore, R. C., and others, 1951, The Kansas rock column: Kansas State Geol. Survey Bull. 89, $132 \mathrm{p}$.

Moose, J. E., and Searle, V. C., 1929, A chemical study of Oklahoma coals: Okla. Geol. Survey Bull. 51, 112 p.

Morgan, J. L., 1955, Spores of McAlester coal : Okla. Geol. Survey Circ. 36, 54 p.

Nuttall, Thomas, 1821, A journal of travels into the Arkansas Territory: Philadelphia, Pa., 296 p. 
Oakes, M. C., 1940, Geology and mineral resources of Washington County, Okla.: Okla. Geol. Survey Bull. 62, 208 p.

1944, Broken Arrow coal and associated strata: Okla. Geol. Survey Circ. $24,40 \mathrm{p}$.

- 1952, Geology and mineral resources of Tulsa County, Okla. : Okla. Geol. Survey Bull. 69, 234 p.

1953, Krebs and Cabaniss groups, of Pennsylvanian age, in Oklahoma: Am. Assoc. Petroleum Geologists Bull., v. 37, p. 1523-1526.

Oakes, M. C., and Jewett, J. M., 1943, Upper Desmoinesian and lower Missourian rocks in northeastern Oklahoma and southeastern Kansas: Am. Assoc. Petroleum Geologists Bull., v. 27, p. 632-640.

Oakes, M. C., and Knechtel, M. M., 1948, Geology and mineral resources of Haskell County, Okla.: Okla Geol. Survey Bull. 67, 134 p.

Pierce, W. G., and Courtier, W. H., 1937, Geology and coal resources of the southeastern Kansas coal field: Kans. State Geol. Survey Bull. 24, 122 p.

Rothrock, E. P., 1925, Geology of Cimarron County, Okla.: Okla. Geol. Survey Bull. 34, $110 \mathrm{p}$.

Rutledge, J. J., and Harrington, Daniel, 1918, Suggestions for improved methods of mining coal on Indian lands in Oklahoma: U. S. Bur. Mines Tech. Paper 154, $36 \mathrm{p}$.

Schoff, S. L., and Stovall, J. W., 1943, Geology and ground water resources of Cimarron County, Okla.: Okla. Geol. Survey Bull. 64, 317 p.

Scrutol, P. C., 1950, The petrography and environment of deposition of the Warner, Little Cabin, and Hartshorne sandstones in northeastern Oklahoma: Am. Jour. Sci., v. 248, p. 408-426.

Siebenthal, C. E., 1908, Mineral resources of northeastern Oklahoma: U. S. Geol. Survey Bull. 340, p. 187-228.

Shannon, C. W., and others, 1926, Coal in Oklahoma: Okla. Geol. Survey Bull. 4, 110 p. (Revised and edited by C. L. Cooper.)

Taff, J. A., 1901, Description of the Coalgate quadrangle, Oklahoma: U. S. Geol. Survey Geol. Atlas, folio 74, 6 p.

1902, The southwestern coal field: U. S. Geol. Survey 22d Ann. Rept., pt. 3, p. $367-413$.

- 1905, Progress of coal work in Indian Territory : U. S. Geol. Survey Bull. 260, p. $382-401$.

Taff, J. A., and Adams, G. I., 1900, Geology of the eastern Choctaw coal field, Indian Territory: U. S. Geol. Survey 21st Ann. Rept., pt. 2, p. 257-311.

Tomlinson, C. W., 1929, The Pennsylvanian system in the Ardmore Basin: Okla. Geol. Survey Bull. 46, 79 p.

United States Bureau of Mines, 1923-31, Mineral resources of the United States.

1928, Analyses of Oklahoma coals: U. S. Bur. Mines Tech. Paper 411, $62 \mathrm{p}$.

1932-52, Minerals Yearbooks.

1946. Typical analyses, bituminous coal produced in districts 12,14 , and

15 : U. S. Bur. Mines Data Book, v. 7, 74 p.

1954, Minerals Yearbook 1952: v. 2, Fuels, 450 p.

United States Congress Documents, 1910, Coal lands in Oklahoma : 61st Cong., $2 d$ sess., S. Doc. 390,374 p.

United States Geological Survey, 1882-93; 1900-1922, Mineral resources of the United States.

1894-99, 16th to 21st Annual reports. 
1935, Mine workings on segregated coal deposits, Choctaw and Chickasaw Nations in Oklahoma (19 parts; revised in recent years): On open file at U. S. Geol. Survey office, 509 S. 3d St., McAlester, Okla.

1945, Oklahoma water; prepared by the Water Resources Division, U. S. Geological Survey, for the Oklahoma Planning and Resources Board, $145 \mathrm{p}$. Wilson, C. W., Jr., and Newell, N. D., 1937, Geology of the Muskogee-Porum district, Muskogee and McIntosh Counties, Okla.: Okla. Geol. Survey Bull. $57,184 \mathrm{p}$.

TABLE 7.-Occurrence by bed, county, and rank, of coal included in estimate of the coal resources of Oklahoma

[H, M, L indicate high-, medium-, and low-volatile bituminous coal in bed and county indicated]

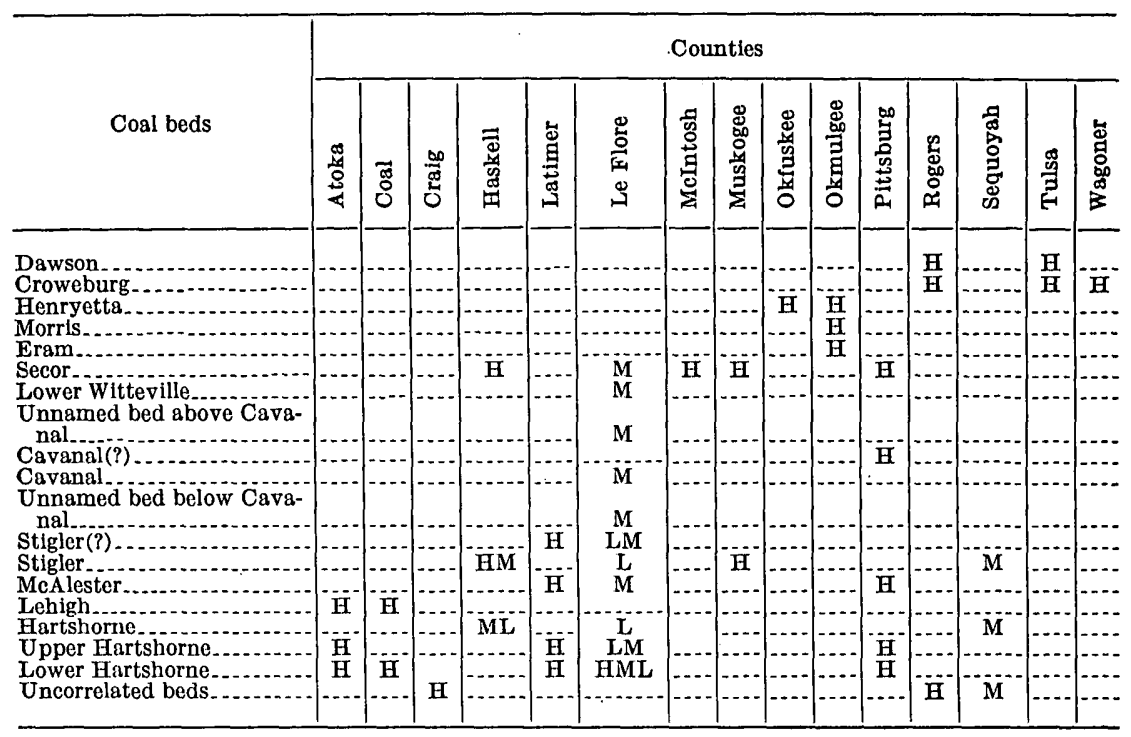




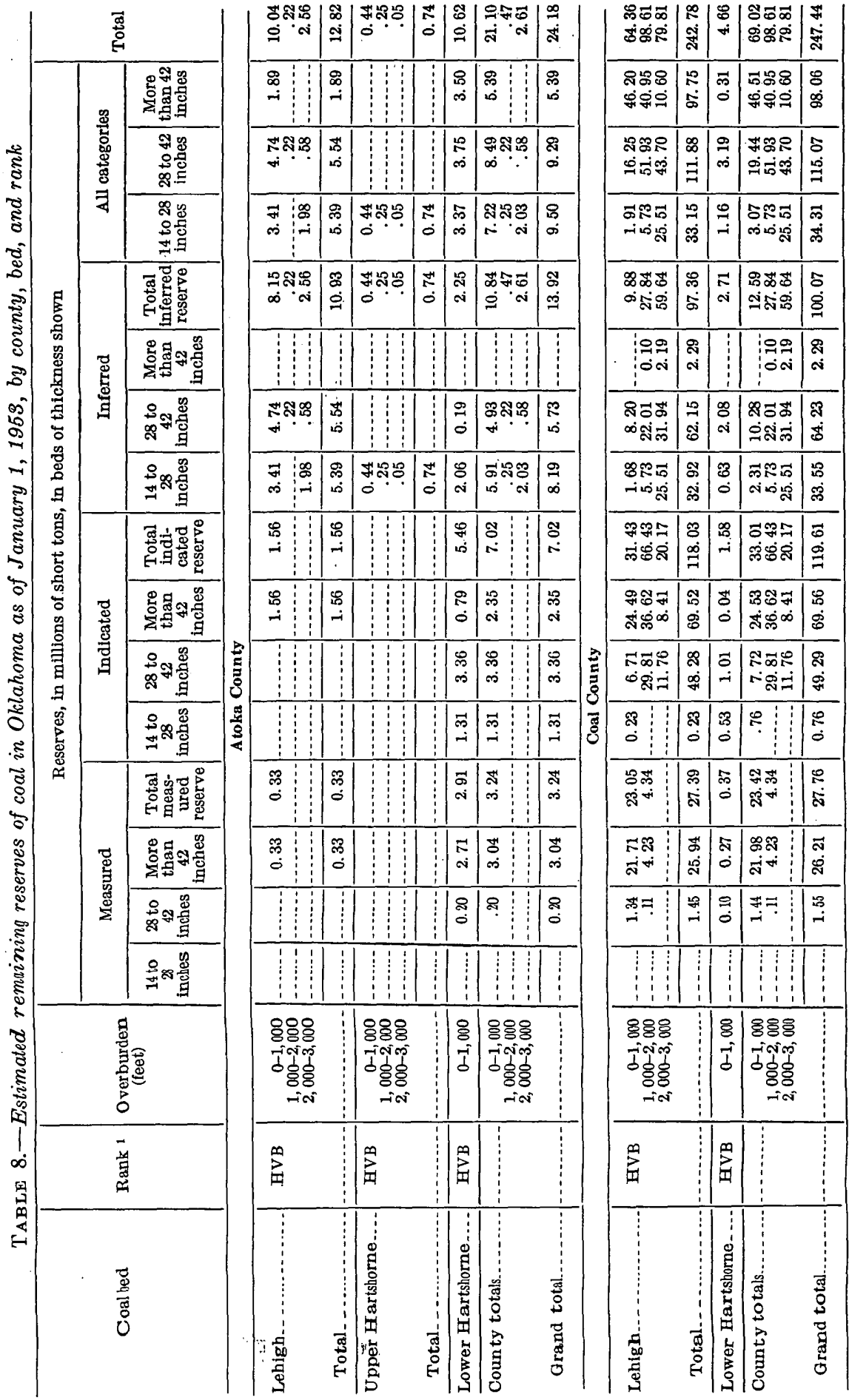




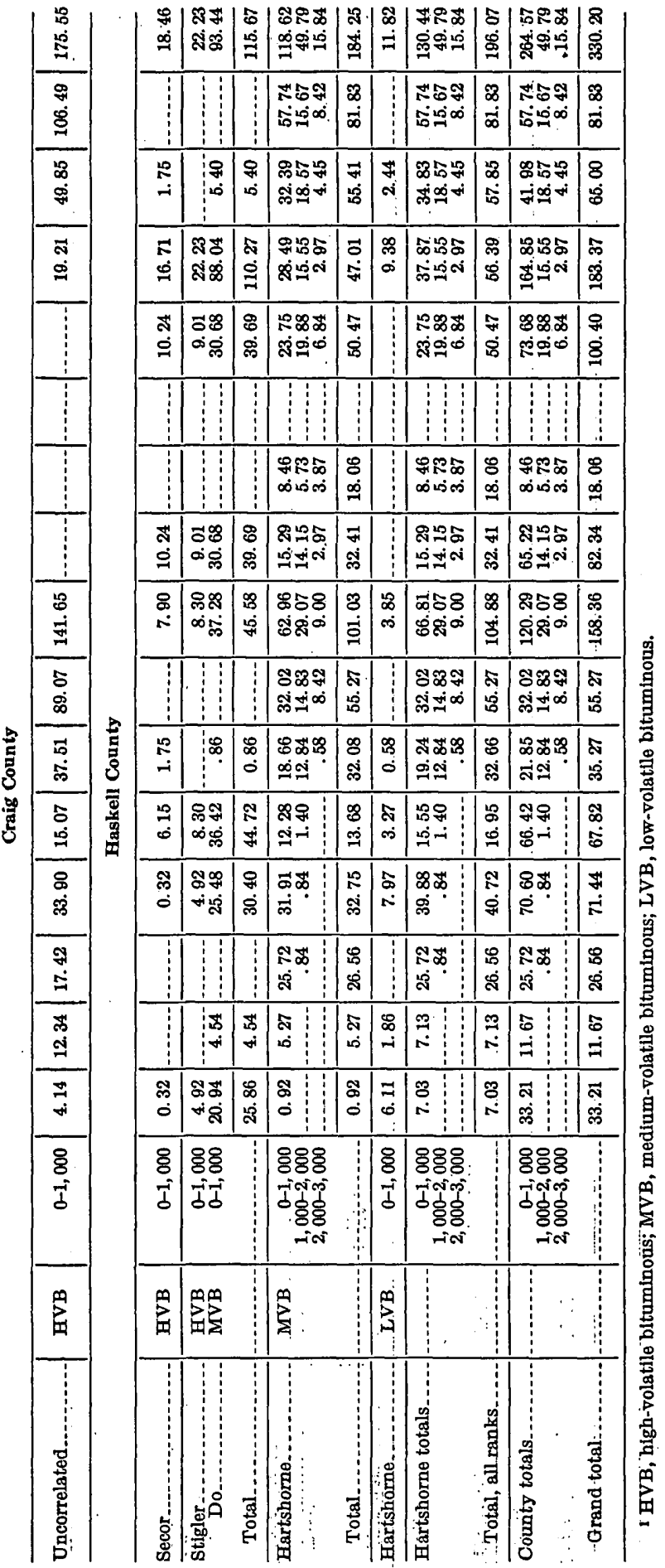




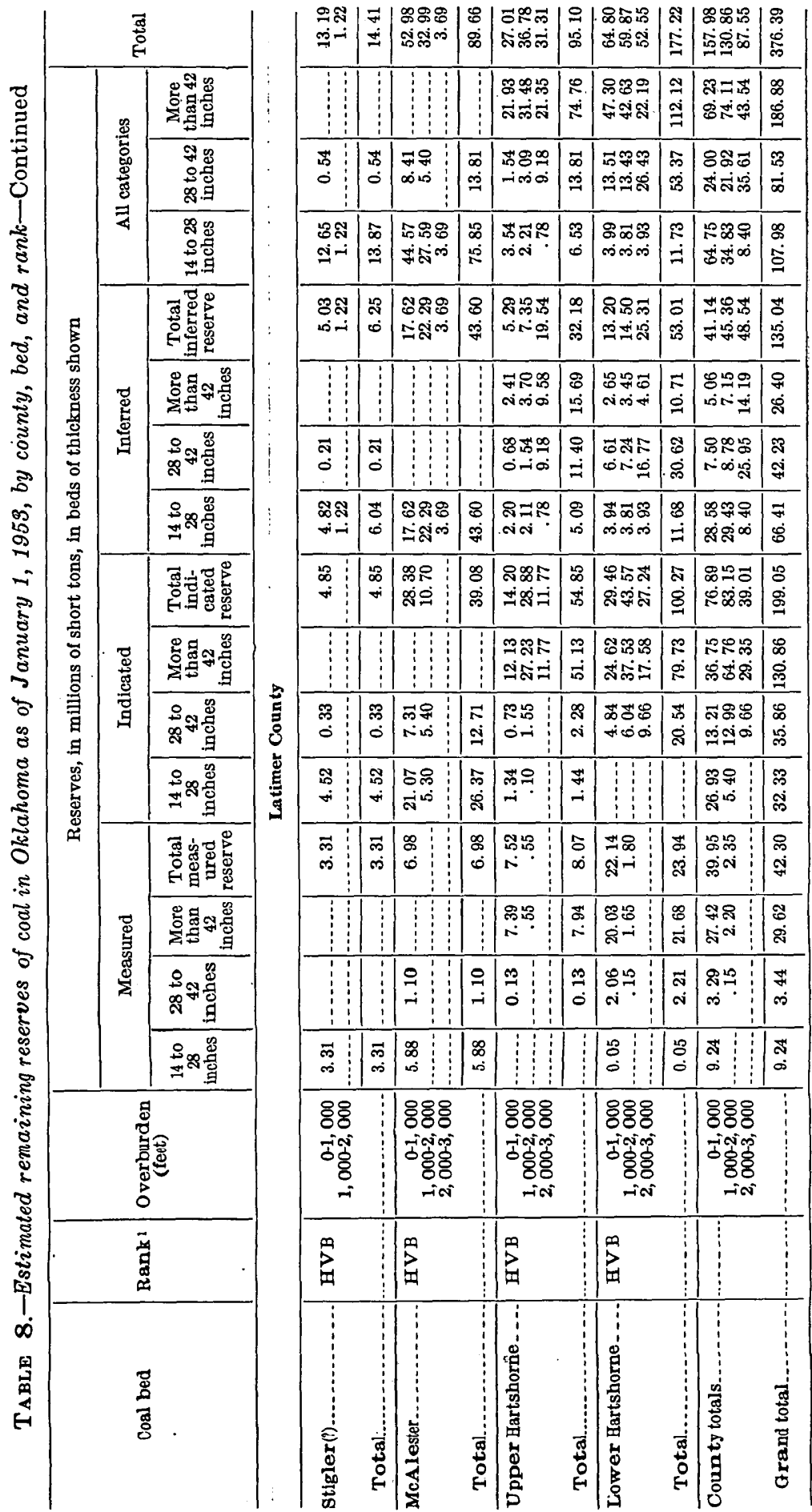




\begin{tabular}{|c|c|c|c|c|c|c|c|c|c|c|c|c|c|c|c|c|c|c|c|}
\hline 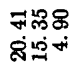 & $\begin{array}{l}8 \\
\dot{\sigma} \\
\dot{4}\end{array}$ & I9: & $\stackrel{8}{8}$ & $\begin{array}{l}\overrightarrow{\text { A }} \\
\text { ஸे }\end{array}$ & 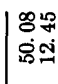 & $\begin{array}{l}\text { is } \\
\text { iิ }\end{array}$ & - & \% & 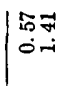 & $\stackrel{\infty}{\infty}$ & $\begin{array}{l}\infty \\
\infty \\
\infty\end{array}$ & 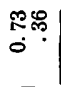 & 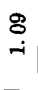 & 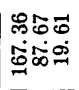 & . & $\overrightarrow{0}$ & $\begin{array}{l}\text { \& } \\
\stackrel{0}{0}\end{array}$ & 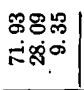 & 要 \\
\hline & 范 & & & & & & & & & & & & & 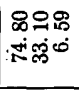 & & & & : & m. \\
\hline 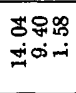 & ร & & & & $\stackrel{9}{\dddot{1}}$ & & & & & & & & & 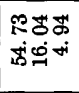 & $\begin{array}{l}F \\
\dot{8}\end{array}$ & & & 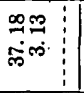 & के \\
\hline & 8 & 200 & $\stackrel{\text { ని }}{-}$ & $\begin{array}{l}\text { ন } \\
\text { के }\end{array}$ & 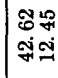 & & $\stackrel{8}{\circ}$ & 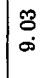 & 皇: & 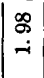 & $\begin{array}{l}\infty \\
\infty \\
\infty\end{array}$ & $\mid$ & $\stackrel{8}{-1}$ & 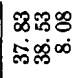 & $\begin{array}{l}\sharp \\
\dot{\infty} \\
\dot{\infty}\end{array}$ & $\mid \begin{array}{l}\infty \\
0 \\
0\end{array}$ & $\mid$\begin{tabular}{c}
$\infty$ \\
\multirow{0}{0}{} \\
0
\end{tabular} & $\begin{array}{l}\text { सक: } \\
\text { फंसंक }\end{array}$ & \begin{tabular}{|l}
4 \\
40 \\
8 \\
8
\end{tabular} \\
\hline $\begin{array}{l}\text { 雨 } \\
\text { Nim }\end{array}$ & $\begin{array}{l}8 \\
7\end{array}$ & 5 & : & $\begin{array}{l}\stackrel{8}{8} \\
\text { N }\end{array}$ & 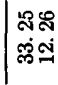 & & $\begin{array}{l}\vec{m} * \\
\dot{m}-1\end{array}$ & $\stackrel{8}{7}$ & 禺。 & 㝘 & ֻै. & 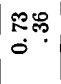 & $\begin{array}{c}8 \\
-1 \\
-1\end{array}$ & 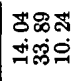 & $\begin{array}{l}7 \\
0 \\
0\end{array}$ & $\begin{array}{l}a= \\
0 \\
0\end{array}$ & Fit & 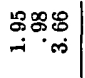 & 要 \\
\hline & & & & & & i & & & & 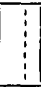 & & & & & & & & & \\
\hline 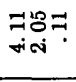 & ڤ్ & & 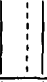 & & $\underset{\text { ส }}{+}$ & న & & & & 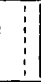 & & & & 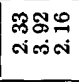 & $\begin{array}{l}7 \\
\infty\end{array}$ & & & & \\
\hline 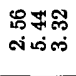 & 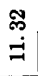 & $\begin{array}{l}5 \\
0 \\
0\end{array}$ & $\begin{array}{l}5 \\
0 \\
0\end{array}$ & $\begin{array}{l}\stackrel{\mathscr{B}}{\mathrm{i}} \\
\stackrel{\mathrm{N}}{ }\end{array}$ & 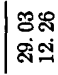 & & $\begin{array}{l}\vec{m} * \\
\infty-1\end{array}$ & $\stackrel{8}{\circ}$ & $\mid \begin{array}{c}0 \\
0 \\
0 \\
0\end{array}$ & $\begin{array}{l}5 \\
- \\
-i\end{array}$ & م. & 电 & $\stackrel{8}{8}$ & $\begin{array}{l}\infty \\
\alpha^{\infty} \infty \\
\phi^{\infty} \infty\end{array}$ & $\mid \begin{array}{l}0 \\
i \\
9 \\
j\end{array}$ & 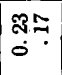 & 웅 & 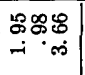 & 总 \\
\hline 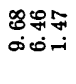 & $\stackrel{\overrightarrow{0}}{\stackrel{+}{二}}$ & 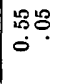 & $\begin{array}{l}8 \\
0 \\
0\end{array}$ & \%ั & 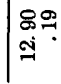 & $\begin{array}{l}8 \\
8 \\
9 \\
9\end{array}$ & $\begin{array}{l}\mathscr{E} \\
\text { i }\end{array}$ & $\begin{array}{l}\mathscr{8} \\
\text { i }\end{array}$ & ${ }^{\infty}=0$ & $\begin{array}{l}5 \\
0 \\
0\end{array}$ & $\stackrel{\circ}{\pi}$ & & & 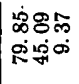 & 焉 & 文 & $\begin{array}{l}\infty \\
0 \\
0\end{array}$ & 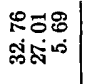 & $\begin{array}{l}9 \\
4 \\
8 \\
8\end{array}$ \\
\hline p & 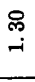 & & 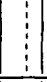 & & & 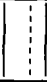 & & & & 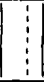 & & & & 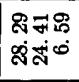 & $\mid \begin{array}{l}\text { \&i } \\
\text { of } \\
\text { in }\end{array}$ & & & & \\
\hline 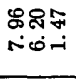 & $\begin{array}{l}8 \\
\stackrel{8}{-1} \\
\stackrel{1}{10}\end{array}$ & 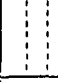 & 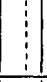 & & $\begin{array}{l}\Delta \\
\text { ஸे }\end{array}$ & $\begin{array}{l}\vec{N} \\
\dot{\infty}\end{array}$ & & & & 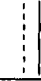 & & & & 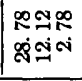 & 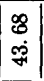 & & & & 节 \\
\hline & $\stackrel{8}{8}$ & & $\begin{array}{l}8 \\
0\end{array}$ & $\begin{array}{l}\text { कै } \\
\text { : }\end{array}$ & 89. & $\begin{array}{l}\infty \\
\infty \\
0 \\
0\end{array}$ & $\stackrel{\mathscr{S}}{\mathrm{s}}$ & $\begin{array}{l}8 \\
\text { i }\end{array}$ & $\mid \begin{array}{c}\infty \\
\substack{\infty \\
0 \\
0} \\
0\end{array}$ & के & I & & & & $\mid \begin{array}{l}\ddot{m} \\
\dot{m}\end{array}$ & $\begin{array}{l}\infty \\
0 \\
0\end{array}$ & $\stackrel{\circ}{\circ}$ & 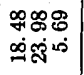 & 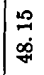 \\
\hline o & $\begin{array}{l}\text { if } \\
\text { if }\end{array}$ & : & : & & $\begin{array}{l}\mathscr{\%} \\
\dot{m}\end{array}$ & $\begin{array}{l}\mathscr{\wp} \\
\infty \\
\infty\end{array}$ & $\stackrel{\vec{m}}{-}$ & $\stackrel{m}{-1}$ & & & & & & \begin{tabular}{l}
58 \\
\multirow{2}{*}{$\infty$}
\end{tabular} & $\begin{array}{l}\stackrel{9}{1} \\
\dot{\infty} \\
\infty\end{array}$ & & & $\begin{array}{l}\text { ๙ิ오 } \\
\dot{m}\end{array}$ & 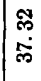 \\
\hline & హె & & 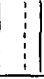 & & & & & & & & & & & & $\mid \begin{array}{l}80 \\
\text { if } \\
\text { if }\end{array}$ & & & & के \\
\hline & $\stackrel{\oplus}{\oplus}$ & & 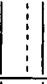 & & & & & & & & & & & $\begin{array}{l}\tilde{0} \\
\tilde{3}\end{array}$ & 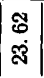 & & & $\begin{array}{l:}80 \\
\text { జิ }\end{array}$ & $\begin{array}{l}8 \\
\text { ๙ุ }\end{array}$ \\
\hline & & $\begin{array}{l}\text { : } \\
\text { : } \\
0\end{array}$ & : & & $\begin{array}{l}ஜ \\
\oplus\end{array}$ & $\begin{array}{l}\circledast \\
\ddot{m}\end{array}$ & $\vec{m}$ & क् & & & & & & 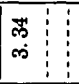 & $\mid \begin{array}{l}m \\
m \\
\dot{m}\end{array}$ & & & 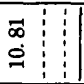 & $\mid \begin{array}{l}\infty \\
\infty \\
0\end{array}$ \\
\hline 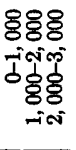 & & 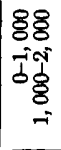 & & $\frac{8}{j}$ & हీ요 & & 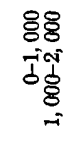 & & $\begin{array}{l}\text { 양ㅇ } \\
\text { jँ }\end{array}$ & & $\begin{array}{l}0 \\
\bar{d}\end{array}$ & 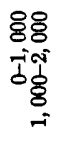 & & 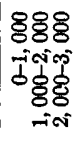 & & 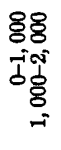 & & 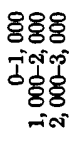 & \\
\hline & 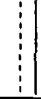 & $\sum_{\Sigma}^{\infty}$ & & $\sum_{i}^{\infty}$ & 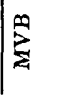 & & $\sum_{i}^{\infty}$ & & 鼠罢 & & $\sum_{-1}^{\infty}$ & & & & & & & & \\
\hline & 西 & 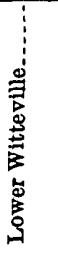 & 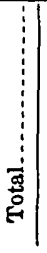 & 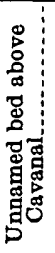 & 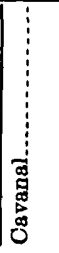 & 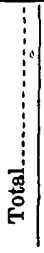 & 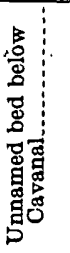 & क्ष & 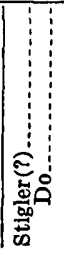 & . & 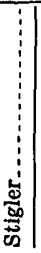 & 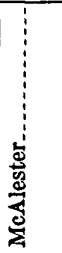 & ؛ & 递 & 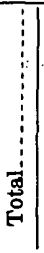 & 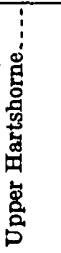 & $\begin{array}{c}\vdots \\
\vdots \\
\vdots \\
\vdots \\
\vdots \\
\vdots \\
\vdots \\
050 \\
0 \\
0\end{array}$ & 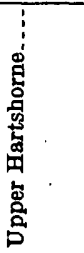 & 离 \\
\hline
\end{tabular}




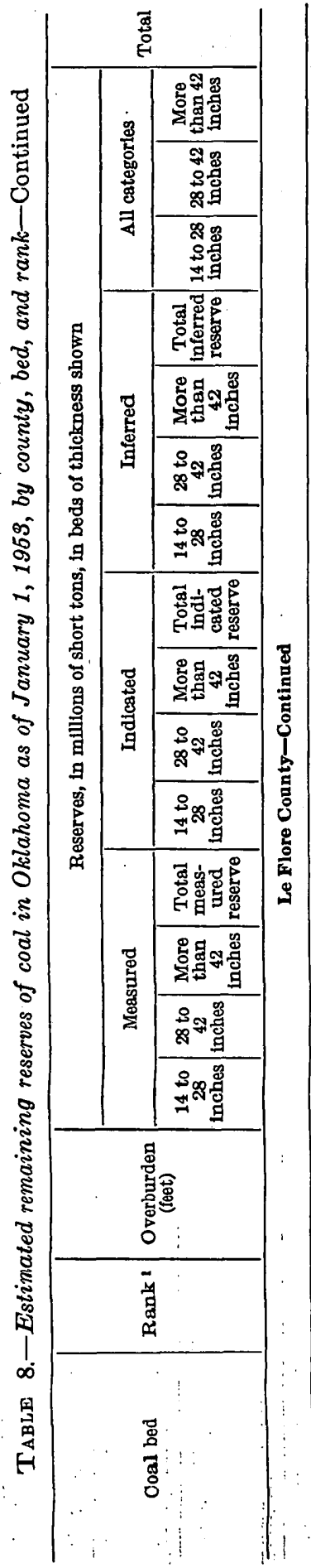

\begin{tabular}{|c|c|c|c|c|c|c|c|c|c|c|c|}
\hline $\begin{array}{l}\text { సేజి } \\
\text { నిజిం }\end{array}$ & $\begin{array}{l}18 \\
8 \\
8\end{array}$ & 풍 & $\begin{array}{l}2 \\
0 \\
0\end{array}$ & 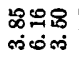 & $\begin{array}{l}\text { का } \\
\text { m }\end{array}$ & 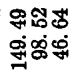 & 总 & 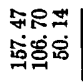 & $\mid \begin{array}{c}-m \\
\vec{m} \\
\dot{m}\end{array}$ & 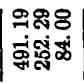 & 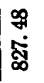 \\
\hline 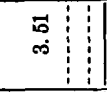 & $\begin{array}{l}50 \\
\text { is }\end{array}$ & $\begin{array}{l}8 \vec{\Phi} \\
\text { के - }\end{array}$ & 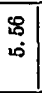 & & 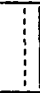 & \begin{tabular}{l|} 
DొL \\
ర్లేత
\end{tabular} & $\begin{array}{l}\mathscr{m} \\
\tilde{g} \\
\dot{g}\end{array}$ & $\begin{array}{l}\text { fक्ष } \\
\text { 요며 }\end{array}$ & $\begin{array}{l}\overrightarrow{5} \\
\dot{0}\end{array}$ & 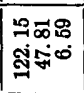 & $\begin{array}{l}18 \\
08 \\
01 \\
71\end{array}$ \\
\hline 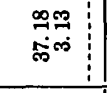 & $\begin{array}{l}\overrightarrow{5} \\
\dot{+}\end{array}$ & $\stackrel{\infty}{\stackrel{\infty}{0}=}$ & $\begin{array}{c}8 \\
\stackrel{\circ}{\circ} \\
0\end{array}$ & 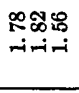 & $\stackrel{9}{2}$ & 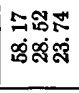 & 悉 & 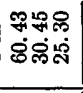 & $\left|\begin{array}{l}\infty \\
\stackrel{\sim}{二} \\
=\end{array}\right|$ & 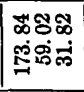 & \& \\
\hline 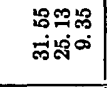 & $\begin{array}{l}8 \\
8 \\
8\end{array}$ & $\begin{array}{l}\vdots \\
\vdots \\
\vdots \\
\vdots \\
\end{array}$ & & 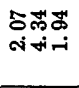 & $\infty$ & 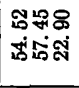 & $\mid \begin{array}{l}\infty \\
\infty \\
\dot{D}\end{array}$ & 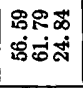 & 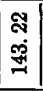 & 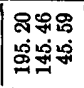 & $\begin{array}{l}\text { å } \\
\infty \\
\text { : }\end{array}$ \\
\hline 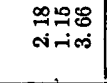 & $\begin{array}{l}\mathscr{8} \\
\infty\end{array}$ & & & 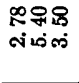 & $\begin{array}{l}\infty \\
- \\
=\end{array}$ & 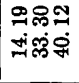 & $\begin{array}{l}-1 \\
\dot{\infty}\end{array}$ & 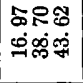 & $\begin{array}{l}\mathscr{R} \\
8 \\
\end{array}$ & 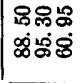 & ำ \\
\hline & 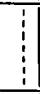 & \begin{tabular}{l|l} 
\\
$\vdots$ \\
1
\end{tabular} & $\begin{array}{c}\vdots \\
\vdots \\
\vdots \\
\vdots\end{array}$ & & $\begin{array}{l}1 \\
\vdots \\
\vdots \\
\vdots\end{array}$ & is: & $\stackrel{N}{\stackrel{0}{0}}$ & \begin{tabular}{l:}
\multirow{1}{*}{} \\
0 \\
0
\end{tabular} & $\stackrel{2}{\circ}$ & \begin{tabular}{l}
\multirow{2}{*}{$!$} \\
\end{tabular} & 胥 \\
\hline & 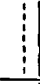 & $\begin{array}{r:}\vdots \\
\vdots \\
\vdots \\
\vdots \\
\end{array}$ & $\begin{array}{l}\vdots \\
\vdots \\
1 \\
1\end{array}$ & 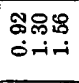 & 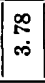 & 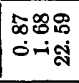 & $\begin{array}{l}\overrightarrow{4} \\
\stackrel{2}{*}\end{array}$ & 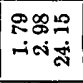 & 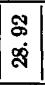 & 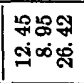 & 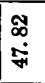 \\
\hline 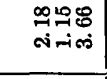 & $\begin{array}{c}8 \\
0 \\
0\end{array}$ & $\begin{array}{r:}\vdots \\
\vdots \\
\vdots \\
\vdots \\
\end{array}$ & & 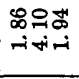 & \begin{tabular}{l}
8 \\
\hdashline \\
-2
\end{tabular} & 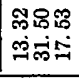 & 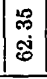 & 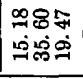 & 象 & 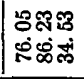 & 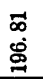 \\
\hline 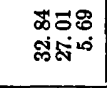 & $\begin{array}{l}80 \\
18\end{array}$ & $\begin{array}{l}\text { 유음 } \\
\text { if }\end{array}$ & $\begin{array}{l}8 \\
\text { o }\end{array}$ & S: & $\begin{array}{l}\mathscr{\infty} \\
-i\end{array}$ & 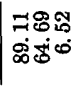 & 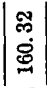 & 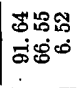 & $\begin{array}{l}\overrightarrow{5} \\
\text { सें }\end{array}$ & 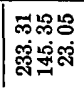 & 혐 \\
\hline & 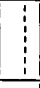 & ஃ̊. & 占 & & $\begin{array}{c}\vdots \\
\vdots \\
\vdots \\
\end{array}$ & \begin{tabular}{l|l} 
क뇨 \\
సं.
\end{tabular} & भ̊ & 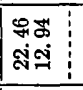 & 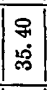 & 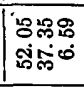 & $\begin{array}{l}8 \\
10 \\
18\end{array}$ \\
\hline 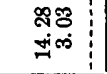 & $\vec{~}$ & 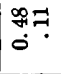 & $\begin{array}{l}0 \\
0 \\
0\end{array}$ & \begin{tabular}{l|}
$\infty$ \\
$\infty$
\end{tabular} & 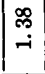 & 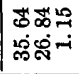 & $\begin{array}{l}\mathscr{E} \\
\ddot{8}\end{array}$ & 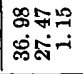 & $\begin{array}{l}8 \\
8 \\
8\end{array}$ & 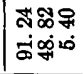 & $\begin{array}{l}\text { 9 } \\
\text { : } \\
\text { g }\end{array}$ \\
\hline 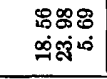 & $\begin{array}{l}\mathscr{W} \\
\mathscr{q}\end{array}$ & $\begin{array}{l:}\vdots \\
\vdots \\
\vdots \\
\vdots \\
\vdots\end{array}$ & 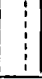 & \begin{tabular}{l|l} 
సีనี \\
:
\end{tabular} & 웅 & 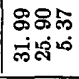 & $\begin{array}{l}\mathscr{~} \\
\text { ஜ் }\end{array}$ & 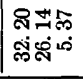 & $\ddot{8}$ & 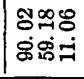 & $\begin{array}{l}\text { व̊ } \\
0 \\
0 \\
0 \\
0\end{array}$ \\
\hline $\begin{array}{l}\text { สิำ } \\
\text { ผึ่ }\end{array}$ & బิ & 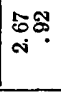 & $\begin{array}{l}8 \\
\text { i⿱ } \\
\text { is }\end{array}$ & & 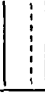 & $\mid \begin{array}{l}9 \% \\
\text { की }\end{array}$ & 帘 & 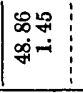 & 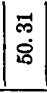 & 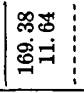 & 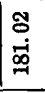 \\
\hline \begin{tabular}{l|l}
$\vec{n}$ & \\
$\dot{\infty}$ & \\
\end{tabular} & $\begin{array}{l}\text { है } \\
\text { के }\end{array}$ & $\begin{array}{l}\text { ธ్ర. } \\
\text { ํ. }\end{array}$ & $\begin{array}{l}8 \\
0 \\
\text { is }\end{array}$ & & 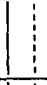 & 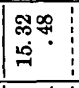 & $\mid \begin{array}{l}80 \\
2 \\
2\end{array}$ & \begin{tabular}{|l|}
8 \\
\multirow{2}{*}{-1}
\end{tabular} & $\begin{array}{l}\text { 吕 } \\
\text { Ф્త }\end{array}$ & 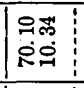 & 吉 \\
\hline \begin{tabular}{l:} 
\&ి으 \\
\hdashline สิ
\end{tabular} & $\begin{array}{l}8 \\
\text { ฌุ }\end{array}$ & $\begin{array}{l}\vdots \\
\vdots \\
\vdots \\
\vdots\end{array}$ & & & 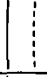 & \begin{tabular}{|l|l}
8 & \\
$\vec{A}$ & \\
\end{tabular} & $\begin{array}{l}8 \\
\dot{\text { ले }}\end{array}$ & \begin{tabular}{|l:l}
8 & \\
$\dot{A}$ & \\
\end{tabular} & $\mid \begin{array}{l}\mathscr{8} \\
\text { ส่ }\end{array}$ & 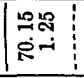 & 㝵 \\
\hline \begin{tabular}{l|l}
$\infty$ & \\
0 & \\
0 & \\
& \\
\end{tabular} & $\begin{array}{l}\infty \\
\infty \\
0\end{array}$ & $\begin{array}{r:} \\
\vdots \\
1 \\
1 \\
1 \\
1 \\
\end{array}$ & $\begin{array}{c}\vdots \\
\vdots \\
\vdots \\
\end{array}$ & & 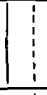 & \begin{tabular}{|l|} 
สิด \\
$\infty$
\end{tabular} & $\mid \begin{array}{l}\stackrel{2}{N} \\
\infty\end{array}$ & $\begin{array}{l:l}\text { N.t요 } \\
\infty^{\circ}\end{array}$ & 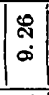 & \begin{tabular}{|l|l|} 
mथ \\
के \\
\end{tabular} & $\begin{array}{l}\infty \\
-1 \\
\dot{d}\end{array}$ \\
\hline 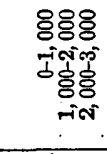 & $\begin{array}{l}\vdots \\
\vdots \\
\vdots \\
\vdots \\
\vdots\end{array}$ & 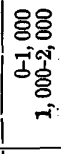 & & 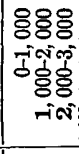 & & 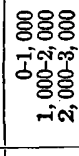 & 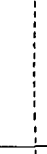 & 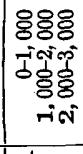 & 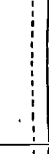 & 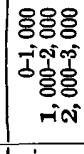 & \\
\hline & $\begin{array}{l}3 \\
\vdots \\
\end{array}$ & $s^{9}$ & & $\sum_{i}^{\infty}$ & 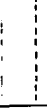 & $\stackrel{n}{\stackrel{n}{H}}:$ & & & 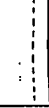 & & \\
\hline 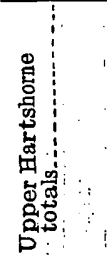 & 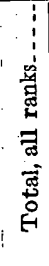 & 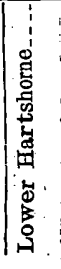 & 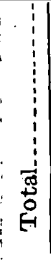 & 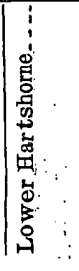 & 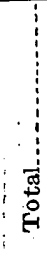 & 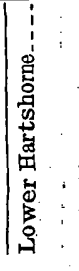 & $\begin{array}{r}1 \\
\vdots \\
\vdots \\
\vdots \\
0 \\
0 \\
0 \\
0 \\
0 \\
0 \\
0\end{array}$ & 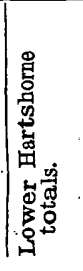 & 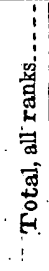 & 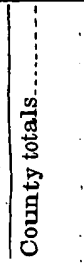 & . \\
\hline
\end{tabular}


$\because$ COAL RESOURCES OF OKLAHOMA

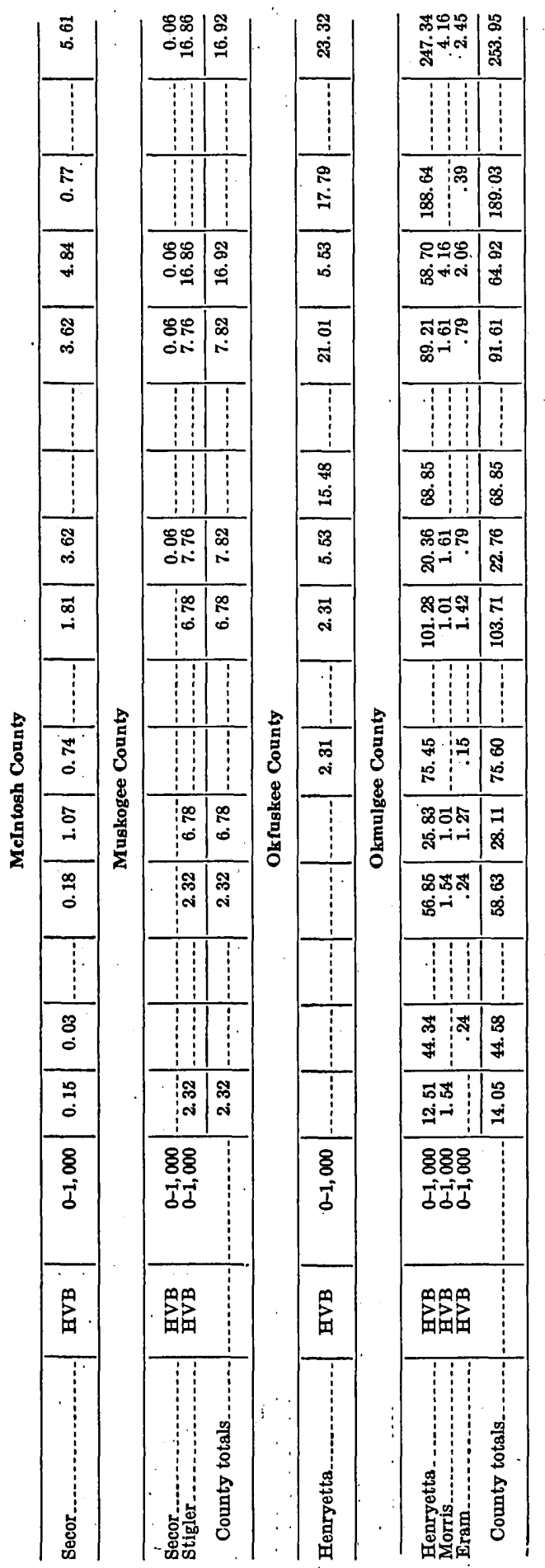




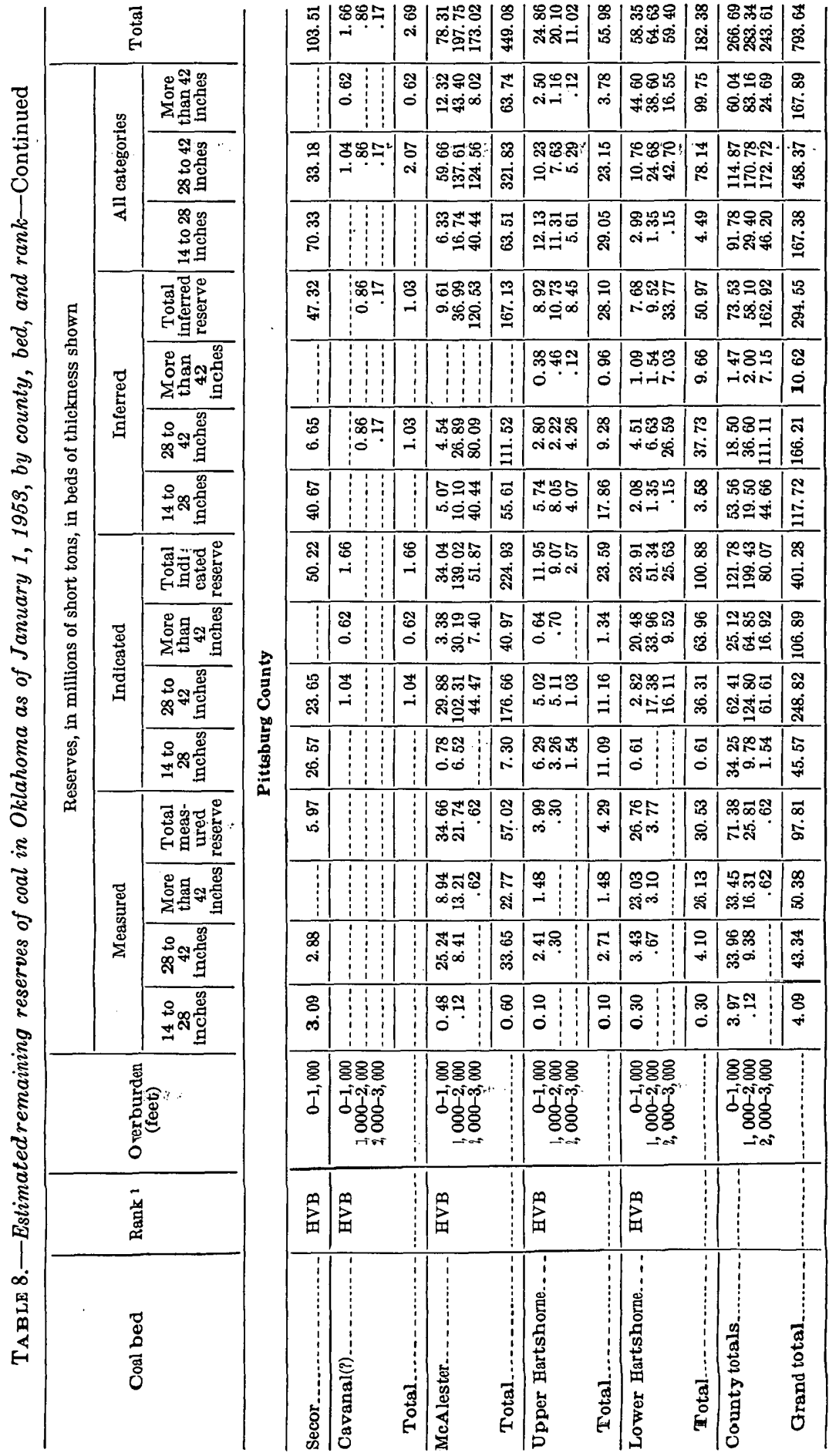




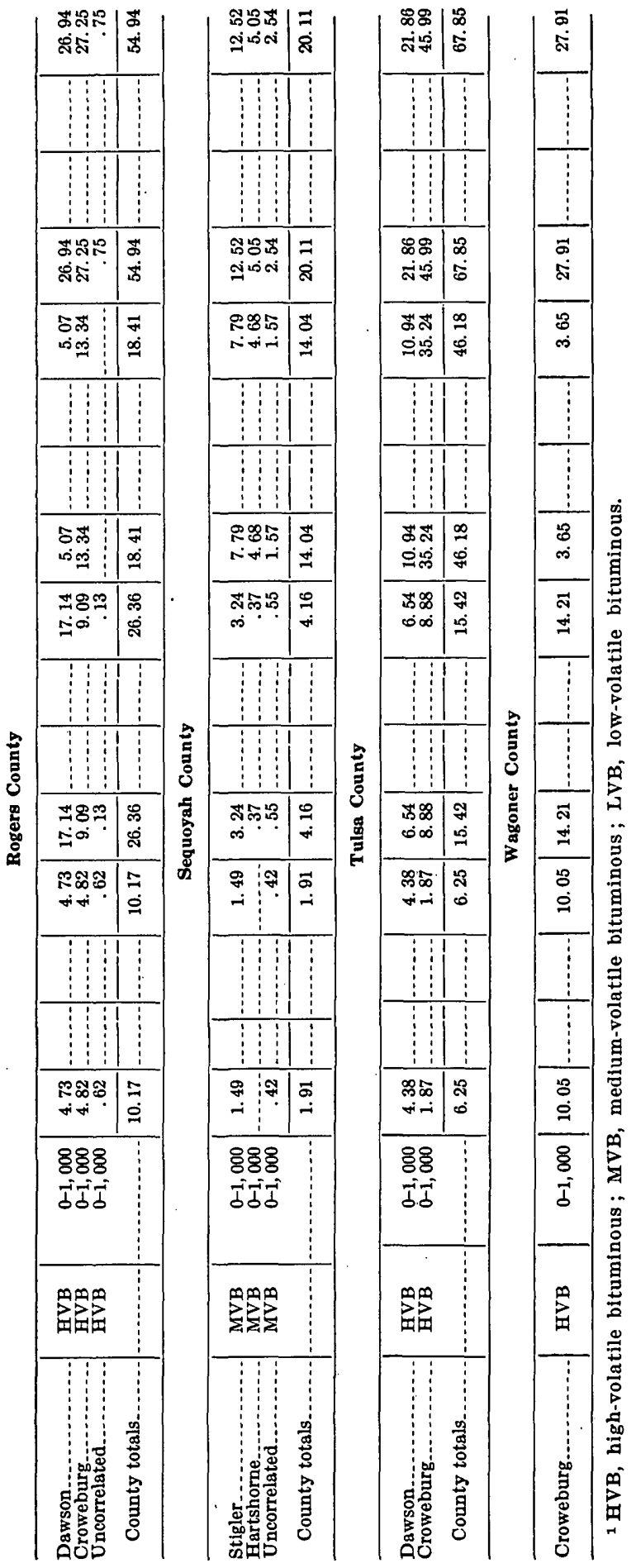





\section{INDEX}

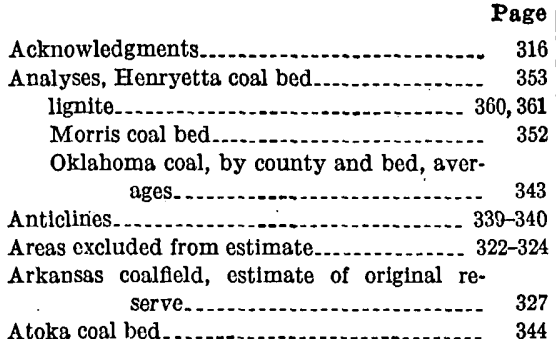

Atoka coal bed......... 344

Backbone anticline.................. 331, 340, 344, 346

Bellamy coal bed.............................. 355

Bovier coal bed ................................... 35 ?

Blocker coal bed................................. 351

Bloyd shale, coal in............................ 332

Boggy formation....................... 334-335, 351

Bluejacket sandstone member....... 334, 337, 350

Inola limestone member................... 335

Bokoshe syncline................................ 332

Brazil anticline........................... 332, 347, 348

Broken Arrow coal bed................. 356-357; pl. 17

Cabaniss group...... 331, 335, 336, 337, 339, 355, 356, 357

Calculation, reserve estimates. .......... 318, 321-322 tonnage estimates..................... 321-322

Calvin sandstone.............................. 337

Campbell, M. R., estimate of coal resources of Oklahoma................... 324-326

Carbon fault

Carter County, coal ........................... 359-360

Cavanal coal bed.................... 334, 349-350, 366

Oavanal syncline............................. 334, 348

Cedar Bluff coal bed........................ 339, 359

Chanute formation ......................... 339

Checkerboard limestone........................ 339

Cherokee coal bed ............................ 355

Cherokee formation......................... 333, 336

Cherokee group............................. 354, 357

Choctaw thrust fault........................ 340

Cimarron County, lignite.................. 360-361

Classification of coals by rank.............. 317-318

Coal beds, Henryetta mining district....... 351-354 northeastern Oklahoma................. 354-359 southern part of Oklahoma coalffeld... 341-351;

, pl. 16

Coalgate anticline...................................... 346

Coffeyville formation ........................ 339, 359

Corps of Engineers, estimate of coal resources of Oklahoma................... 326-327

Crowder coal bed............................. 351

Croweburg (Broken Arrow) coal bed......... 322, $325,337,354,356-357$; pl. 17

Dawson coal bed. 325,
Page

Dewey formation............................ 339

Dip of the beds. See Structure.

Drainage...................................... 329

Drywood (Bellamy) coal bed................ 355

Eram coal bed

$336,351-352$

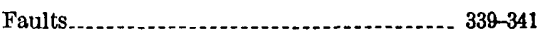

Fleming coal bed.......................... 356

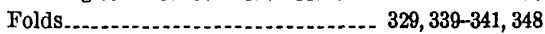

Fort Scott coal bed......................... 357

Fort Scott limestone.............. 336, 337, 357; pl. 16

Geologic information, status................. 322-324

Hartshorne coal bed.................. 324, 332, 344-345

Hartshorne sandstone....... 331, 332, 336, 340, 343, 345

Hartshorne syncline......................... 344

Henryetta coal bed........................... 323 , $325,336,352,353-354,356 ;$ pl. 17

Henryetta mining district................... 316 ,

$341,351-354,362,363,366-367$

Henryetta-Schulter faulted anticline.......... 341, 353; pl. 17

Hogshooter limestone.............................. 339

Holdenville shale............... 337, 339

Indian lands, segregated................... 326

Indtcated reserves, definition............... 319-320

Inferred reserves, definition ................... 320

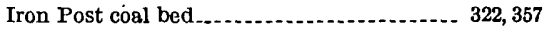

Jones Creek coal bed........................ 351

Kiowa syncline.................................. 351

Krebs group ........ 331, 333, 336, 337, 340, 355, 356, 357

Krebs syncline................................ 351

Labette shale.................................. 387

Lehigh coal bed . . . . . . .

Lehigh mining district....................... 344, 346

Lehigh syncline.............................. 344, 346

Lenapah limestone............................ 337

Lexington coal bed............ 339, 358

Lignite in Cimarron County ................ 360-361

Location of Oklahoma coalfield.......... 309, 327-329

Lone Star anticline............................. 331

Lower Hartshorne coal bed....... 332, 341-345; pl. 17

Lower Witteville coal bed................. 335, 350

McAlester formation........ 331, 332-334, 345, 346, 349 Cameron sandstone member............... 334

Keota sandstone member................... $\quad 334$

Lequire sandstone member................ 334

Little Cabin sandstone member..... 333, 337, 355

McCurtain shale member................ 333-334

Tamaha sandstone member.............. 334

Warner sandstone member.. 333, 337, 355; pl. 16

McAlester (Lehigh) coal bed................. 324, 334, 341, 346-347; pl. 17 
Mapping of coalfeld area.

322-324 Sansbois syncline 334,351

Marmaton group......................... 337, 339

Massey cosal bed............................ 351

Measured reserves, definition............... 319

Methods of estimating reserves............ 316-322

Milton anticline..................... 331, 340, 344, 348

Mineral coal bed............................ 356

Mining methods.......................... 363, 366

Morris coal bed.............. 32 _. $323,336,352$

Morrow group................................ 337

Mulky coal bed..................... 357

Nelle Bly formation . . . . .

Northeàstern Oklahoma, coal beds. ........ 354-359.

Nowata shale................................ 337

Oklahoma coalfleld, general information .... 327-330

Oologah limestone......................... 337

Pawpaw coal bed

Penitentiary fault. . . . .

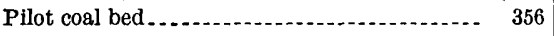

Population ................................... 330

Precipitation

Production of coal.

Purpose of report.............. 308

Quinton coal bed......................... 351

Rank of coal, determination ........... 317-318

Recoverability in mining . . . . . .

Relief. . . . . . . . . .

Reserves, distinction between measured, indicated, and inferred............ 319-320

distinction between original, remaining, and recoverable................ 320-321

distribution........................... 311

estimated remaining, Jan. 1, 1953....... 372-379

methods of estimating. ................. $316-322$

summary of estimated............... 309, 312 -314

Riverton coal bed . .

Rowe coal bed............................ 350, 355

Savanns anticline .

Savanna formation. ............ 331, 334, 349, 350; pl. 16

Spaniard limestone member............ 334, 337

Secor coal bed.

Seminole formation ....................... 339

Senora formation ....................... 331, 335-336

Breezy Hill limestone member............. $\quad 357$

Chelsea sandstone member.............. $\quad 337$

Verdigris limestone member.............. $\quad 337$

Source of information

Stigler coal bed.................... 334, 346, 347-348

Stigler(?) coal bed...... . . . . . . . . . . . . . . $348-348$

iStratigraphy, northern part of Oklahoma coalfield. . ................. 336-339; pl. 16 southern part of Oklahoma coalfield.... 330-336;

pl. 16

Structure, northern part of Oklaboma coalfield............................. 341

southern part of Oklahoma coalfield .... 339-340 Stuart shale...................... 331, 335, 336, 351 Synclines............................... 329, 339-340

Temperatures.............................. 329-330

Thayer coal bed.......................... 359

Thickness of beds........ 318-319

Thickness of overburden. . . . . . . . . . . 319

Thurman sandstone................. 331, 335, 336, 351

Tonnage estimates, calculation . . . . . . . . . . $321-322$

Topography ...

Transportation........................... 330, 361

Tulsa coal bed............................. 358-359

Upper Hartshorne coal bed.......... 332, 344, 345-346

Upper Witteville coal bed.................. 335, 351

Uses of coal............................ 345, 348, 363

Weight of coal................................ 318

Weir-Pittsburg coal bed............... 355, 357-358

Wetumka shale_............................ 337

Wewoka formation ......................... 337 